\title{
Relations of Streamflow and Specific- Conductance Trends to Reservoir Operations in the Lower Arkansas River, Southeastern Colorado
}

By Michael E. Lewis and Daniel L. Brendle

U.S. GEOLOGICAL SURVEY

Water-Resources Investigations Report 97-4239

Prepared in cooperation with the COLORADO SPRINGS UTILITIES;

PUEBLO BOARD OF WATER WORKS;

SOUTHEASTERN COLORADO WATER CONSERVANCY DISTRICT;

PUEBLO COUNTY, DEPARTMENT OF PLANNING AND DEVELOPMENT;

CITY OF AURORA, DEPARTMENT OF UTILITIES;

ST. CHARLES MESA WATER DISTRICT;

UPPER ARKANSAS AREA COUNCIL OF GOVERNMENTS;

UPPER ARKANSAS WATER CONSERVANCY DISTRICT;

CITY OF PUEBLO, DEPARTMENT OF UTILITIES;

PUEBLO WEST METROPOLITAN DISTRICT;

FREMONT SANITATION DISTRICT;

CITY OF ROCKY FORD; CITY OF LAS ANIMAS; AND CITY OF LAMAR

Denver, Colorado

1998 


\title{
U.S. DEPARTMENT OF THE INTERIOR \\ BRUCE BABBITT, Secretary
}

\author{
U.S. GEOLOGICAL SURVEY
}

Thomas J. Casadevall, Acting Director

The use of firm, trade, and brand names in this report is for identification purposes only and does not constitute endorsement by the U.S. Geological Survey.

For additional information write to:

District Chief

U.S. Geological Survey

Box 25046, Mail Stop 415

Denver Federal Center

Denver, CO 80225-0046
Copies of this report can be purchased from:

U.S. Geological Survey

Information Services

Box 25286

Federal Center

Denver, CO 80225 


\section{CONTENTS}

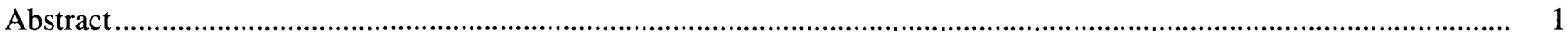

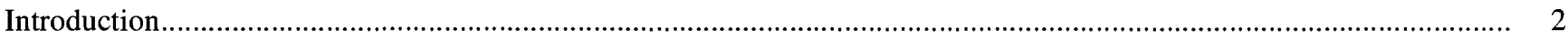

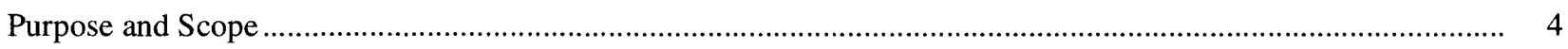

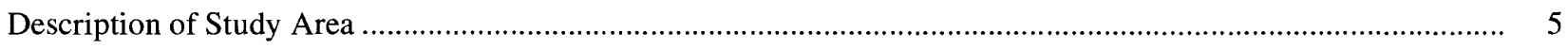

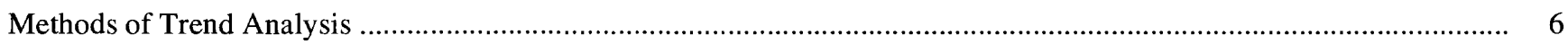

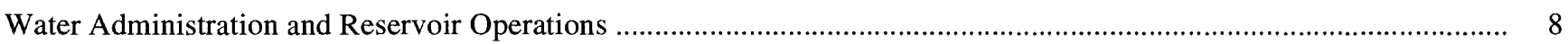

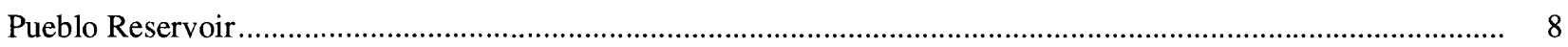

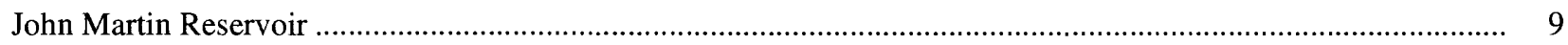

General Discussion of Streamflow and Specific Conductance in the Arkansas River.............................................. 10

Relations of Streamflow and Specific-Conductance Trends to Reservoir Operations in the Arkansas River ................... 11

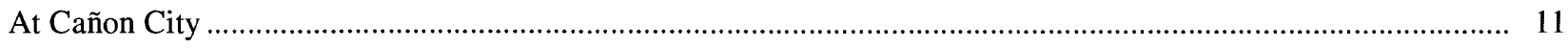

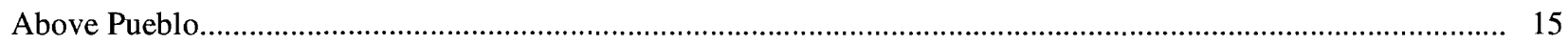

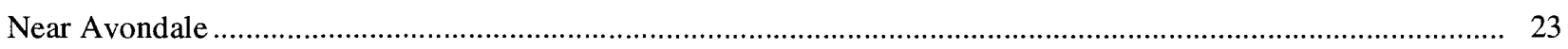

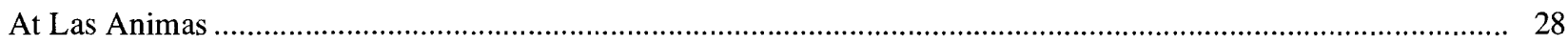

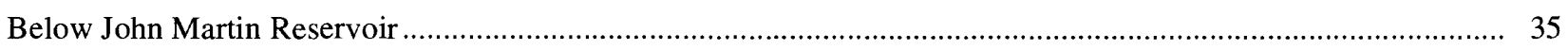

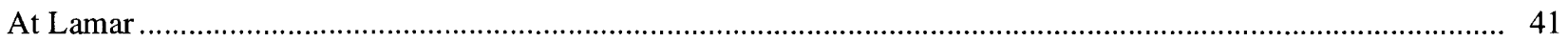

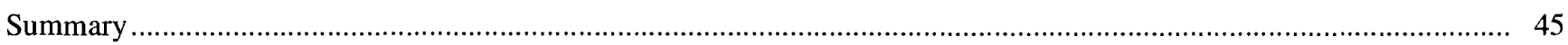

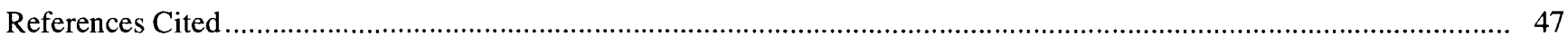

\section{FIGURES}

1. Map showing location of study area and streamflow-gaging stations ............................................................. 3

2-27. Graphs showing:

2. Example of a boxplot

3. Daily mean streamflow at selected Arkansas River gaging stations, 1982 _................................................. 10

4. Median specific conductance at selected sites on the Arkansas River, 1990-93............................................ 12

5. Daily mean streamflow at station 07096000 (Arkansas River at Cañon City), 1964-74 and 1975-94

6. Total annual volume of water imported into the Arkansas River from the Colorado River Basin, 1964-94.

7. Specific conductance at station 07096000 (Arkansas River at Cañon City), 1964-94

8. Monthly specific conductance at station 07096000 (Arkansas River at Cañon City), 1964-74 and 1975-94

9. Daily mean streamflow at station 07099400 (Arkansas River above Pueblo), 1966-74 and 1975-94

10. Specific conductance at station 07099400 (Arkansas River above Pueblo), 1966-94

11. Monthly specific conductance at station 07099400 (Arkansas River above Pueblo), 1966-74 and 1975-94

12. Duration frequency of specific conductance at station 07099400 (Arkansas River above Pueblo); Arkansas River at diversion for the Pueblo Board of Water Works; and Arkansas River at diversion for the St. Charles Mesa Water District, 1966-74 and 1975-94

13. Daily mean streamflow at station 07109500 (Arkansas River near Avondale), 1969-74 and 1975-94.

14. Specific conductance at station 07109500 (Arkansas River near Avondale), 1969-94

15. Monthly specific conductance at station 07109500 (Arkansas River near Avondale), 1969-74 and 1975-94 
16. Duration frequency of specific conductance at station 07109500 (Arkansas River near Avondale), 1969-74 and 1975-94

17. Daily mean streamflow at station 07124000 (Arkansas River at Las Animas), 1961-74 and 1975-94

18. Relation of cumulative annual streamflow at station 07109500 (Arkansas River near Avondale) to cumulative annual streamflow at four downstream sites, 1966-94 ............................... 32

19. Specific conductance at station 07124000 (Arkansas River at Las Animas), 1961-94 ............................... 33

20. Monthly specific conductance at station 07124000 (Arkansas River at Las Animas), 1961-74 and 1975-94

21. Median end-of-month contents of John Martin Reservoir, 1955-79 and 1980-94 ....................................... 36

22. Daily mean streamflow at station 07130500 (Arkansas River below John Martin Reservoir), 1955-79 and 1980-94

23. Specific conductance at station 07130500 (Arkansas River below John Martin Reservoir), 1955-94.

24. Monthly specific conductance at station 07130500 (Arkansas River below John Martin Reservoir), 1955-79 and 1980-94.

25. Daily mean streamflow at station 07133000 (Arkansas River at Lamar), 1964-79 and 1980-94.

26. Specific conductance at station 07133000 (Arkansas River at Lamar), 1964-94

27. Monthly specific conductance at station 07133000 (Arkansas River at Lamar), 1964-79 and 1980-94

\section{TABLES}

1. Main-stem stations for which streamflow and specific-conductance trends were analyzed

2. Step-trend results on the daily mean streamflow at station 07096000 (Arkansas River at Cañon City) between 1964-74 and 1975-94

3. Step-trend results on specific conductance at station 07096000 (Arkansas River at Cañon City) between 1964-74 and 1975-94

4. Step-trend results on the daily mean streamflow at station 07099400 (Arkansas River above Pueblo) between 1966-74 and 1975-94.

5. Step-trend results on specific conductance at station 07099400 (Arkansas River above Pueblo) between 1966-74 and 1975-94.

6. Step-trend results on the daily mean streamflow at station 07109500 (Arkansas River near Avondale) between 1969-74 and 1975-94

7. Step-trend results on specific conductance at station 07109500 (Arkansas River near Avondale) between 1969-74 and 1975-94.

8. Step-trend results on the daily mean streamflow at station 07124000 (Arkansas River at Las Animas) between 1961-74 and 1975-94

9. Step-trend results on specific conductance at station 07124000 (Arkansas River at Las Animas) between 1961-74 and 1975-94

10. Step-trend results on the daily mean streamflow at station 07130500 (Arkansas River below John Martin Reservoir) between 1955-79 and 1980-94.

11. Step-trend results on specific conductance at station 07130500 (Arkansas River below John Martin Reservoir) between 1955-79 and 1980-94

12. Step-trend results on the daily mean streamflow at station 07133000 (Arkansas River at Lamar) between 1964-79 and 1980-94

13. Step-trend results on specific conductance at station 07133000 (Arkansas River at Lamar) between 1964-79 and 1980-94 


\begin{tabular}{rcl} 
Multiply & By & To obtain \\
acre & 0.4047 & hectare \\
acre-foot (acre-ft) & 1,233 & cubic meter \\
acre-foot per year (acre-ft/yr) & 1,233 & cubic meter per year \\
cubic foot per second (ft $\left.{ }^{3} / \mathrm{s}\right)$ & 0.02832 & cubic meter per second \\
foot $(\mathrm{ft})$ & 0.3048 & meter \\
inch (in.) & 25.4 & millimeter \\
mile $\left.(\mathrm{mi})^{2}\right)$ & 1.609 & kilometer \\
square mile (mi $\left.{ }^{2}\right)$ & 2.59 & kilometer \\
ton per year (ton/yr) & 0.9072 & meter ton per year \\
& & \\
\hline
\end{tabular}

The following terms and abbreviations also are used in this report: microsiemens per centimeter at 25 degrees Celsius $(\mu \mathrm{S} / \mathrm{cm})$ milligram per liter $(\mathrm{mg} / \mathrm{L})$ 


\title{
Relations of Streamflow and Specific-Conductance Trends to Reservoir Operations in the Lower Arkansas River, Southeastern Colorado
}

\author{
By Michael E. Lewis and Daniel L. Brendle
}

\section{Abstract}

To provide for the better management of streamflow in the lower Arkansas River, two main-stem reservoirs were constructed. John Martin Reservoir, constructed near Las Animas in 1948, and Pueblo Reservoir, constructed near Pueblo in 1975, provide for flood control, irrigation, municipal water supply, and recreation. Both reservoirs have the potential to alter specific conductance in the Arkansas River because of streamflow management. A change in specific conductance could affect the intended use of the water as an agricultural or domestic water supply. Step-trend analysis of streamflow and specific-conductance data for the Arkansas River was used for determining if the operation of Pueblo Reservoir or John Martin Reservoir had affected streamflow or specific conductance in the lower Arkansas River. The nonparametric Mann-Whitney-Wilcoxon ranksum test was used for trend analysis.

Streamflow and specific-conductance data collected at five streamflow-gaging stations on the lower Arkansas River and at one station on the upper Arkansas River were analyzed for trends. The station in the upper basin was included in the analysis to differentiate between trends in the lower basin that were caused by differences in the quantity or quality of inflow from the upper basin or were caused by reservoir operations in the lower basin. Data from the station in the upper basin and from the three stations located between Pueblo Reservoir and John Martin Reservoir were analyzed for trends that may have occurred after 1974, which corresponds to the construction of Pueblo Reservoir. Data from the two stations located downstream from John Martin Reservoir were analyzed for trends that may have occurred after the implementation of a new reservoir operating plan in 1980.

At the station in the upper basin, streamflow increased significantly and specific conductance decreased significantly after 1974 during the low-flow months, January, February, and March. These trends apparently were caused by the increased importation of low-specificconductance water after 1974 from the Colorado River Basin into the Arkansas River. At the three stations located between Pueblo Reservoir and John Martin Reservoir, streamflow and specific conductance primarily were affected by Pueblo Reservoir operations. After 1974, at the two stations located 0.4 and 24 miles downstream from Pueblo Reservoir, streamflow generally increased during most months of the growing season and decreased during November through February. The streamflow trends at these two stations largely were attributed to the storage of water in Pueblo Reservoir during winter and to the release of that stored water during the growing season in order to meet downstream irrigation needs. At the station $0.4 \mathrm{mi}$ downstream from Pueblo Reservoir, specific conductance decreased during most months between September and 
April and increased during the high-flow months, May and June. This trend was caused by the mixing of seasonally low-specific-conductance water and seasonally high-specific-conductance water in Pueblo Reservoir, thus narrowing the annual range in specific conductance in the reservoir outflow. Few trends, except for increased specific conductance in June, August, and December, were detected in specific conductance at the station located 24 miles downstream from Pueblo Reservoir. The increase in specific conductance probably was caused by the combined effects of water storage and mixing in Pueblo Reservoir and the increased inflow of relatively high-specific-conductance water from Fountain Creek. At Las Animas, located 120 miles downstream from Pueblo Reservoir, streamflow increased significantly during all months after 1974. Specific conductance tended to decrease during all months, but the decreases generally were not statistically significant at the 95-percent confidence level.

At the two stations located downstream from John Martin Reservoir, specific conductance was affected by changes in John Martin Reservoir operations, increases in the reservoir inflow, and decreases in the specific conductance of the reservoir inflow. Specific conductance decreased during September through April and did not change substantially during May through August. These trends were very similar to trends observed immediately downstream from Pueblo Reservoir and were attributed largely to increased storage and increased mixing of seasonally lowand seasonally high-specific-conductance water in John Martin Reservoir. These factors tended to increase the minimum specific conductance and decrease the maximum specific conductance in the reservoir outflow.

\section{INTRODUCTION}

The lower Arkansas River in southeastern Colorado extends about 200 mi downstream from Pueblo Reservoir to the Colorado-Kansas State line (fig. 1). The Arkansas River is the primary municipal water supply for most of the 165,580 people who live in the five counties that compose the lower Arkansas River Valley and the primary agricultural irrigation supply for about 300,000 acres of irrigated land in the lower basin. Because of this dependence on the Arkansas River as a municipal and an agricultural water supply, the quality of water in the Arkansas River is very important.

The quality of water in the Arkansas River is markedly different throughout the study area. Specific conductance, which is directly related to dissolvedsolids concentration, increases downstream from a median of about $500 \mu \mathrm{S} / \mathrm{cm}$ near Pueblo to about $3,900 \mu \mathrm{S} / \mathrm{cm}$ at Lamar (fig. 1); this range in specific conductance corresponds to a range in dissolvedsolids concentration of about 340 to $3,600 \mathrm{mg} / \mathrm{L}$ (Cain, 1987). The downstream increase in specific conductance and, hence, in dissolved solids, largely is due to the consumptive use of surface water and ground water for agricultural irrigation (Miles, 1977). High specific conductance is indicative of high dissolved-solids concentration; dissolved solids can affect the suitability of water for domestic, industrial, and agricultural uses. The secondary maximum contaminant level (SMCL) for dissolved solids in drinking water is $500 \mathrm{mg} / \mathrm{L}$ (U.S. Environmental Protection Agency, 1986). In the lower Arkansas River, $500 \mathrm{mg} / \mathrm{L}$ of dissolved solids is equivalent to a specific conductance of about 700 to $800 \mu \mathrm{S} / \mathrm{cm}$ (Cain, 1987). At higher levels, drinking water may have an unpleasant taste or odor or even cause gastrointestinal distress. Additionally, high dissolvedsolids concentrations can cause increased deterioration of plumbing fixtures and appliances. Relatively expensive, advanced water-treatment processes, such as reverse osmosis, are needed to remove excessive dissolved solids from water.

Agriculture also can be adversely affected by high-specific-conductance water. Depending on the crop, agricultural losses might occur when dissolved-solids concentrations reach 700 to $850 \mathrm{mg} / \mathrm{L}$ (U.S. Department of the Interior, 1994), which is equivalent to a specific conductance of about 950 to $1,200 \mu \mathrm{S} / \mathrm{cm}$ in the Arkansas River (Cain, 1987). With increasing specific conductance, special agricultural management practices may be needed and crops having a substantial salinity tolerance may need to be grown. Generally, crops with a higher salinity tolerance have a lower market value than salt-sensitive crops (Miles, 1977). 

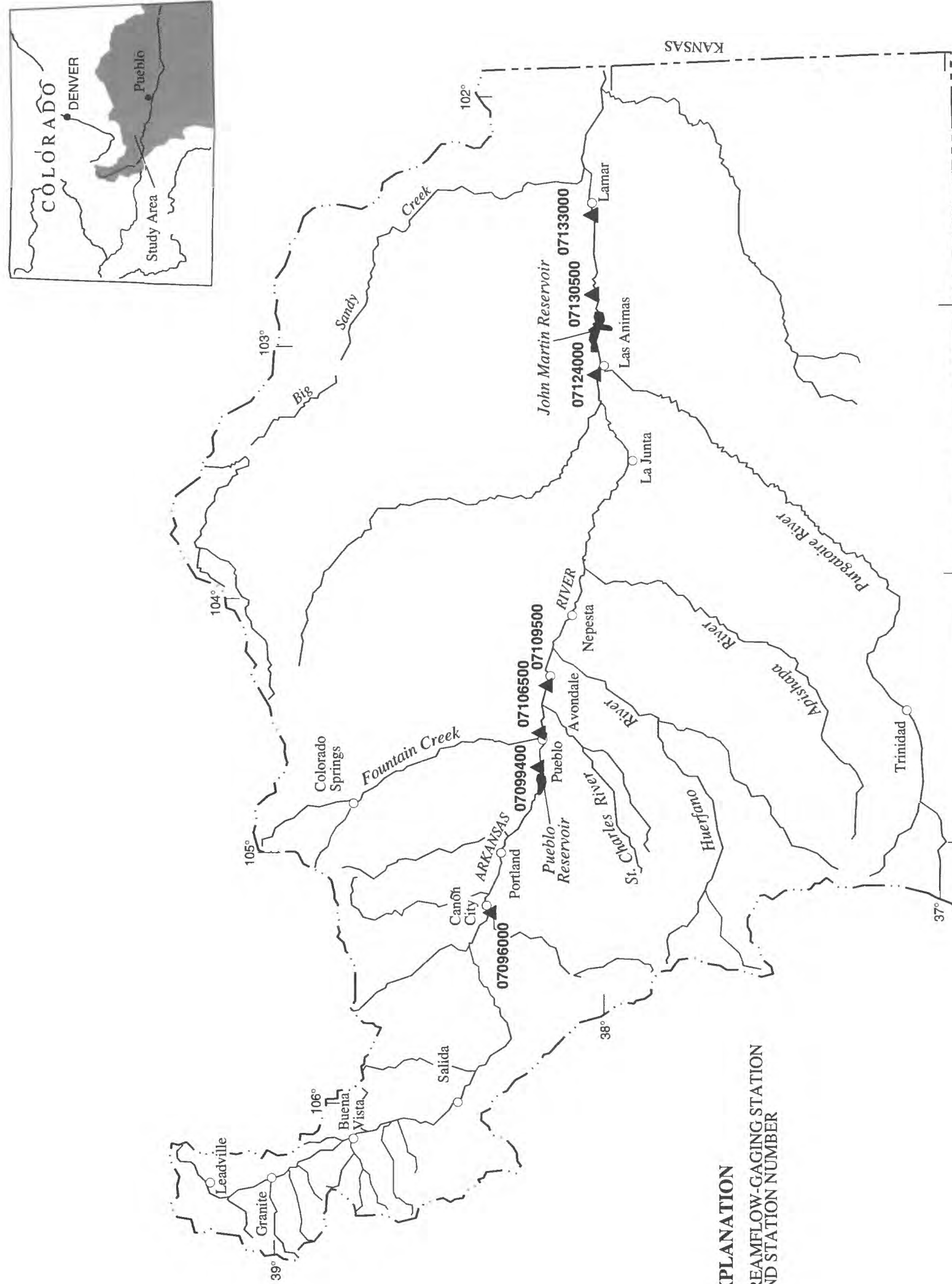
Streamflow in the lower Arkansas River is regulated by the storage and release operations of two main-stem reservoirs, Pueblo Reservoir and John Martin Reservoir. Because of streamflow manipulation, both reservoirs can cause increases or decreases in the dilution potential in the river and, thus, can affect specific conductance. Although the specific-conductance conditions and the relations between specific conductance and streamflow in the Arkansas River have been well documented (Miles, 1977; Cain, 1985, 1987), the effects of main-stem reservoir operations on specific conductance have not been systematically studied and reported.

Beginning in 1988, the U.S. Geological Survey initiated a basinwide study of water quality in the Arkansas River and of the effects of certain water-supply operations on water quality, including the relations of streamflow and specificconductance trends to reservoir operations in the lower Arkansas River. The study was conducted in cooperation with the Colorado Springs Utilities; Pueblo Board of Water Works; Southeastern Colorado Water Conservancy District; Pueblo County, Department of Planning and Development; city of Aurora, Department of Utilities; St. Charles Mesa Water District; Upper Arkansas Area Council of Governments; Upper Arkansas Water Conservancy District; city of Pueblo, Department of Utilities; Pueblo West Metropolitan District; Fremont Sanitation District; and cities of Rocky Ford, Las Animas, and Lamar.

\section{Purpose and Scope}

This report presents: (1) Step-trend analysis results for streamflow and specific conductance at three main-stem Arkansas River streamflowgaging stations located between Pueblo Reservoir and John Martin Reservoir and at two main-stem stations located between John Martin Reservoir and the Colorado-Kansas State line, and (2) a determination of whether significant streamflow and specificconductance trends are related to the operations of the reservoirs. Daily mean streamflow data and discrete specific-conductance data were used in the trend analyses. The five main-stem stations were selected for trend analysis because of the availability of long-term streamflow and specific-conductance data.
Additionally, streamflow and specific-conductance trends were evaluated at station 07096000 (Arkansas River at Cañon City), which is in the upper basin about 28 mi upstream from Pueblo Reservoir (fig. 1). This station was included in the analysis to help differentiate whether trends in the lower basin were caused by differences in the quantity or quality of inflow from the upper basin or were caused by reservoir operations in the lower basin. Although specific-conductance trends were the main focus of this study, streamflow trends also were analyzed because streamflow and specific conductance generally are correlated; therefore, changes or trends in specific conductance often can be explained in terms of the associated change or trend in streamflow.

All streamflow and specific-conductance data used for trend analysis in this study are available from the U.S. Geological Survey National Water Data Storage and Retrieval System (WATSTORE). Additionally, all streamflow and specific-conductance data used for trend analysis in this study were published in annual data reports (U.S. Geological Survey, 1959, 1960, 1961, 1962-65, 1963a, 1963b, 1964, 1965a, 1965b, 1966-75a, 1966-75b, 1976-95).

At individual stations, the record length for specific-conductance data generally was shorter than the record for streamflow. Therefore, the streamflowrecord length for individual stations was shortened to match the specific-conductance record for that station. This matching of record lengths facilitated the direct comparison of streamflow and specificconductance trends at individual stations. Because record lengths differed between stations (table 1), trend results were not quantitatively compared between stations. At most stations, the effects of tributary streamflow and specific conductance were not considered in the trend analysis because of a lack of tributary streamflow and specific-conductance data. The exception was station 07106500 (Fountain Creek at Pueblo), which is tributary to the Arkansas River near Pueblo (fig. 1) and for which there exists longterm streamflow and specific-conductance data.

Streamflow and specific-conductance data from the three stations located between Pueblo Reservoir and John Martin Reservoir were evaluated for trends that might have occurred after the construction of Pueblo Reservoir in 1975. Data from the two stations located downstream from John Martin Reservoir were evaluated for trends that might have occurred 
following the implementation of the 1980 John Martin Reservoir operating plan (Arkansas River Compact Administration, 1980). Similarly, data collected in the upper basin at station 07096000 were evaluated for trends that might have occurred after 1975 because this station was used in the study to evaluate trends in the quantity and quality of inflow into Pueblo Reservoir and the lower basin.

Table 1. Main-stem stations for which streamflow and specific-conductance trends were analyzed

\begin{tabular}{lcc}
\hline \multicolumn{1}{c}{$\begin{array}{c}\text { Station } \\
\text { name }\end{array}$} & $\begin{array}{c}\text { U.S. Geological } \\
\text { Survey station } \\
\text { number }\end{array}$ & $\begin{array}{c}\text { Period of } \\
\text { trend } \\
\text { analysis }\end{array}$ \\
\hline $\begin{array}{l}\text { Arkansas River at } \\
\text { Cañon City }\end{array}$ & 07096000 & $1964-94$ \\
$\begin{array}{l}\text { Arkansas River above } \\
\text { Pueblo }\end{array}$ & 07099400 & $1966-94$ \\
$\begin{array}{l}\text { Arkansas River near } \\
\text { Avondale }\end{array}$ & 07109500 & $1969-94$ \\
$\begin{array}{l}\text { Arkansas River at } \\
\text { Las Animas }\end{array}$ & 07124000 & $1961-94$ \\
$\begin{array}{l}\text { Arkansas River below } \\
\text { John Martin Reservoir }\end{array}$ & 07130500 & $1955-94$ \\
$\begin{array}{l}\text { Arkansas River at } \\
\text { Lamar }\end{array}$ & 07133000 & $1964-94$ \\
\hline
\end{tabular}

\section{Description of Study Area}

The study area includes the Arkansas River Basin in southeastern Colorado from the foothills of the Rocky Mountains near Cañon City to Lamar, a distance of about $200 \mathrm{mi}$ (fig. 1). The Arkansas River headwaters are located to the northwest of the study area near Leadville. The river flows south and east through mountainous terrain before emerging from the mountains near Cañon City, at an altitude of about $5,350 \mathrm{ft}$. At Pueblo, the river is impounded to form Pueblo Reservoir. Downstream from Pueblo, the river flows eastward across flat terraces and almost level flood plains, an area commonly referred to as the lower Arkansas River Valley. Immediately downstream from Las Animas, the river is impounded by John Martin Reservoir. About 58 mi downstream from John Martin Reservoir, the river flows into Kansas. The Arkansas River drains an area of about $25,400 \mathrm{mi}^{2}$ in Colorado, including $4,669 \mathrm{mi}^{2}$ upstream from Pueblo Reservoir.
The semiarid climate of the study area is characterized by low to moderate precipitation, substantial evaporation, low humidity, moderate to intense winds, and a large daily range in temperature. Mean annual precipitation ranges from 12 in. at Pueblo to 15 in. at Lamar. About 75 to 80 percent of the annual precipitation falls as rain during the growing season. Throughout the area, potential evapotranspiration greatly exceeds precipitation.

Land use along the Arkansas River in the lower Arkansas River Basin is predominantly agricultural. Major crops are alfalfa, corn, wheat, and sorghum; about 300,000 acres are irrigated. Most of the irrigated acreage is located in the alluvial valley of the Arkansas River, along the major tributaries, and near off-channel reservoirs. Crop types grown in the valley generally vary downstream by their salinity tolerance. Vegetables and other salt-sensitive crops are grown on proportionally more acreage upstream from La Junta where salinity is lower; alfalfa, which is relatively salt tolerant, is grown on proportionally more acreage downstream from La Junta where salinity is much higher (Miles, 1977).

The Arkansas River is a partially penetrating stream that is incised into the alluvial deposits that form the valley-fill aquifer of the Arkansas River Valley. The valley-fill aquifer, which extends from Pueblo to the downstream end of the study area, is an unconfined system that directly underlies and is in hydraulic connection with the Arkansas River. The aquifer width varies from 1 to $14 \mathrm{mi}$ and averages 3 to $5 \mathrm{mi}$. The thickness of the alluvium varies from 0 to about $250 \mathrm{ft}$. The alluvium consists of fairly well-sorted sand and gravel with minor amounts of clay. Depth to water varies from $0 \mathrm{ft}$ in wetlands in the study area to about $40 \mathrm{ft}$ in eastern Colorado, and the saturated thickness varies from less than $10 \mathrm{ft}$ to about $210 \mathrm{ft}$. Ground-water flow in the alluvial aquifer generally is from west to east (Hurr and Moore, 1972; Taylor and Luckey, 1974; Nelson and others, 1989a, b, c).

Snowmelt from the mountainous upper basin is the primary source of streamflow in the Arkansas River. Snowmelt runoff usually begins in late April or early May and peaks in June. In addition to native snowmelt runoff, streamflow in the Arkansas River is supplemented by the transmountain diversion of water from the Colorado River Basin. Transmountain water is diverted into the Arkansas River Basin at locations that are more than $150 \mathrm{mi}$ upstream from Pueblo 
Reservoir. The transmountain water is imported during the summer and can be stored in several offchannel reservoirs in the upper basin or in Pueblo Reservoir. The imported water may be released from storage to meet downstream municipal or irrigation water-supply demands. Rainfall runoff, ground-water inflow, and irrigation-return flow also contribute to flow in the Arkansas River. A substantial amount of the water in the Arkansas River is diverted and consumptively used for irrigation in the study area. During 1955-94, the median annual streamflow in the Arkansas River decreased downstream by about 88 percent from Pueblo (448,000 acre-ft/yr) to Lamar $(53,700 \mathrm{acre}-\mathrm{ft} / \mathrm{yr})$, largely because of irrigation diversions. Irrigation-return flow from tributary streams, drainage ditches, and the alluvial aquifer supplements flow in the Arkansas River, and much of the streamflow in the river downstream from La Junta consists of irrigation-return flow during parts of many years (Cain, 1987).

\section{METHODS OF TREND ANALYSIS}

Trend analysis can be used to determine if streamflow or water quality has changed over time. In this study, step-trend analysis was used to determine streamflow and specific-conductance trends in the Arkansas River. In a step-trend analysis, data collected before a specific time are assumed to be from a distinctly different data population than data collected after that time. The difference between the data populations is assumed to be one of location (for example, mean or median), but not necessarily of scale (for example, variance or interquartile range). The step-trend analysis is much more specific than other trend analyses (for example, monotonic trend analysis) because step-trend analysis requires that a particular fact, the time of the change, is known before any examination of the data. It is imperative that the decision to use step-trend analysis not be based on prior examination of the data because prior examination would bias the significance level of the test. Significance levels, as represented by the individual $p$ values of each test, were for the two-sided trend test because no prior determination of the direction of trends was made. For this study, a significant test was defined at a 95-percent confidence level $(\mathrm{p} \leq 0.05)$. The steptrend analysis is particularly well suited to this study because the purpose of the study was to determine if streamflow or specific conductance at a particular location on the Arkansas River changed after the construction of Pueblo Reservoir (1975) or after the implementation of the John Martin Reservoir 1980 operating plan.

Step-trend analysis was done using the nonparametric Mann-Whitney-Wilcoxon rank-sum test (Bradley, 1968). This nonparametric procedure was selected because the data (streamflow and specific conductance) generally were not normally distributed, based on graphical data analysis. Nonparametric procedures have more power (or efficiency) than parametric procedures in cases where there is a substantial departure from normality (Helsel and Hirsch, 1988).

In addition to doing trend analysis on daily mean streamflow data and specific-conductance data that were grouped by month, specific-conductance data were analyzed for trends with data grouped by season. One problem with using monthly specificconductance data is that the sample sizes are smaller compared to data sets consisting of several months of data. The $\mathrm{p}$ value for hypothesis testing is affected by sample size. For a given trend magnitude and variance, $p$ values tend to increase as the sample size decreases (Helsel and Hirsch, 1992); therefore, it becomes more difficult to reject the null hypothesis of no trend as the sample size decreases. Grouping specific-conductance data by season increased the sample sizes of the data sets being analyzed. The seasonal grouping was based on the timing of waterstorage and release operations for Pueblo Reservoir and John Martin Reservoir. For the streamflowgaging stations located between Pueblo Reservoir and John Martin Reservoir, data were grouped by growing season (March 16-November 14) or winterstorage season (November 15-March 15). For the streamflow-gaging stations located downstream from John Martin Reservoir, data were grouped by growing season (April 1-October 31) or winter-storage season (November 1-March 31). A thorough description of the factors affecting these seasonal groupings is provided in the following "Water Administration and Reservoir Operations" section.

Qualitative comparisons of streamflow and specific-conductance data were made using boxplots. Boxplots are useful because variability between data sets and unusually large or small values in a data set can easily be seen. For this report, boxplots were constructed to compare monthly differences in daily mean streamflow and specific-conductance data at particular main-stem sites before and after implementation of reservoir operations. Boxplots contain the 
following information (fig. 2). The horizontal line inside the box represents the median value ( 50 percent of the data are greater than this value and 50 percent of the data are less than this value). The lower line of the box is the 25 th or lower quartile ( 25 percent of the data are less than this value). The upper line of the box is the 75th percentile or upper quartile (75 percent of the data are less than this value). The interquartile range (IQR) contains the values between the 25 th and 75 th percentiles and is the difference between the 25 th and 75 th percentiles. The bottom of the vertical line on the boxplot is the smallest value within 1.5 times the IQR of the box. The top of the vertical line is the largest value within 1.5 times the IQR of the box. Outside values, shown as *, are greater than 1.5 times and less than 3 times the IQR from the box. The far outside values, shown as $\mathrm{O}$, are greater than three times the IQR from the box. The number of data values used to construct each boxplot is presented at the top of the boxplot.

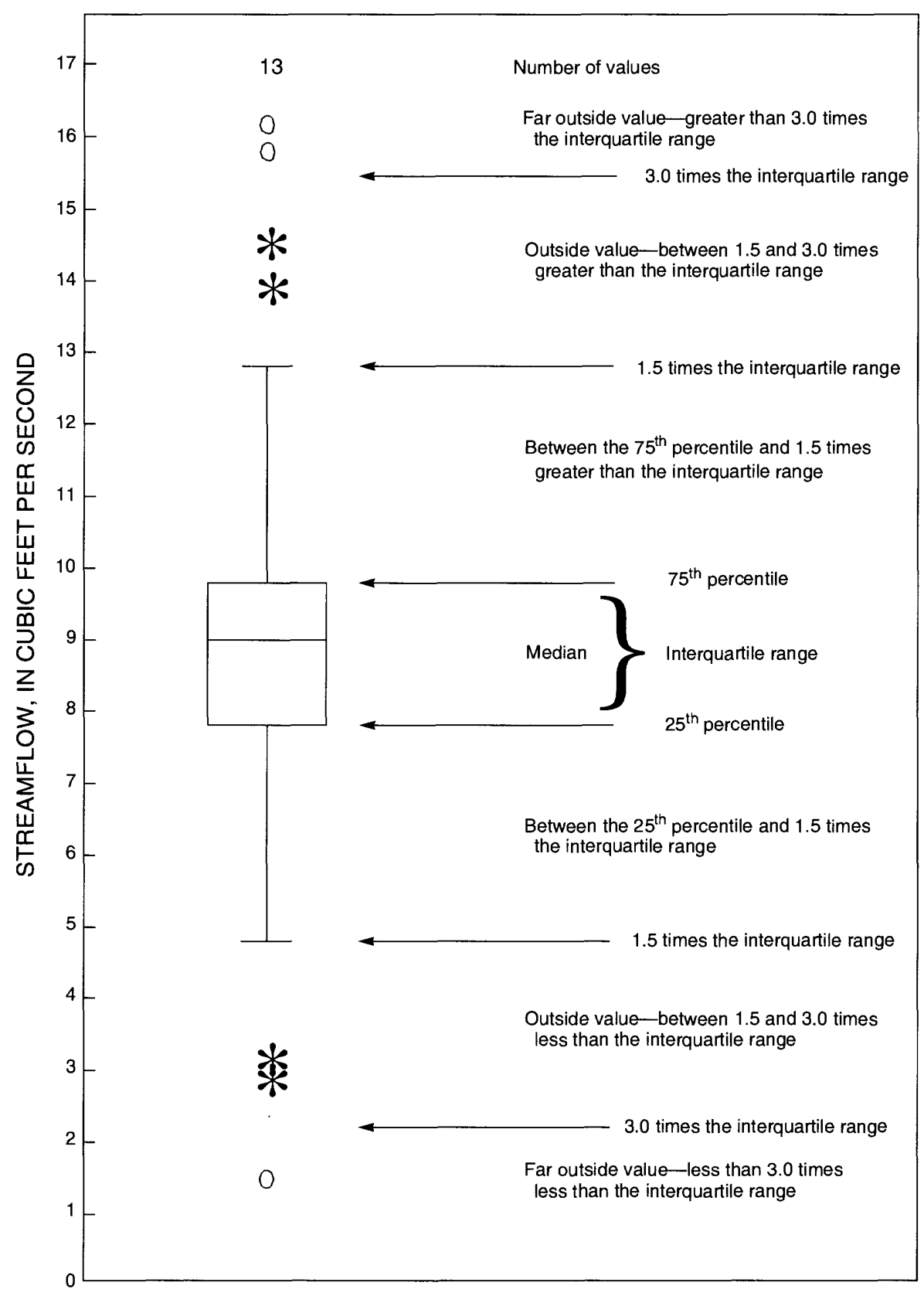

Figure 2. Example of a boxplot. 
Statistical analyses were made of daily mean streamflow values. The daily mean streamflow is the mean streamflow for a given date and site. The median daily mean streamflow for a given month is the median value of all daily mean streamflows for that month during a specified period of time.

\section{WATER ADMINISTRATION AND RESERVOIR OPERATIONS}

In Colorado, water law is based on the doctrine of prior appropriation. The prior appropriation doctrine holds that the water in a State is the property of the public, which has a vested right to the use of this water. Specifically, the doctrine states that the first in time to use the water is first in right to receive that water in subsequent years. Prioritized direct-flow water rights for the Arkansas River were established as long ago as 1859. As irrigated agriculture spread throughout the basin, the list of prioritized water rights grew rapidly, and the Arkansas River and its tributaries were fully appropriated for normal or average years by the mid-1880's (Abbott, I985). In most areas, water rights with priorities dated after 1887 are little more than flood rights, which allow diversion of water only in periods of higher than average streamflow (Abbott, 1985). Flood rights do not provide a dependable supply of water because these flows generally occur at times inconvenient to farming operations or at rates in excess of canal capacities. Water-storage rights were developed and reservoirs were constructed to take advantage of the flow not available to direct diversions, which includes streamflow in excess of direct-flow water rights (flood rights) and streamflow during the nonirrigation season (winter water) from November through March. During I880 through 19I0, storage rights were established that allowed for the yearly diversion and storage of almost 500,000 acre- $\mathrm{ft}$ of Arkansas River water in off-channel reservoirs. Additionally, two large main-stem reservoirs were built in the lower Arkansas River Valley to manage Arkansas River streamflow. In I948, the U.S. Army Corps of Engineers completed construction of John Martin Reservoir, a main-stem reservoir east of Las Animas (fig. 1). In 1975, the Bureau of Reclamation completed construction of Pueblo Reservoir, a main-stem reservoir west of Pueblo (fig. 1).

\section{Pueblo Reservoir}

Pueblo Reservoir is used for the storage and regulation of water that is imported into the Arkansas River Basin from the Colorado River Basin as part of the Fryingpan-Arkansas Project (hereafter referred to as the Project). The Project is a multipurpose water development constructed by the Bureau of Reclamation. The main purpose of the Project is to divert unappropriated water from the western slope of Colorado for use on the more populated, water-limited eastern slope. The Project began importing water in I972. From I972 through 1994, the Project imported an annual median volume of about 47,300 acre-ft into the Arkansas River Basin (U.S. Department of the Interior, 1996). During summer, the Project diverts water from the western slope to the eastern slope, where the water is held in storage until municipal or irrigation water-supply demands need to be satisfied. Imported water may be stored in the upper basin or in Pueblo Reservoir, the farthest downstream facility of the Project. Imported water generally is stored in the upper basin as long as possible to minimize evaporative losses, which are lower in the upper basin than in Pueblo Reservoir. During winter, water stored in the upper basin may be released to the river for downstream storage in Pueblo Reservoir in order to create upper basin storage space for the importation of western slope water during the upcoming snowmelt runoff.

Storage began in Pueblo Reservoir in 1974, and the dam was completed in I975. The reservoir had an initial storage capacity of 357,678 acre-ft (Lewis and Edelmann, 1994). Since water was first impounded in Pueblo Reservoir, reservoir storage has fluctuated because of variations in the inflow and in the demand for stored water. Most of the storage space in Pueblo Reservoir is reserved for Project water, although storage of some non-Project water is granted under a limited number of storage contracts. Most of the annual inflow to the reservoir usually occurs during May through July. Reservoir storage generally decreases substantially by the end of the growing season because of decreased inflow and large downstream demands for irrigation water. 
The operation of Pueblo Reservoir, in particular the Winter Water Storage Program (WWSP), has a notable effect on the historic streamflow regime of the lower Arkansas River. In winter (November-March), prior to the implementation of the WWSP in 1975, irrigators in the lower Arkansas River Valley generally diverted appropriated Arkansas River water onto fallow fields to increase soil moisture for later use by crops during the growing season. Alternatively, this water could have been stored during the winter and then released to the river for the downstream irrigators to use during times when streamflow was insufficient to meet irrigation needs. However, under Colorado water law, storage of water that is diverted with directflow water rights is not permitted. Therefore, the WWSP was created to allow several irrigation canal companies downstream from Pueblo Reservoir to store their direct-flow water in Pueblo Reservoir, John Martin Reservoir, and in several private offchannel reservoirs during the winter and to use this water during the crop-growing season. Under the WWSP, winter water storage is allowed from November 15 to March 15. Generally, WWSP water is released from storage at times when streamflow is not large enough to meet irrigation demands. This situation usually occurs in early spring or late summer and autumn. Winter water was stored every year from 1975 to 1994 , except during the 1977-78 winterstorage season. During 1975-94, the median annual volume of water that was stored in Pueblo Reservoir as part of the WWSP was about 42,200 acre-ft (Colorado Division of Water Resources, written commun., 1995).

\section{John Martin Reservoir}

John Martin Reservoir is a 608,200-acre-ft main-stem reservoir located $58 \mathrm{mi}$ upstream from the Colorado-Kansas State line (fig. 1). The reservoir is used for flood control, irrigation-water storage, and recreation. Storage of irrigation water in John Martin Reservoir is by agreement between the States of Colorado and Kansas, under the terms of the Arkansas River Compact. The Arkansas River Compact is an agreement between Colorado and Kansas, signed in 1948, which ensures both States will receive their percentage share of Arkansas River flows. The Compact agreement dictated a winter- and a summer- storage period. During the winter-storage period from November 1 to March 31, all inflow to the reservoir was required to be stored, except that as much as $100 \mathrm{ft}^{3} / \mathrm{s}$ of water could be requested by Colorado water users downstream from the dam (Abbott, 1985). During the remainder of the year, river flow was stored, although Colorado could demand the release of as much as $500 \mathrm{ft}^{3} / \mathrm{s}$ of the water entering the reservoir and Kansas could demand releases of that part of the inflow between 500 and $750 \mathrm{ft}^{3} / \mathrm{s}$. Provisions were made for the rate of release of stored water, without reference to the volume of stored water assigned to each State. To ensure that each State received its share of stored water, release demands had to be made concurrently. Although the Arkansas River Compact was developed to ensure that Colorado and Kansas irrigators received their legal shares of Arkansas River water, the plan had several problems and generally was unsatisfactory to both States (Abbott, 1985). Historically, following the winterstorage period, reservoir storage was usually drawn down to empty or almost empty very early in the irrigation season, often by the middle of April. Because of the unsatisfactory nature of this operation, a resolution was adopted by the Arkansas River Compact Administration in 1980. This resolution commonly is referred to as the 1980 operating plan (Arkansas River Compact Administration, 1980). Under the new plan, any water not immediately called for and released to downstream irrigators is stored in separate storage accounts for the States of Colorado and Kansas. Either State can call for the release of its stored water independently of the other. Two other recent changes have been made in the operation of John Martin Reservoir that affect reservoir storage and streamflow downstream from John Martin Reservoir. A 10,000-acre-ft permanent recreation pool was established in 1976, and three irrigation canal companies have been allowed to store their approved WWSP water in John Martin Reservoir. Thirty-five percent of the winter water that the three canal companies store in John Martin Reservoir is shifted to Arkansas River Compact use and is subject to downstream release. These two changes, in conjunction with the 1980 operating plan, have substantially increased the long-term storage of water in John Martin Reservoir and have altered the flow regime in the Arkansas River downstream from the reservoir. 


\section{GENERAL DISCUSSION OF STREAMFLOW AND SPECIFIC CONDUCTANCE IN THE ARKANSAS RIVER}

Streamflow in the Arkansas River varies spatially and temporally because of the regular timing of snowmelt runoff in the upper basin, the irregular timing of rainfall runoff in the lower basin, the large magnitude of irrigation diversions, and the operations of

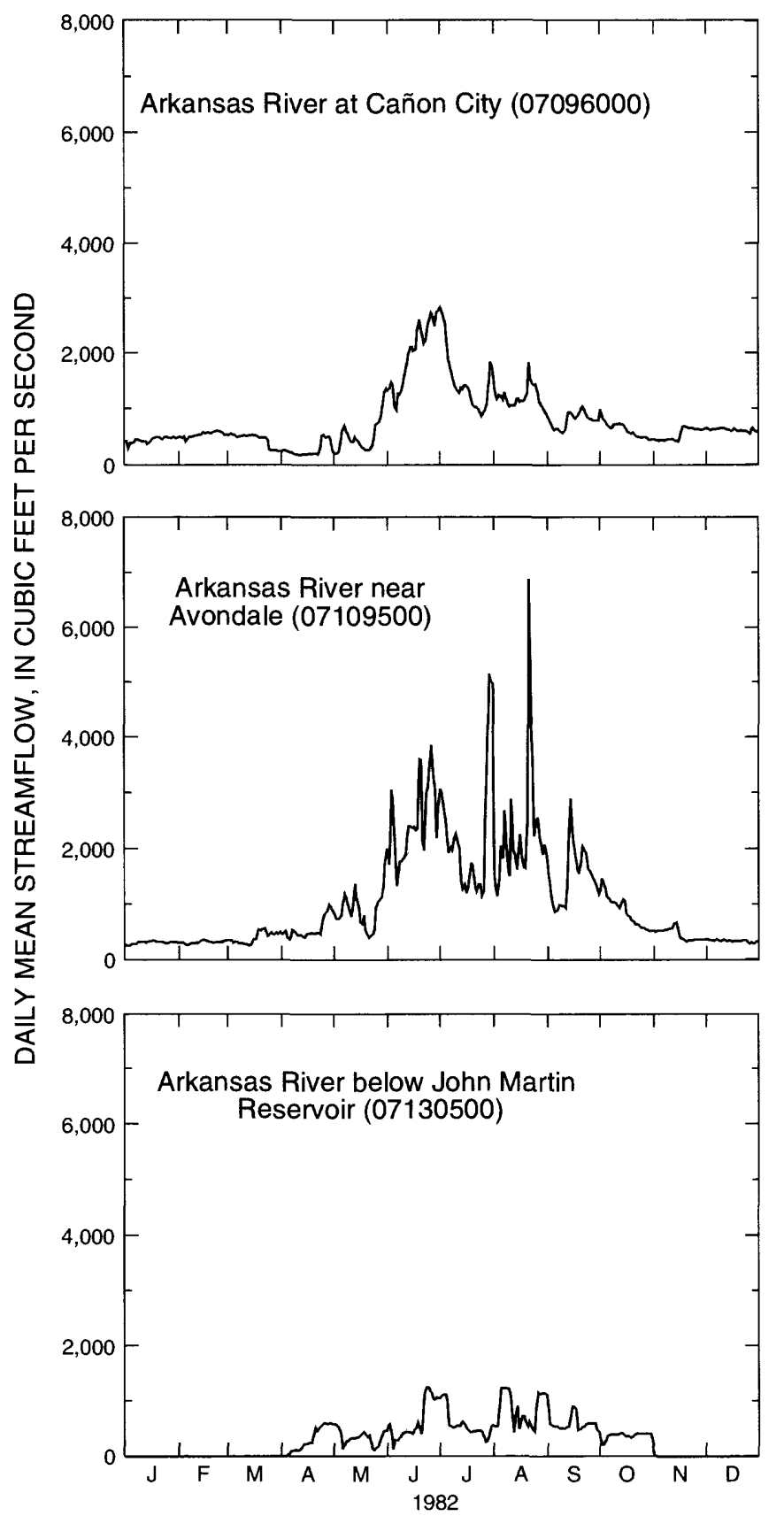

main-stem reservoirs. The general spatial and temporal patterns of streamflow in the Arkansas River are illustrated in the hydrographs for six main-stem Arkansas River stations for an average runoff year (1982) (fig. 3).

At station 07096000 (Arkansas River at Cañon City), which represents inflow from the upper basin to Pueblo Reservoir, the predominant effects on streamflow are due to snowmelt runoff and the release of stored water from off-channel reservoirs. Streamflow generally increases with snowmelt runoff in April or
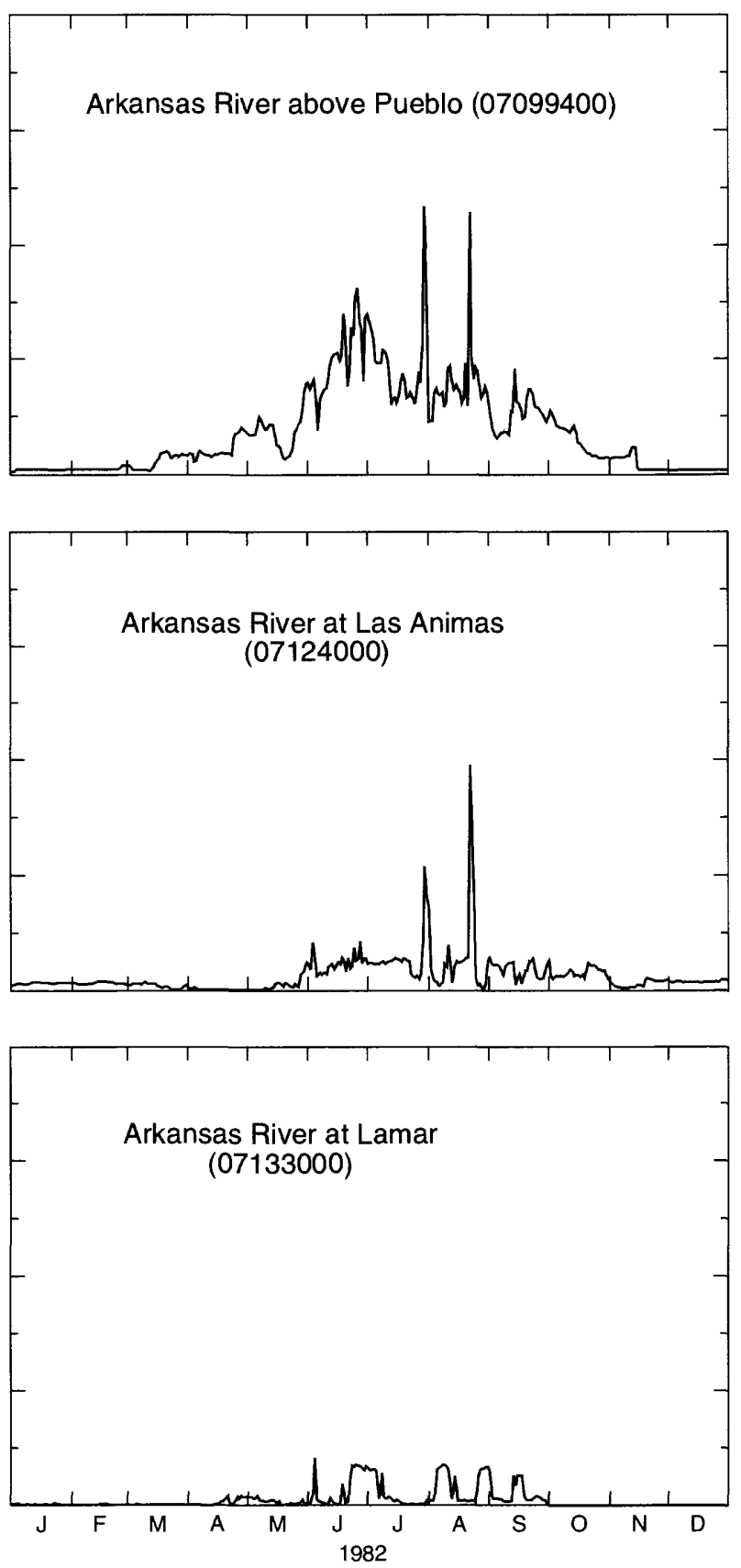

Figure 3. Daily mean streamflow at selected Arkansas River gaging stations, 1982. 
May and peaks in the middle or latter part of June. The recession of snowmelt runoff usually is supplemented by off-channel reservoir releases in the upper basin in July and August. Natural base flow and reservoir releases maintain streamflow during the low-flow period from October through March. At station 07099400 (Arkansas River above Pueblo), located 0.4 mi downstream from Pueblo Dam, streamflow is regulated by the operation of Pueblo Reservoir. The hydrograph for station 07099400 is similar to the hydrograph for station 07096000 , except that streamflow is considerably smaller at station 07099400 during November through March. At station 07109500 (Arkansas River near Avondale), located about $24 \mathrm{mi}$ downstream from Pueblo Reservoir, streamflow is affected by Pueblo Reservoir operations and by substantial tributary inflow from Fountain Creek and the St. Charles River. The shape of the hydrograph for station 07109500 is similar to the hydrograph for station 07099400 , except that tributary inflow from occasional rainfall runoff produces distinctly larger peaks, and the streamflow is substantially larger at station 07109500 during winter, owing to tributary inflow from Fountain Creek. At station 07124000 (Arkansas River at Las Animas), which is located 110 mi downstream from Pueblo Reservoir, the magnitude of streamflow is substantially smaller than at the upstream stations. The decrease in streamflow is attributable to irrigation diversions. As previously discussed in the "Description of Study Area" section, much of the streamflow in the river downstream from La Junta (fig. 1) consists of irrigation-return flow during parts of most years. Downstream from John Martin Reservoir at stations 07130500 (Arkansas River below John Martin Reservoir) and 07133000 (Arkansas River at Lamar), the annual hydrographs are regulated by the storage and release operations in John Martin Reservoir. The reservoir gates typically are closed during November through March, and all inflow is stored; winter streamflow at stations 07130500 and 07133000 is maintained by ground-water discharge. Requests for reservoir releases of stored water by downstream irrigators usually begin in the first 2 weeks of April and continue episodically through October. Rainfall runoff that is generated upstream from the reservoir is attenuated by storage in the reservoir. Streamflow between John Martin Reservoir and Lamar is substantially decreased by irrigation diversions.

Specific conductance in the Arkansas River markedly increases downstream from Pueblo (fig. 4). The downstream increase in specific conductance is a function of the evaporative concentration of dissolved solids. In 1990-93, during a period of intensive data collection, the median specific conductance increased downstream from $276 \mu \mathrm{S} / \mathrm{cm}$ at Cañon City to $3,855 \mu \mathrm{S} / \mathrm{cm}$ at Lamar (fig. 4). Miles (1977) reported that the dissolution of soluble sedimentary materials between Cañon City and Pueblo Reservoir increases specific conductance in that reach. From Pueblo to Lamar, specific conductance primarily increases because of the consumptive use of irrigation water and the concomitant increase in the concentration of dissolved solids. The rate of increase in specific conductance is larger downstream from Catlin Dam (fig. 4) because irrigation-return flow composes a larger percentage of streamflow in this reach than it does upstream from Catlin Dam (Cain, 1987).

\section{RELATIONS OF STREAMFLOW AND SPECIFIC-CONDUCTANCE TRENDS TO RESERVOIR OPERATIONS IN THE ARKANSAS RIVER}

\section{At Cañon City}

Station 07096000 (Arkansas River at Cañon City) is located in the upper Arkansas River Basin about 28 mi upstream from Pueblo Reservoir (fig. 1). Streamflow and specific-conductance trends were analyzed at this site to determine if the quantity and quality of water flowing from the upper basin into the lower basin were different during the period before the completion of Pueblo Reservoir (pre-1975) compared to the period after the completion of Pueblo Reservoir (post-1974). Streamflow and specific-conductance data were available for 1964-94. Streamflow and specific-conductance data from 1964 through 1974 were compared to data from 1975 through 1994.

The median annual streamflow at station 07096000 increased from about 520,800 acre-ft/yr in 1964-74 to about 538,600 acre-ft/yr in 1975-94; however, this difference in streamflow was not statistically significant $(\mathrm{p}=0.92)$. Although there was no significant change in the median annual streamflow, the daily mean streamflow changed substantially in several months of the two periods (fig. 5). Daily mean streamflow increased significantly $(\mathrm{p} \leq 0.05)$ between 1964-74 and 1975-94 in January, February, March, April, June, October, November, and December (table 2). Most of the increases occurred during low 


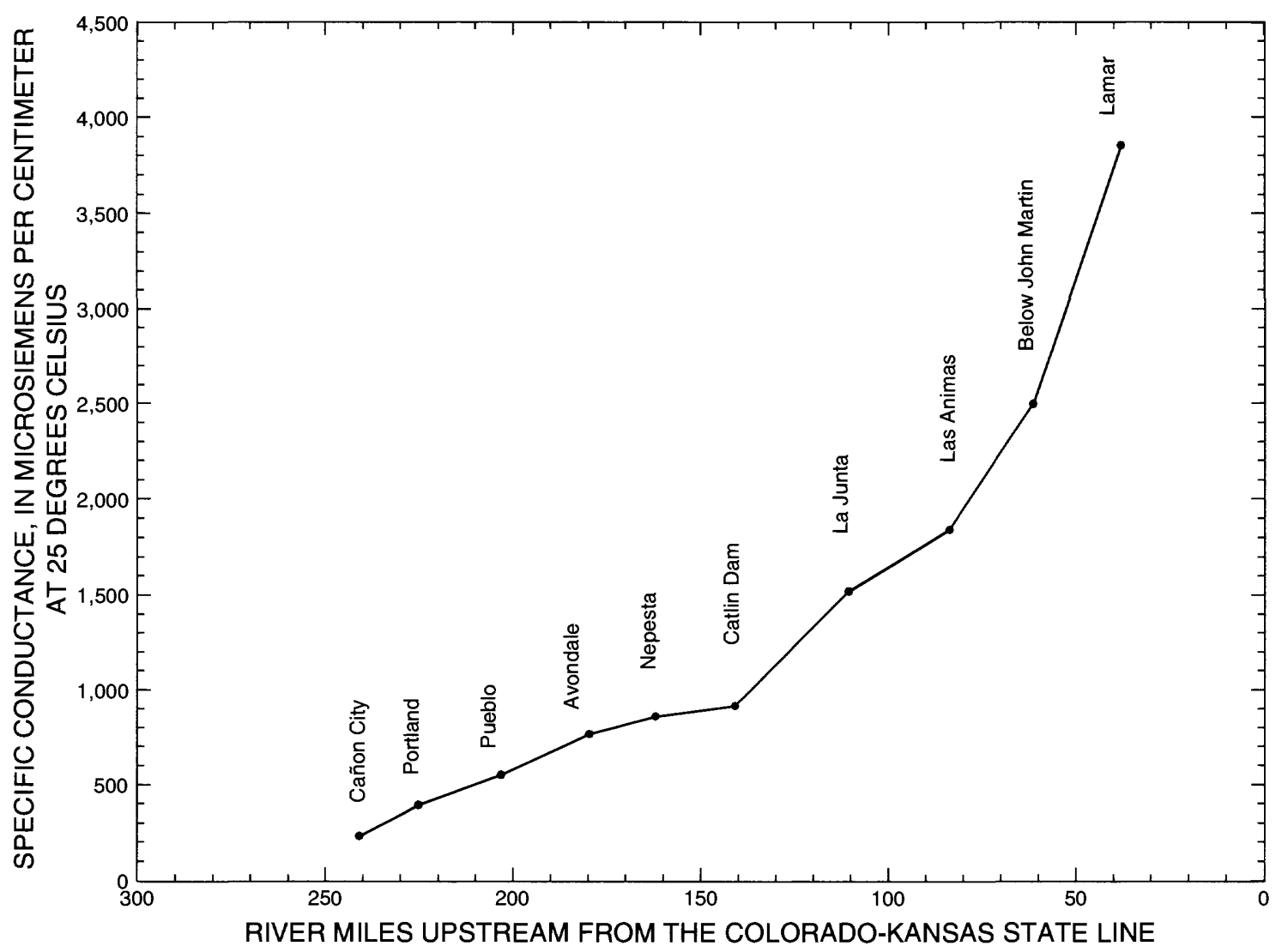

Figure 4. Median specific conductance at selected sites on the Arkansas River, 1990-93.

flow when natural base flow was supplemented by reservoir releases in the upper basin. Daily mean streamflow decreased significantly in July, August, and September (table 2).

The monthly streamflow trends probably were caused by differences in the quantity of imported western-slope water for the two periods of analysis. The transmountain importation of Colorado River Basin water into the Arkansas River Basin has occurred since the late 1800's. The imported water has been used to meet mining, agricultural, municipal, and industrial water needs. Some of the imported water is diverted directly into the main stem of the upper Arkansas River, and some of the water is diverted out of the upper basin via closed conduit flow. During 1964-74, prior to the completion of Pueblo Reservoir, the median annual volume of water that was imported into the Arkansas River Basin and released to the river was about 62,900 acre-ft (fig. 6). The median annual volume of imported water increased significantly $(\mathrm{p}=0.01)$ to about 103,000 acre-ft during 1975-94 (fig. 6). These values do not include une water that was diverted out of the basin via closed conduit flow. The increase in transmountain water is attributable to the Fryingpan-Arkansas Project importations, which began in 1972. The increased importation of westernslope water and the release of this water from storage during otherwise low-flow months probably accounts for the increase in streamflow at Cañon City during October-April. Water is released from upper basin storage in the winter to create storage space for additional transmountain imports during the coming snowmelt runoff season. There were insufficient data for a historical analysis of monthly trends in the amount of transmountain water that has been released to the Arkansas River.

Although there is a 13-year gap (1977-89) in the specific-conductance record, the data do provide some important information about the quality of water that entered the lower basin before and after the construction of Pueblo Reservoir. A visual assessment of the data indicates that the range of specificconductance values $(130-380 \mu \mathrm{S} / \mathrm{cm})$ was relatively constant during 1964-94 (fig. 7). The median specific conductance decreased about 19 percent from $307 \mu \mathrm{S} / \mathrm{cm}$ in $1964-74$ to $250 \mu \mathrm{S} / \mathrm{cm}$ in $1975-94$. 


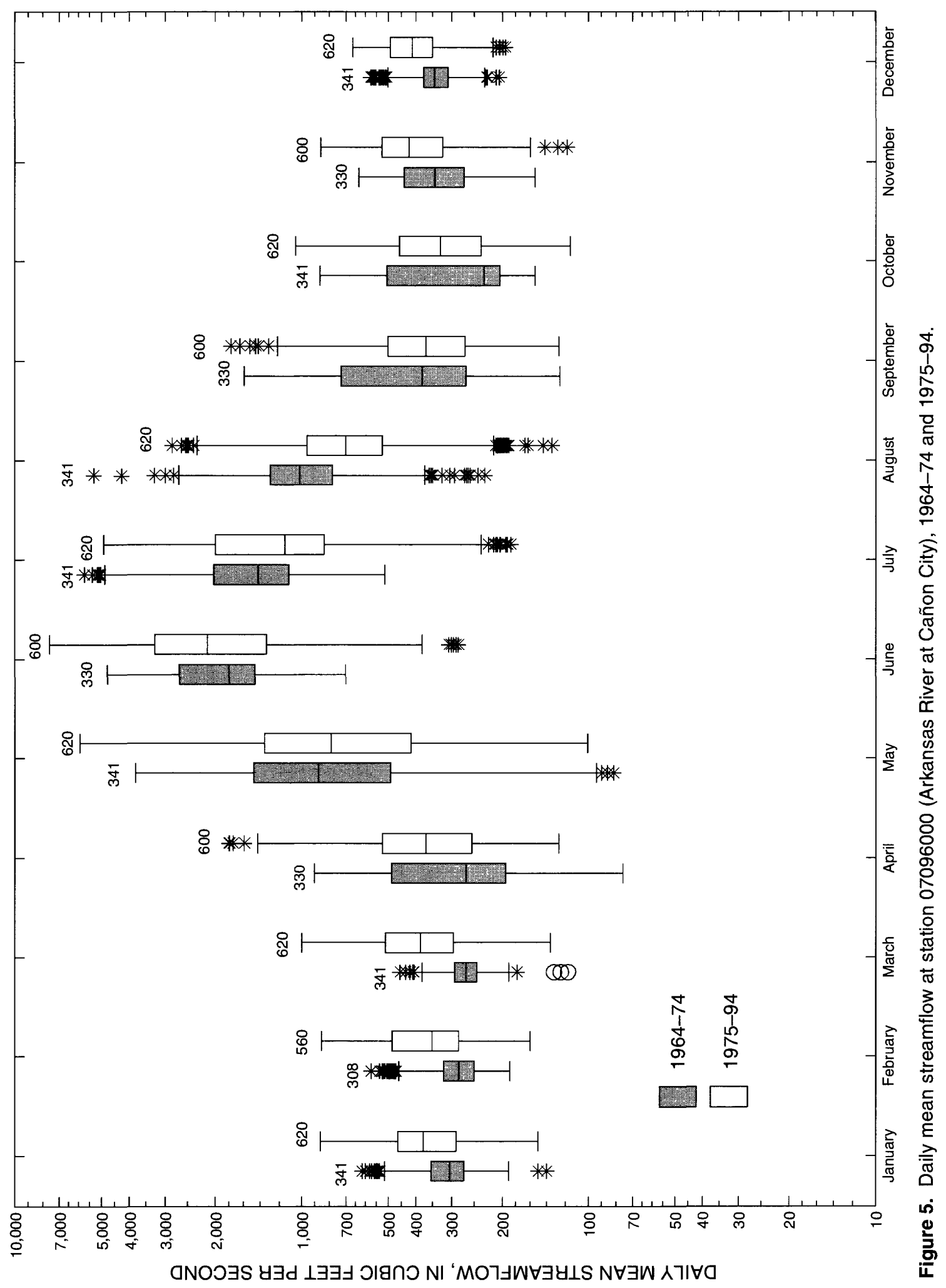


Table 2. Step-trend results on the daily mean streamflow at station 07096000 (Arkansas River at Cañon City) between 1964-74 and 1975-94

$\left[\mathrm{ft}^{3} / \mathrm{s}\right.$, cubic feet per second; $\mathrm{N}$, number of values; $\mathrm{p}$ value is the significance level of the test; <, less than; NS, trend not statistically significant; $\mathrm{I}$, statistically significant increasing trend; D, statistically significant decreasing trend]

\begin{tabular}{|c|c|c|c|c|c|c|}
\hline \multirow[b]{2}{*}{ Month } & \multicolumn{2}{|c|}{$1964-74$} & \multicolumn{2}{|c|}{$1975-94$} & \multirow[b]{2}{*}{$p$ value } & \multirow[b]{2}{*}{ Significance $^{1}$} \\
\hline & $\begin{array}{c}\text { Median } \\
\text { streamflow } \\
\left(\mathrm{ft}^{3} / \mathrm{s}\right)\end{array}$ & $\mathbf{N}$ & $\begin{array}{c}\text { Median } \\
\text { streamflow } \\
\left(\mathrm{ft}^{3} / \mathrm{s}\right)\end{array}$ & $\mathbf{N}$ & & \\
\hline January & 304 & 341 & 378 & 620 & $<0.01$ & I \\
\hline February & 284 & 308 & 351 & 560 & $<.01$ & I \\
\hline March & 268 & 341 & 385 & 620 & $<.01$ & I \\
\hline May & 874 & 341 & 792 & 620 & .16 & NS \\
\hline June & 1,800 & 330 & 2,140 & 600 & .04 & I \\
\hline July & 1,420 & 341 & 1,150 & 620 & $<.01$ & $\mathrm{D}$ \\
\hline August & 1,020 & 341 & 703 & 620 & $<.01$ & $\mathrm{D}$ \\
\hline September & 380 & 330 & 369 & 600 & .04 & $\mathrm{D}$ \\
\hline
\end{tabular}

${ }^{1} \mathrm{~A}$ statistically significant trend was defined as having a $\mathrm{p}$ value less than or equal to 0.05 .

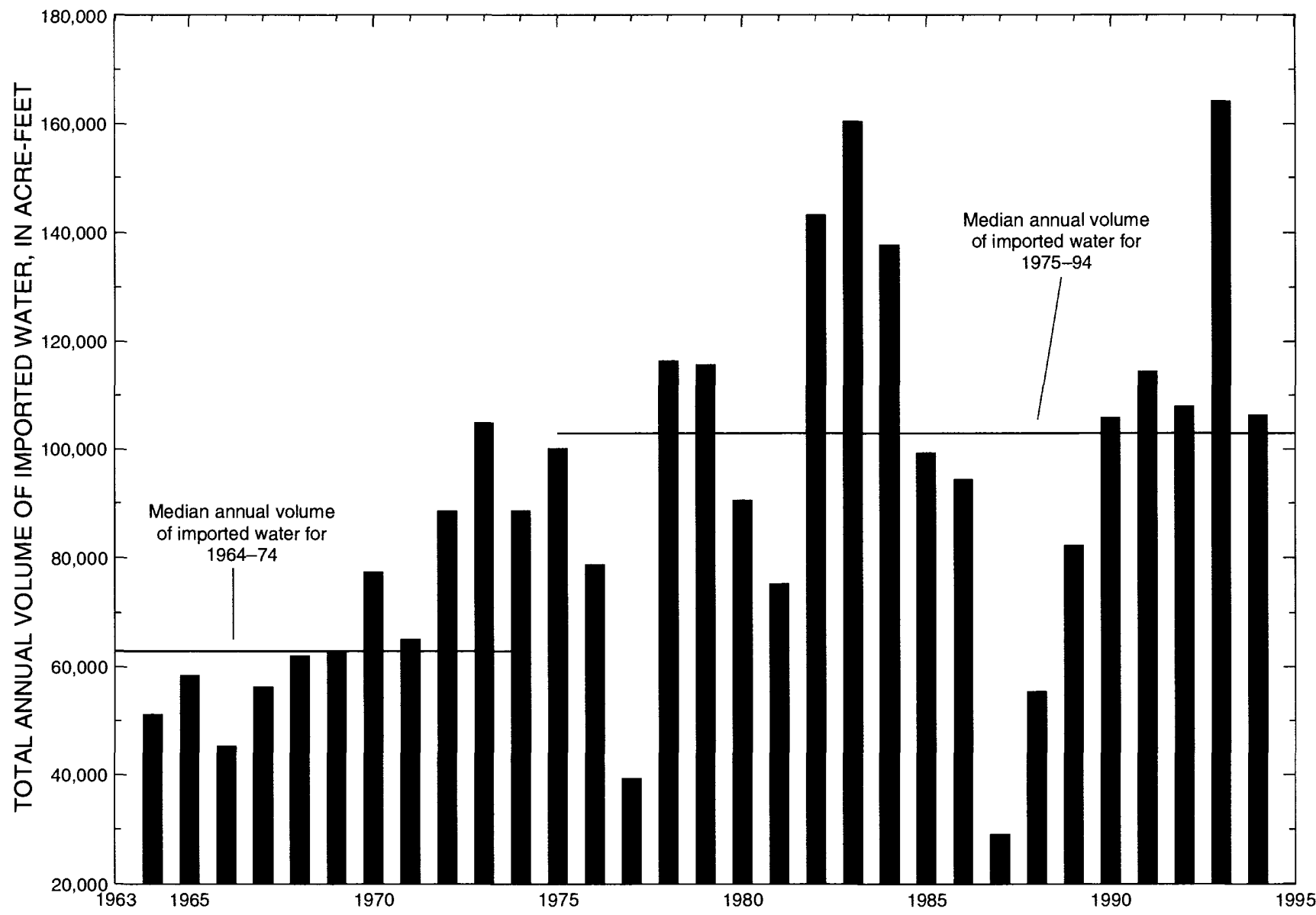

Figure 6. Total annual volume of water imported into the Arkansas River from the Colorado River Basin, 1964-94. 


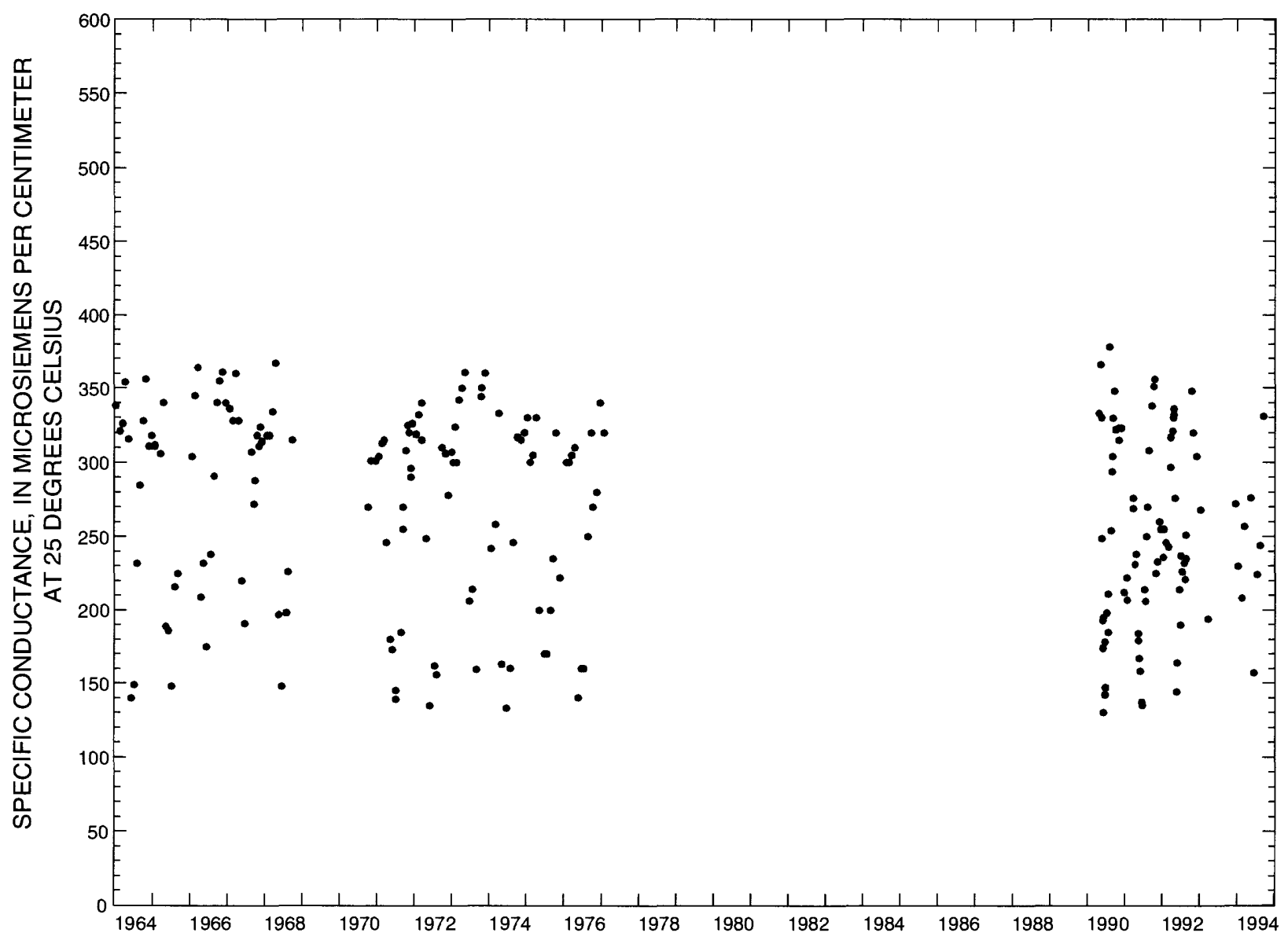

Figure 7. Specific conductance at station 07096000 (Arkansas River at Cañon City), 1964-94.

Boxplots of monthly specific-conductance data for 1964-74 and 1975-94 indicate that, after 1974, the median specific conductance tended to decrease during most low-flow months and increase during late summer (fig. 8), thus correlating well with the monthly streamflow trends. Specific conductance decreased significantly in January, February, and March (table 3), which are months having low streamflow. Although specific conductance tended to increase during July through September (fig. 8), the differences were not statistically significant (table 3 ).

The significant increase in streamflow and the significant decrease in specific conductance for January, February, and March probably were caused by an increase in the amount of stored imported water that was released to the river, upstream from Cañon City, during low flow. The larger flow volume increased the dilution potential of the river during a period when base flow, which has a larger dissolved-solids concentration and specific conductance than the imported water, historically represented a substantial part of the streamflow.

\section{Above Pueblo}

The quality of water in the Arkansas River above Pueblo (station 07099400) is important from a drinking-water perspective because the river is the municipal water supply for the Pueblo Board of Water Works and for the St. Charles Mesa Water District. The diversion point for the Pueblo water supply is about 4 mi downstream from station 07099400 (fig. 1), and the diversion point for the St. Charles Mesa water supply is about $8.5 \mathrm{mi}$ downstream from the station. Streamflow and specific-conductance data were available at station 07099400 for 29 years from 1966 through 1994. 


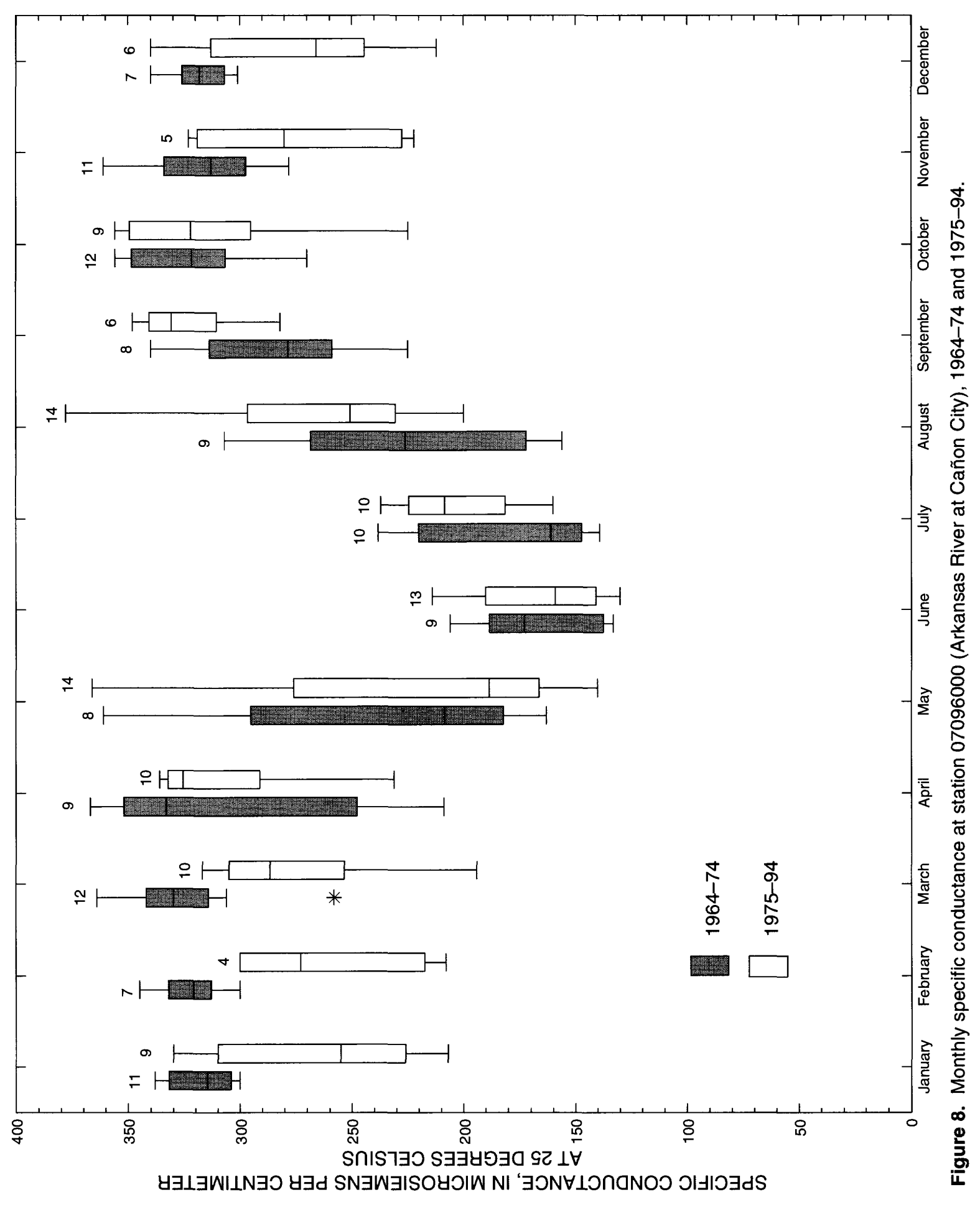


Table 3. Step-trend results on specific conductance at station 07096000 (Arkansas River at Cañon City) between 1964-74 and 1975-94

$[\mu \mathrm{S} / \mathrm{cm}$, microsiemens per centimeter at 25 degrees Celsius; $\mathrm{N}$, number of values; $\mathrm{p}$ value is the significance level of the test; <, less than; NS, trend not statistically significant; D, statistically significant decreasing trend]

\begin{tabular}{|c|c|c|c|c|c|c|}
\hline \multirow[b]{2}{*}{ Month } & \multicolumn{2}{|c|}{$1964-74$} & \multicolumn{2}{|c|}{ 1975-94 } & \multirow[b]{2}{*}{$p$ value } & \multirow[b]{2}{*}{ Significance ${ }^{1}$} \\
\hline & $\begin{array}{c}\text { Median } \\
\text { specific } \\
\text { conductance } \\
(\mu \mathrm{S} / \mathrm{cm})\end{array}$ & $\mathbf{N}$ & $\begin{array}{c}\text { Median } \\
\text { specific } \\
\text { conductance } \\
(\mu \mathrm{S} / \mathrm{cm})\end{array}$ & $\mathbf{N}$ & & \\
\hline January & 312 & 11 & 255 & 9 & 0.03 & $\bar{D}$ \\
\hline February & 321 & 7 & 273 & 4 & .02 & D \\
\hline March & 334 & 12 & 276 & 10 & $<.01$ & $\mathrm{D}$ \\
\hline April & 333 & 9 & 326 & 10 & .33 & NS \\
\hline May & 208 & 8 & 188 & 14 & .52 & NS \\
\hline June & 173 & 9 & 158 & 13 & .87 & NS \\
\hline July & 161 & 10 & 208 & 10 & .17 & NS \\
\hline August & 226 & 9 & 250 & 14 & .06 & NS \\
\hline September & 278 & 8 & 330 & 6 & .11 & NS \\
\hline October & 322 & 12 & 322 & 9 & .97 & NS \\
\hline November & 311 & 11 & 280 & 5 & .19 & NS \\
\hline December & 318 & 7 & 266 & 6 & .06 & NS \\
\hline
\end{tabular}

${ }^{1}$ A statistically significant trend was defined as having a $\mathrm{p}$ value less than or equal to 0.05 .

The median annual streamflow at station 07099400 increased from about 445,200 acre-ft/yr in $1966-74$ to about 518,400 acre-ft/yr in $1975-94$; the difference in the median annual streamflow was not statistically significant $(\mathrm{p}=0.23)$. Although there was no significant change in the median annual streamflow, there were differences in the daily mean streamflow that were segregated by month in each of the two periods (fig. 9). Following the construction of Pueblo Reservoir, the daily mean streamflow increased significantly in March, April, June, July, September, and October (table 4). Most of the increases occurred during the growing season when demands for irrigation water were largest. Significant decreases in streamflow occurred in January, February, May, November, and December (table 4). This basic pattern of increased spring, summer, and fall streamflow and decreased winter streamflow is largely attributable to the WWSP. As discussed in the "Pueblo Reservoir" section, the WWSP allows irrigators to store water in Pueblo Reservoir from November 15 to March 15. This stored water usually is released to the river to meet downstream irrigation needs during early spring and the latter parts of the growing season when streamflow generally is insufficient to meet irrigation needs. The net effect of this operation downstream from Pueblo Reservoir is decreased streamflow in November through February and increased streamflow during early spring and late summer or autumn.

Specific conductance at station 07099400 has changed markedly since the construction of Pueblo Reservoir (fig. 10). The median specific conductance decreased significantly $(\mathrm{p}<0.01)$ from $625 \mu \mathrm{S} / \mathrm{cm}$ in $1966-74$ to $496 \mu \mathrm{S} / \mathrm{cm}$ in $1975-94$. The most obvious change in specific conductance was a narrowing of the range in specific conductance that occurred after 1974. Since 1974, the annual maximum specific conductance has tended to decrease, and the annual minimum specific conductance has tended to increase slightly. The annual maximum specific conductance decreased from a range of about 800 to more than $1,000 \mu \mathrm{S} / \mathrm{cm}$ in $1966-74$ to a range of about 500 to $750 \mu \mathrm{S} / \mathrm{cm}$ in 1975-94. Specific conductance tended to decrease during low flow, September through April, and increase during high flow, May through August (fig. 11). 


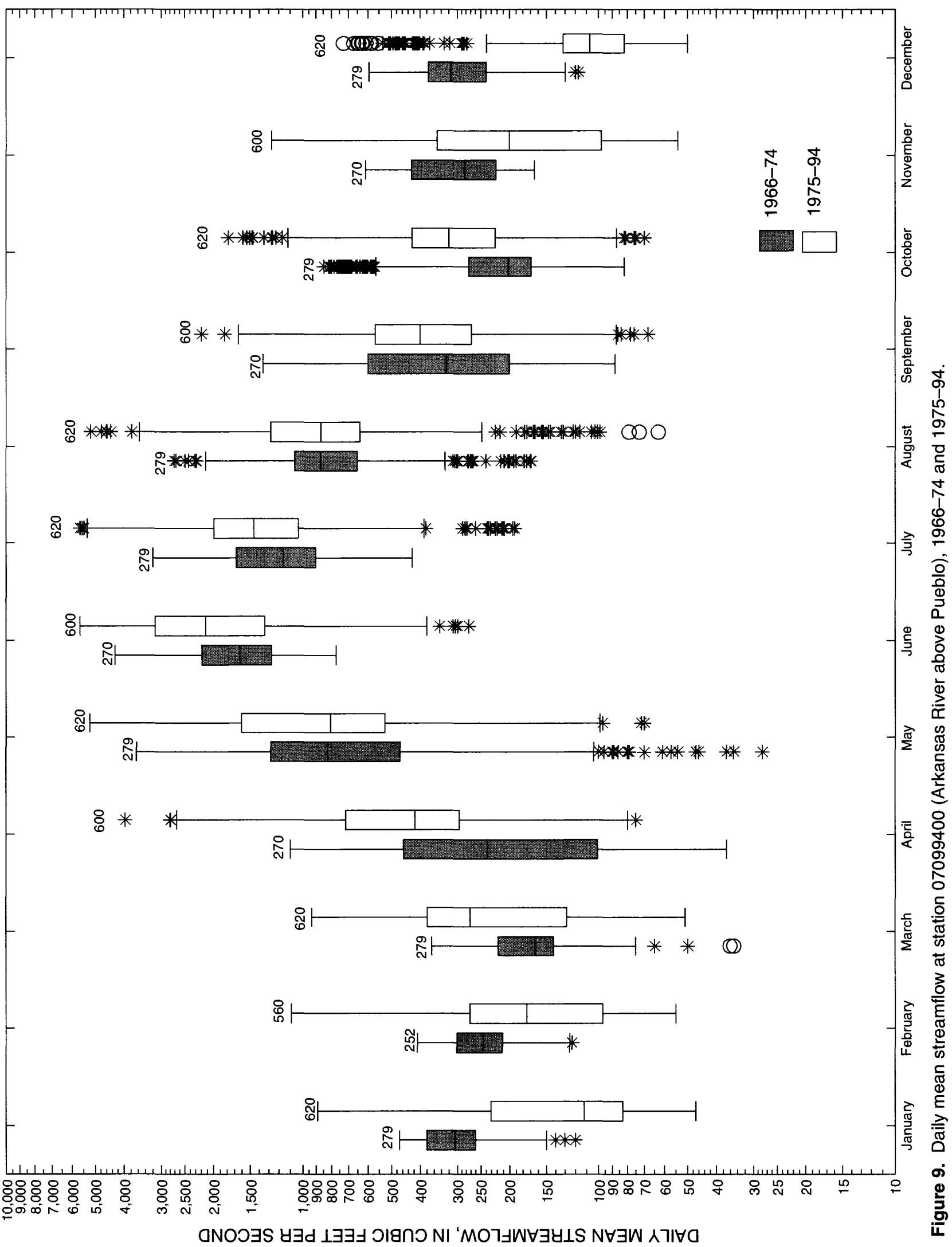


Table 4. Step-trend results on the daily mean streamflow at station 07099400 (Arkansas River above Pueblo) between 1966-74 and 1975-94

$\left[\mathrm{ft}^{3} / \mathrm{s}\right.$, cubic feet per second; $\mathrm{N}$, number of values; $\mathrm{p}$ value is the significance level of the test; <, less than; NS, trend not statistically significant; I, statistically significant increasing trend; D, statistically significant decreasing trend]

\begin{tabular}{|c|c|c|c|c|c|c|}
\hline \multirow[b]{2}{*}{ Month } & \multicolumn{2}{|c|}{$1966-74$} & \multicolumn{2}{|c|}{$1975-94$} & \multirow[b]{2}{*}{$p$ value } & \multirow[b]{2}{*}{ Significance $^{1}$} \\
\hline & $\begin{array}{c}\text { Median } \\
\text { streamflow } \\
\left(\mathrm{ft}^{3} / \mathrm{s}\right)\end{array}$ & $\mathbf{N}$ & $\begin{array}{c}\text { Median } \\
\text { streamflow } \\
\left(\mathrm{ft}^{3} / \mathrm{s}\right)\end{array}$ & $\mathbf{N}$ & & \\
\hline January & 300 & 279 & 112 & 620 & $<0.01$ & $\mathrm{D}$ \\
\hline February & 245 & 252 & 175 & 560 & $<.01$ & D \\
\hline March & 164 & 279 & 271 & 620 & $<.01$ & I \\
\hline May & 824 & 279 & 806 & 620 & .03 & $\mathrm{D}$ \\
\hline June & 1,625 & 270 & 2,120 & 600 & $<.01$ & I \\
\hline July & 1,160 & 279 & 1,460 & 620 & $<.01$ & I \\
\hline August & 867 & 279 & 866 & 620 & .16 & NS \\
\hline September & 326 & 270 & 400 & 600 & $<.01$ & I \\
\hline
\end{tabular}

${ }^{1}$ A statistically significant trend was defined as having a $\mathrm{p}$ value less than or equal to 0.05 .

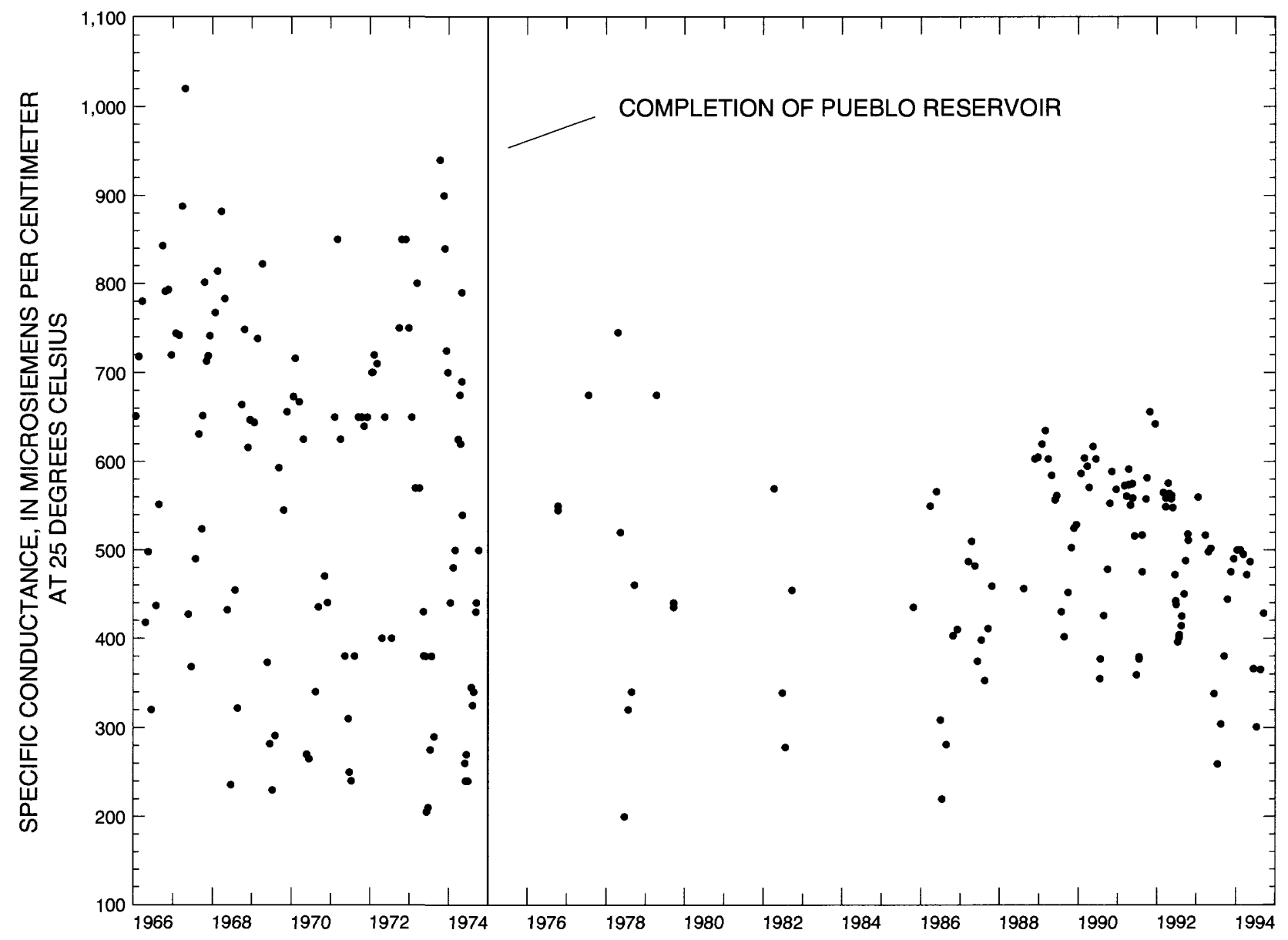

Figure 10. Specific conductance at station 07099400 (Arkansas River above Pueblo), 1966-94. 


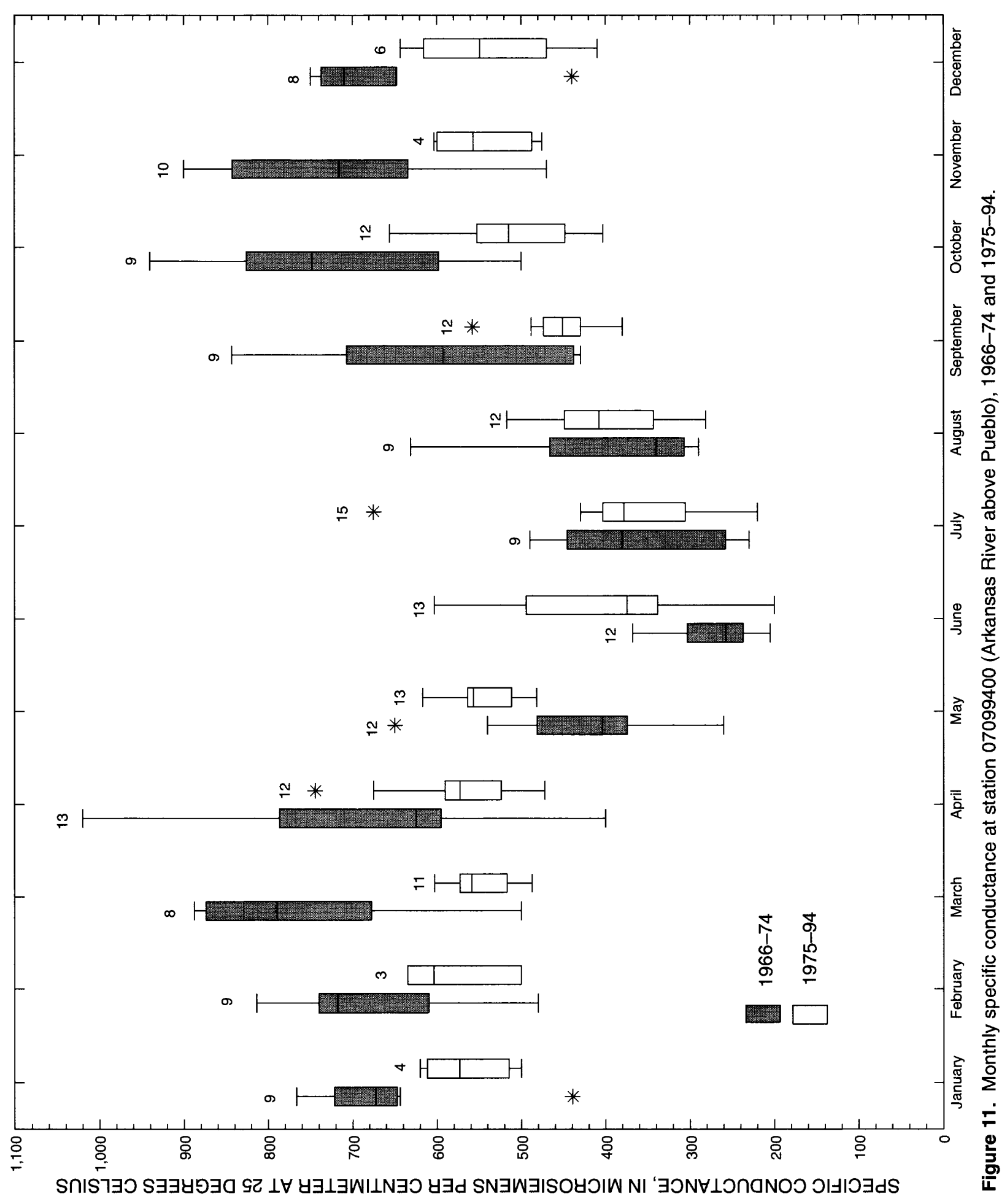


These differences in specific conductance were statistically significant for January, March-June, and September-December (table 5). On a seasonal basis, the median specific conductance increased from $460 \mu \mathrm{S} / \mathrm{cm}$ in $1966-74$ to $465 \mu \mathrm{S} / \mathrm{cm}$ in 1975-94; the increase was not statistically significant $(\mathrm{p}=0.51)$ during the growing season. In the winterstorage season, the median specific conductance decreased significantly $(\mathrm{p} \leq 0.01)$ from $720 \mu \mathrm{S} / \mathrm{cm}$ in $1966-74$ to $575 \mu \mathrm{S} / \mathrm{cm}$ in $1975-94$. Historically, before the construction of Pueblo Reservoir, specific conductance was highest during low streamflow in the winter. With completion of the dam, the high-specificconductance inflow (October-April) began to mix with and be diluted in the reservoir by lower specificconductance water derived from snowmelt runoff, resulting in decreased specific-conductance water flowing out of the reservoir during low flow. A decrease in the specific conductance of the reservoir inflow, as indicated by the 19-percent decrease in the median specific conductance at Cañon City, also contributed to the decreased specific conductance at station 07099400. Additionally, before the completion of Pueblo Dam, the annual minimum specific conductance occurred during high flow, May through August. Following the closure of Pueblo Dam, the specific conductance at station 07099400 increased during high flow probably because of mixing of low-specificconductance inflow from snowmelt runoff with higher specific-conductance water in the reservoir (fig. 11).

Estimates were made of the frequency of occurrence of specific-conductance values at station 07099400 and at the diversion points for the domestic water supplies for the Pueblo Board of Water Works and the St. Charles Mesa Water District. This information and the observed relations between specific conductance and dissolved-solids concentration were used to estimate the percentage of time the dissolved-solids concentration exceeded the SMCL for drinking water $(500 \mathrm{mg} / \mathrm{L})$. A comparison of specific-conductance data that have been collected at station 07099400 with data that have been collected at the diversion points for the Pueblo Board of Water Works and the St. Charles Mesa Water District indicates that specific conductance increases about 3 percent per mile in that reach. An estimate was made, based on this relation, of the specific conductance at the diversion points for the two domestic water supplies (fig. 12). These estimates were made by increasing the specific conductance at station 07099400 by 12 percent for the diversion for the Pueblo Board of Water Works and by 27 percent for the diversion for the St. Charles Mesa Water District.

Table 5. Step-trend results on specific conductance at station 07099400 (Arkansas River above Pueblo) between 1966-74 and 1975-94

$[\mu \mathrm{S} / \mathrm{cm}$, microsiemens per centimeter at 25 degrees Celsius; $\mathrm{N}$, number of values; $\mathrm{p}$ value is the significance level of the test; <, less than; NS, trend not statistically significant; I, statistically significant increasing trend; D, statistically significant decreasing trend]

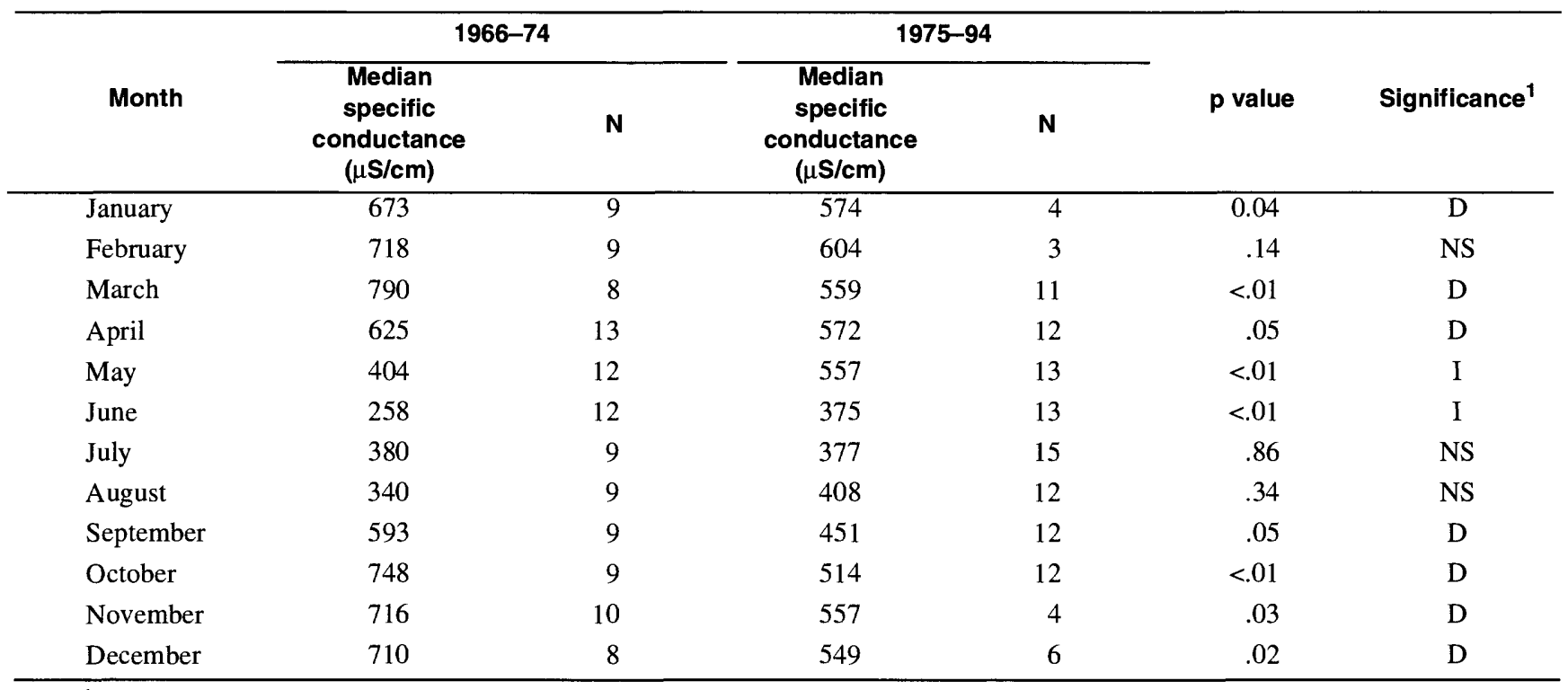

\footnotetext{
${ }^{1}$ A statistically significant trend was defined as having a p value less than or equal to 0.05 .
} 

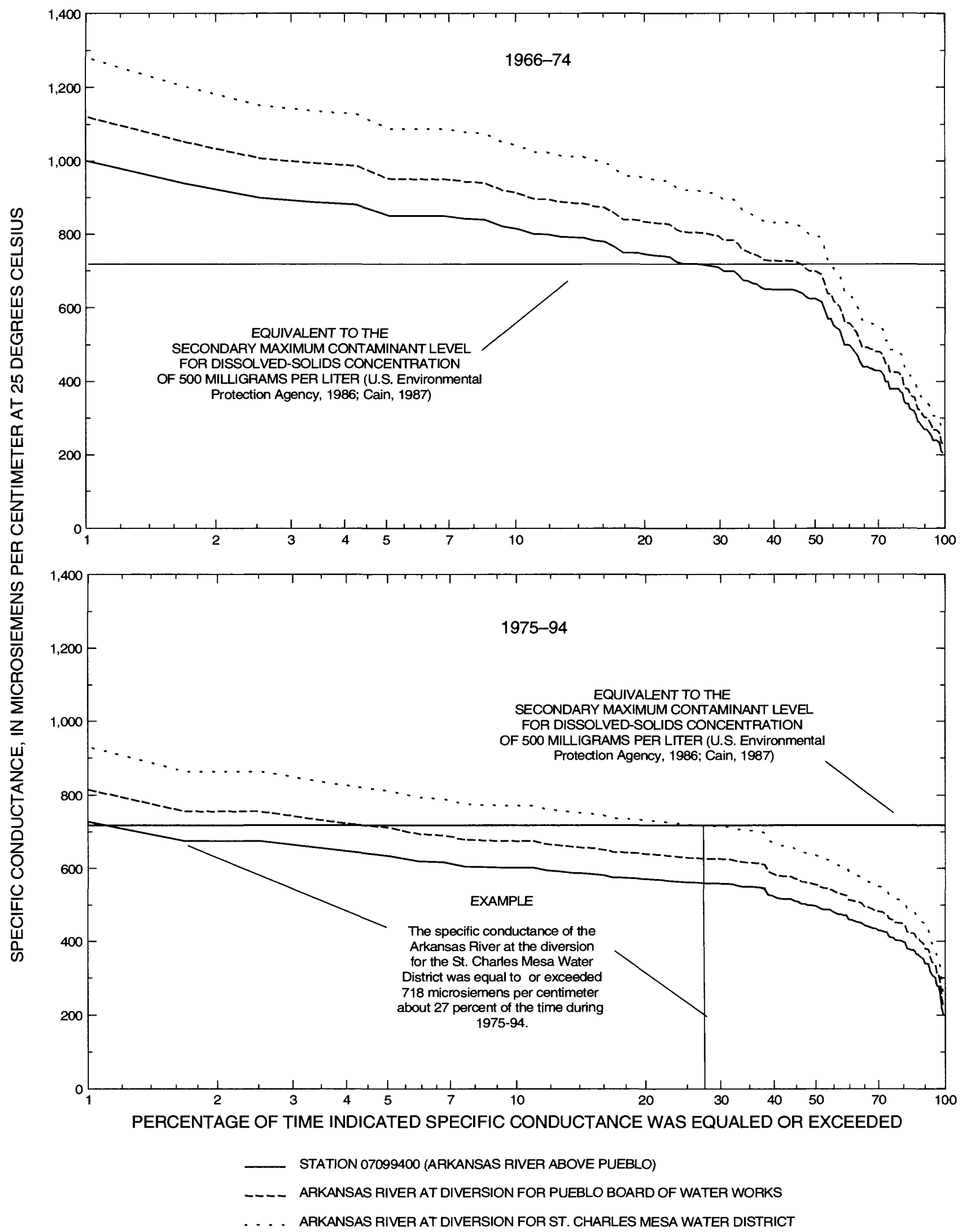

Figure 12. Duration frequency of specific conductance at station 07099400 (Arkansas River above Pueblo); Arkansas River at diversion for the Pueblo Board of Water Works; and Arkansas River at diversion for the St. Charles Mesa Water District, 1966-74 and 1975-94. 
Cain (1987) determined, using regression analysis, that a specific conductance of $718 \mu \mathrm{S} / \mathrm{cm}$ at station 07099400 was equivalent to a dissolvedsolids concentration of $500 \mathrm{mg} / \mathrm{L}$. The conversion also was assumed to be applicable at the two watersupply diversion points. Therefore, the dissolvedsolids concentration at station 07099400 and at the two water-supply diversion points was estimated to exceed $500 \mathrm{mg} / \mathrm{L}$ when specific conductance exceeded $718 \mu \mathrm{S} / \mathrm{cm}$. During 1966-74, the estimated exceedance of a specific conductance of $718 \mu \mathrm{S} / \mathrm{cm}$ was 28 percent at station 07099400,45 percent at the Pueblo Board of Water Works diversion, and 55 percent at the St. Charles Mesa Water District diversion point. During 1975-94, after the construction of Pueblo Reservoir, the exceedance of a specific conductance of $718 \mu \mathrm{S} / \mathrm{cm}$ decreased to about 1 percent at station 07099400, 4.3 percent at the Pueblo Board of Water Works diversion, and 27 percent at the St. Charles Mesa Water District diversion point (fig. 12). These results indicate that the chemical quality of the Arkansas River, in terms of specific conductance and dissolved-solids concentration, has improved in the 8.5-mi reach between Pueblo Reservoir and the St. Charles Mesa Water District diversion since 1975, when Pueblo Reservoir was completed. The improved quality of water is attributable to two factors: (1) Decreased specific conductance in the upper Arkansas River, probably because of the increased importation of Colorado River Basin water; and (2) dilution of reservoir inflow having elevated specific conductance during low flow by low-specific-conductance water in Pueblo Reservoir.

\section{Near Avondale}

The largest main-stem streamflow in the Arkansas River occurs at station 07109500 (Arkansas River near Avondale) (fig. 1) because of substantial tributary inflow from the St. Charles River and Fountain Creek and because the station is upstream from most of the large irrigation canals that divert most of the flow from the lower Arkansas River. Streamflow at station 07109500 is strongly affected by Pueblo Reservoir operations because of the proximity of the station to Pueblo Reservoir and because of the absence of substantial streamflow diversions between the reservoir and the station. In terms of water quality, most of the concern and focus at this station are related to specific conductance and the suitability of the river as an irrigation supply. Streamflow and specificconductance data were available at station 07109500 for 1969-94.

The median annual streamflow in 1969-74 $(623,000 \mathrm{acre}-\mathrm{ft} / \mathrm{yr})$ was not significantly different $(\mathrm{p}=0.65)$ from the median annual streamflow in 1975-94 (625,200 acre-ft/yr). Similarly, the median annual streamflow from the upper basin in 1969-74 (535,700 acre-ft/yr) and 1975-94 (538,600 acre-ft/yr), as indicated by the record at station 07096000 , was not significantly different $(\mathrm{p}=0.69)$. The temporal nature of streamflow, however, changed appreciably during the two periods (fig. 13). After the completion of Pueblo Reservoir (1975), streamflow generally increased during March through October and decreased during November through February (fig. 13). The decreases in daily mean streamflow during November through February were all statistically significant; streamflow increased significantly during March, April, June, August, and October (table 6). The decreased winter streamflow was caused by the storage of water in Pueblo Reservoir as part of the WWSP. As previously noted in the "Pueblo Reservoir" section, the median annual volume of water stored in Pueblo Reservoir during 1975-94 as part of the WWSP was 42,200 acre-ft. The significant increase in streamflow during March, April, June, August, and October is attributable to the combined effects of the release of stored WWSP water from Pueblo Reservoir and increased inflow from Fountain Creek. The median annual streamflow at the tributary station 07106500 (Fountain Creek at Pueblo) increased from about 37,000 acre-ft/yr in 1969-74 to about $67,000 \mathrm{acre}-\mathrm{ft} / \mathrm{yr}$ in $1975-94$. The median daily streamflow of Fountain Creek at Pueblo during March through October increased 50 percent from about $48 \mathrm{ft}^{3} / \mathrm{s}$ in 1969-74 to about $72 \mathrm{ft}^{3} / \mathrm{s}$ in 1975-94. This increase in streamflow likely is partly attributable to increased unit runoff and increased municipal wastewater discharge from the Colorado Springs area. Increased unit runoff probably has resulted from the substantial growth and the associated paving of permeable surfaces in the greater Colorado Springs area. Much of the flow in Fountain Creek is derived from sewered (treated wastewater effluent) and unsewered (lawn irrigation) wastewater from Colorado Springs and several smaller municipalities in El Paso County (Edelmann and Cain, 1985). 


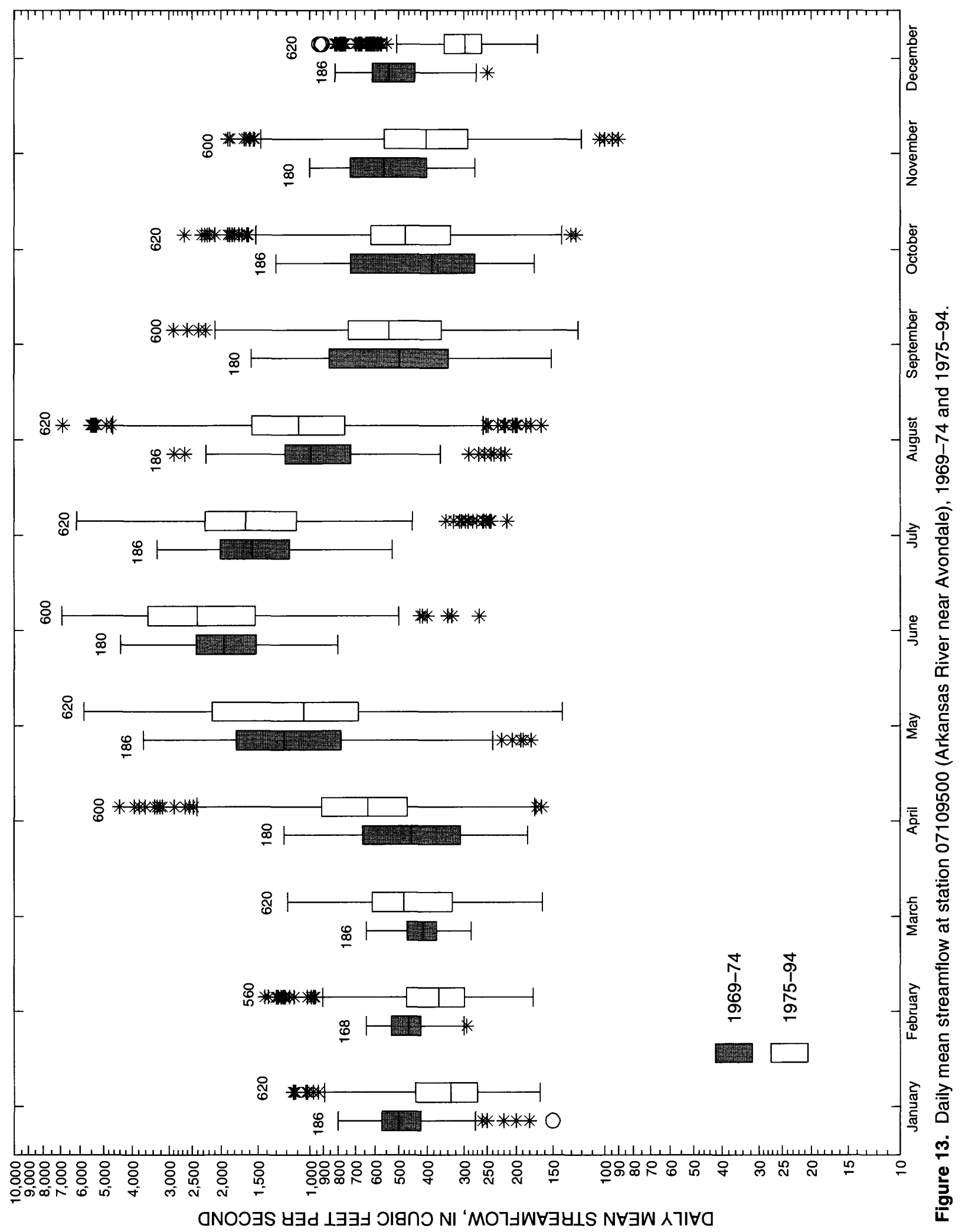


Table 6. Step-trend results on the daily mean streamflow at station 07109500 (Arkansas River near Avondale) between 1969-74 and 1975-94

$\left[\mathrm{ft}^{3} / \mathrm{s}\right.$, cubic feet per second; $\mathrm{N}$, number of values; $\mathrm{p}$ value is the significance level of the test; <, less than; NS, trend not statistically significant; I, statistically significant increasing trend; D, statistically significant decreasing trend]

\begin{tabular}{|c|c|c|c|c|c|c|}
\hline \multirow[b]{2}{*}{ Month } & \multicolumn{2}{|c|}{ 1969-74 } & \multicolumn{2}{|c|}{$1975-94$} & \multirow[b]{2}{*}{$p$ value } & \multirow[b]{2}{*}{ Significance $^{1}$} \\
\hline & $\begin{array}{l}\text { Median } \\
\text { streamflow } \\
\left(\mathrm{ft}^{3} / \mathrm{s}\right)\end{array}$ & $\mathbf{N}$ & $\begin{array}{c}\text { Median } \\
\text { streamflow } \\
\left(\mathrm{ft}^{3} / \mathrm{s}\right)\end{array}$ & $\mathbf{N}$ & & \\
\hline January & 500 & 186 & 332 & 620 & $<0.01$ & $\bar{D}$ \\
\hline February & 462 & 168 & 365 & 560 & $<.01$ & D \\
\hline March & 414 & 186 & 480 & 620 & $<.01$ & I \\
\hline April & 452 & 180 & 636 & 600 & $<.01$ & I \\
\hline May & 1,220 & 186 & 1,050 & 620 & .73 & NS \\
\hline June & 1,950 & 180 & 2,410 & 600 & $<.01$ & I \\
\hline July & 1,560 & 186 & 1,650 & 620 & .09 & NS \\
\hline August & 993 & 186 & 1,090 & 620 & $<.01$ & I \\
\hline September & 497 & 180 & 540 & 600 & .40 & NS \\
\hline October & 386 & 186 & 472 & 620 & .04 & I \\
\hline November & 560 & 180 & 403 & 600 & $<.01$ & $\mathrm{D}$ \\
\hline December & 540 & 186 & 298 & 620 & $<.01$ & $\mathrm{D}$ \\
\hline
\end{tabular}

${ }^{1}$ A statistically significant trend was defined as having a $p$ value less than or equal to 0.05 .

From 1969 to 1995, the discharge from the Colorado Springs wastewater-treatment plant increased from about $25 \mathrm{ft}^{3} / \mathrm{s}$ to about $50 \mathrm{ft}^{3} / \mathrm{s}$ (V.L. Card, Colorado Springs Utilities, written commun., 1996; Edelmann and Cain, 1985). Although the median daily streamflow of Fountain Creek at Pueblo during November through February increased from about $63 \mathrm{ft}^{3} / \mathrm{s}$ in $1969-74$ to about $87 \mathrm{ft}^{3} / \mathrm{s}$ in $1975-94$, the increase was not large enough to offset the seasonal decrease in streamflow of the Arkansas River at Avondale, which resulted from the storage of WWSP water in Pueblo Reservoir.

Specific conductance at station $07109500 \mathrm{had}$ less variability between the pre-Pueblo Reservoir (1969-74) and post-Pueblo Reservoir (1975-94) periods (fig. 14) than specific conductance at the upstream station 07099400. Although the annual minimum and maximum specific conductance tended to increase after 1974, the median specific conductance for 1969-74 $(778 \mu \mathrm{S} / \mathrm{cm})$ was not significantly different ( $\mathrm{p}=0.16$ ) from the median specific conductance for 1975-94 $(812 \mu \mathrm{S} / \mathrm{cm})$. The annual minimum specific conductance increased from a range of about 200 to $400 \mu \mathrm{S} / \mathrm{cm}$ in $1969-74$ to a range of about 250 to $600 \mu \mathrm{S} / \mathrm{cm}$ in $1975-94$ (fig. 14). The annual maximum specific conductance increased from a range of about 1,000 to $1,100 \mu \mathrm{S} / \mathrm{cm}$ in $1969-74$ to a range of about 1,000 to $1,450 \mu \mathrm{S} / \mathrm{cm}$ in $1975-94$ (fig. 14). Monthly specific conductance differed between 1969-74 and 1975-94 (fig. 15), but most of the differences were not statistically significant (table 7). The small number of significant differences partly may be due to the small amount of specificconductance data in 1969-74 (table 7). On a seasonal basis, the median specific conductance in the growing season increased from $580 \mu \mathrm{S} / \mathrm{cm}$ in $1969-74$ to $700 \mu \mathrm{S} / \mathrm{cm}$ in 1975-94; the increase was not statistically significant $(\mathrm{p}=0.07)$. In the winter-storage season, the median specific conductance increased significantly $(\mathrm{p} \leq 0.01)$ from $900 \mu \mathrm{S} / \mathrm{cm}$ in $1969-74$ to $1,050 \mu \mathrm{S} / \mathrm{cm}$ in $1975-94$.

Significant increases in specific conductance occurred during June, August, and December (table 7). The increase in the median specific conductance in December ( 900 to $1,130 \mu \mathrm{S} / \mathrm{cm}$ ) coincided with a significant decrease in streamflow (table 6). The increased median specific conductance in June (338 to $455 \mu \mathrm{S} / \mathrm{cm}$ ) and in August (470 to $550 \mu \mathrm{S} / \mathrm{cm}$ ) coincided with significant increases in streamflow for those months (table 6). This relation between streamflow and specific-conductance trends is unusual because increased streamflow generally is expected to 


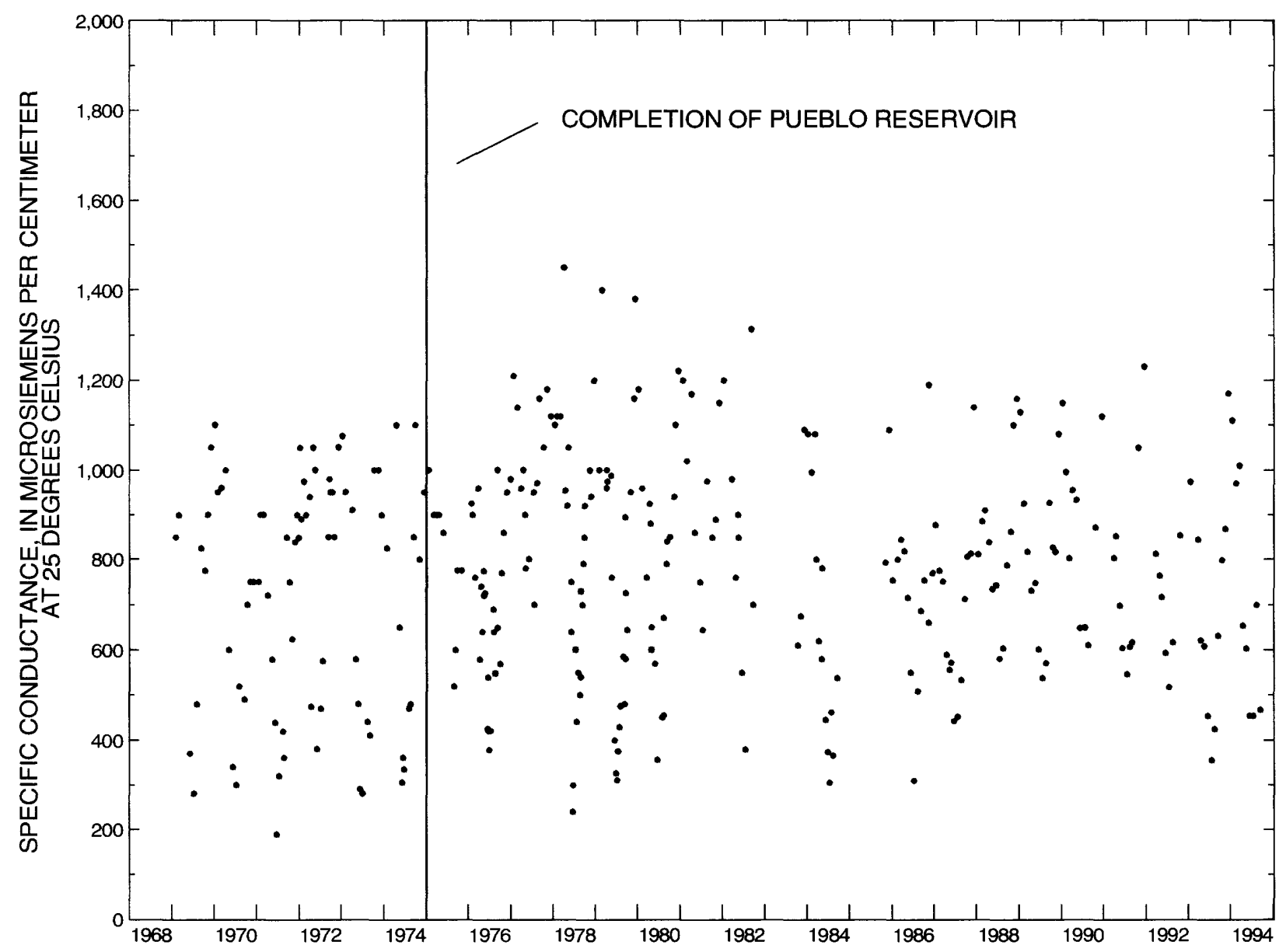

Figure 14. Specific conductance at station 07109500 (Arkansas River near Avondale), 1969-94.

result in increased dilution and decreased specific conductance. There are two likely causes of the increased specific conductance in June and August: (1) Mixing of low-specific-conductance and highspecific-conductance water in Pueblo Reservoir resulted in increased specific conductance in the reservoir outflow during months that historically had the lowest specific conductance, and (2) dissolved-solids loads from major tributaries increased. Apparently, both situations occurred and together caused increases in specific conductance during June and August. A lack of data prevented an analysis of streamflow and specific-conductance trends in the St. Charles River (fig. 1), which is tributary to the Arkansas River about 4.5 mi upstream from station 07109500. Adequate data did exist for general trend analysis at Fountain Creek (fig. 1), the other major tributary in the reach, although there were not enough data to do monthly trend analysis. The median specific conductance at station 07106500 (Fountain Creek at Pueblo) decreased from $1,500 \mu \mathrm{S} / \mathrm{cm}$ in $1969-74$ to $1,380 \mu \mathrm{S} / \mathrm{cm}$ in $1975-94$. Although specific conductance decreased in Fountain Creek at Pueblo, it remained substantially larger than specific conductance in the Arkansas River near Avondale. As previously mentioned in this section, the median annual streamflow at station 07106500 increased from about $37,000 \mathrm{acre}-\mathrm{ft} / \mathrm{yr}$ in $1969-74$ to about $67,000 \mathrm{acre}-\mathrm{ft} / \mathrm{yr}$ in 1975-94, with streamflow increasing during all seasons. The median specific conductance in Fountain Creek was converted to an equivalent dissolved-solids concentration based on relations described by Cain (1987). The estimated median dissolved-solids concentrations were multiplied by the median annual streamflow to obtain an estimate of the median annual dissolved-solids load contributed by Fountain Creek to the Arkansas River in 1969-74 and 1975-94. Based on these estimates, dissolved-solids loading increased about 58 percent from 53,000 to 84,000 tons/yr. 


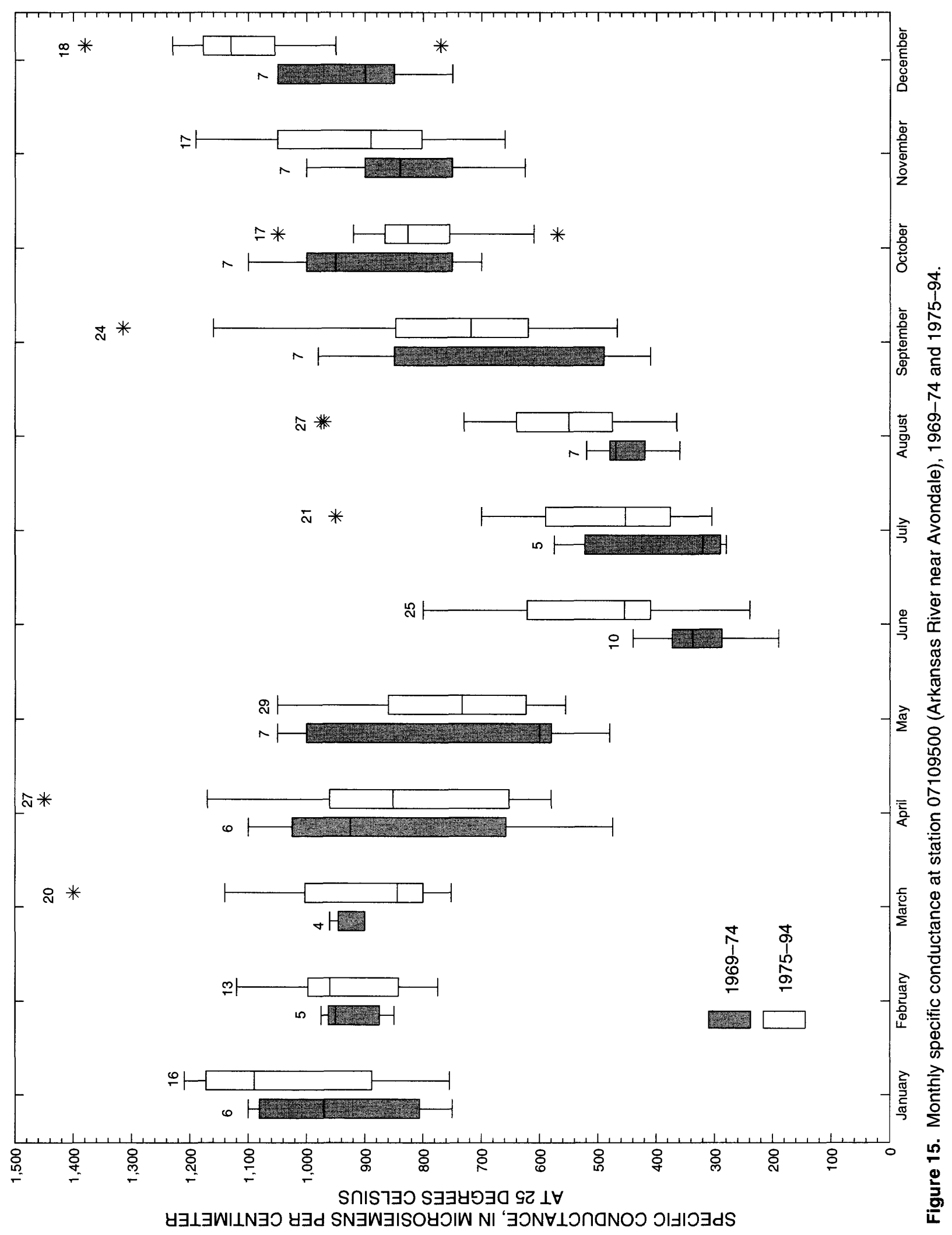


Table 7. Step-trend results on specific conductance at station 07109500 (Arkansas River near Avondale) between 1969-74 and 1975-94

$[\mu \mathrm{S} / \mathrm{cm}$, microsiemens per centimeter at 25 degrees Celsius; $\mathrm{N}$, number of values; $\mathrm{p}$ value is the significance level of the test; $<$, less than; NS, trend not statistically significant; I, statistically significant increasing trend]

\begin{tabular}{|c|c|c|c|c|c|c|}
\hline \multirow[b]{2}{*}{ Month } & \multicolumn{2}{|c|}{$1969-74$} & \multicolumn{2}{|c|}{ 1975-94 } & \multirow[b]{2}{*}{$p$ value } & \multirow[b]{2}{*}{ Significance $^{1}$} \\
\hline & $\begin{array}{c}\text { Median } \\
\text { specific } \\
\text { conductance } \\
(\mu \mathrm{S} / \mathrm{cm})\end{array}$ & $\mathbf{N}$ & $\begin{array}{c}\text { Median } \\
\text { specific } \\
\text { conductance } \\
(\mu \mathrm{S} / \mathrm{cm})\end{array}$ & $\mathbf{N}$ & & \\
\hline January & 970 & 6 & 1,090 & 16 & 0.17 & NS \\
\hline February & 950 & 5 & 960 & 13 & .66 & NS \\
\hline March & 900 & 4 & 844 & 20 & .56 & NS \\
\hline April & 925 & 6 & 852 & 27 & .66 & NS \\
\hline May & 600 & 7 & 734 & 29 & .38 & NS \\
\hline June & 338 & 10 & 455 & 25 & $<.01$ & I \\
\hline July & 320 & 5 & 454 & 21 & .15 & NS \\
\hline August & 470 & 7 & 550 & 27 & .01 & I \\
\hline September & 850 & 7 & 718 & 24 & .60 & NS \\
\hline October & 950 & 7 & 827 & 17 & .37 & NS \\
\hline November & 840 & 7 & 890 & 17 & .22 & NS \\
\hline December & 900 & 7 & 1,130 & 18 & $<.01$ & I \\
\hline
\end{tabular}

${ }^{1}$ A statistically significant trend was defined as having a $p$ value less than or equal to 0.05 .

The duration frequencies of specific conductance at station 07109500 for 1969-74 and 1975-94 were compared to the salinity-hazard classifications for irrigated crops (fig. 16). The salinity hazard is a relation developed by the U.S. Salinity Laboratory (Richards, 1954) that describes the qualitative effect of saline water on irrigated crops. The hazard is based on the specific conductance of the water and is divided into four classes of salinity hazard ranging from low (Class $\mathrm{C} 1$ ) to very high (Class C4). Water at station 07109500 generally was Class C2 or C3. Class C2 water $(250-750 \mu \mathrm{S} / \mathrm{cm})$ is defined as having a moderate salinity hazard and can be used on crops having a moderate salt tolerance without needing special irrigation practices for salinity control. Class C3 $(750-2,250 \mu \mathrm{S} / \mathrm{cm})$ is defined as having a high salinity hazard. The changes in specific conductance that occurred at station 07109500 after 1974 did not result in a substantial change in the salinity-hazard classification of the water (fig. 16).

\section{At Las Animas}

Station 07124000 (Arkansas River at Las Animas) is located about $120 \mathrm{mi}$ downstream from Pueblo Reservoir (fig. 1). Streamflow at this station is substantially smaller than at station 07109500 (fig. 3) because several large irrigation canals divert most of the streamflow in the 96-mi reach between the stations. Irrigation-return flow composes a substantial fraction of the streamflow at station 07124000 (Cain, 1987); therefore, the specific conductance is considerably higher than at upstream sites (fig. 4). Streamflow and specific-conductance data were available at station 07124000 for 1961-94.

The median annual streamflow at station 07124000 increased significantly $(\mathrm{p}=0.01)$ from $77,200 \mathrm{acre}-\mathrm{ft} / \mathrm{yr}$ in $1961-74$ to $149,400 \mathrm{acre}-\mathrm{ft} / \mathrm{yr}$ in 1975-94. This difference represents, on average, an increase in the daily mean streamflow of about $100 \mathrm{ft}^{3} / \mathrm{s}$. The daily mean streamflow at station 07124000 increased in every month after 1974 (fig. 17); the differences in streamflow were significant for all 12 months (table 8). The increased streamflow probably is attributable to a combination of factors, including the WWSP and associated changes in growing-season and nongrowing-season irrigation practices and the increased importation of water from the western slope for irrigation. The effects of these factors are greatest at Las Animas because it is the farthest downstream station between Pueblo Reservoir and John Martin Reservoir. 


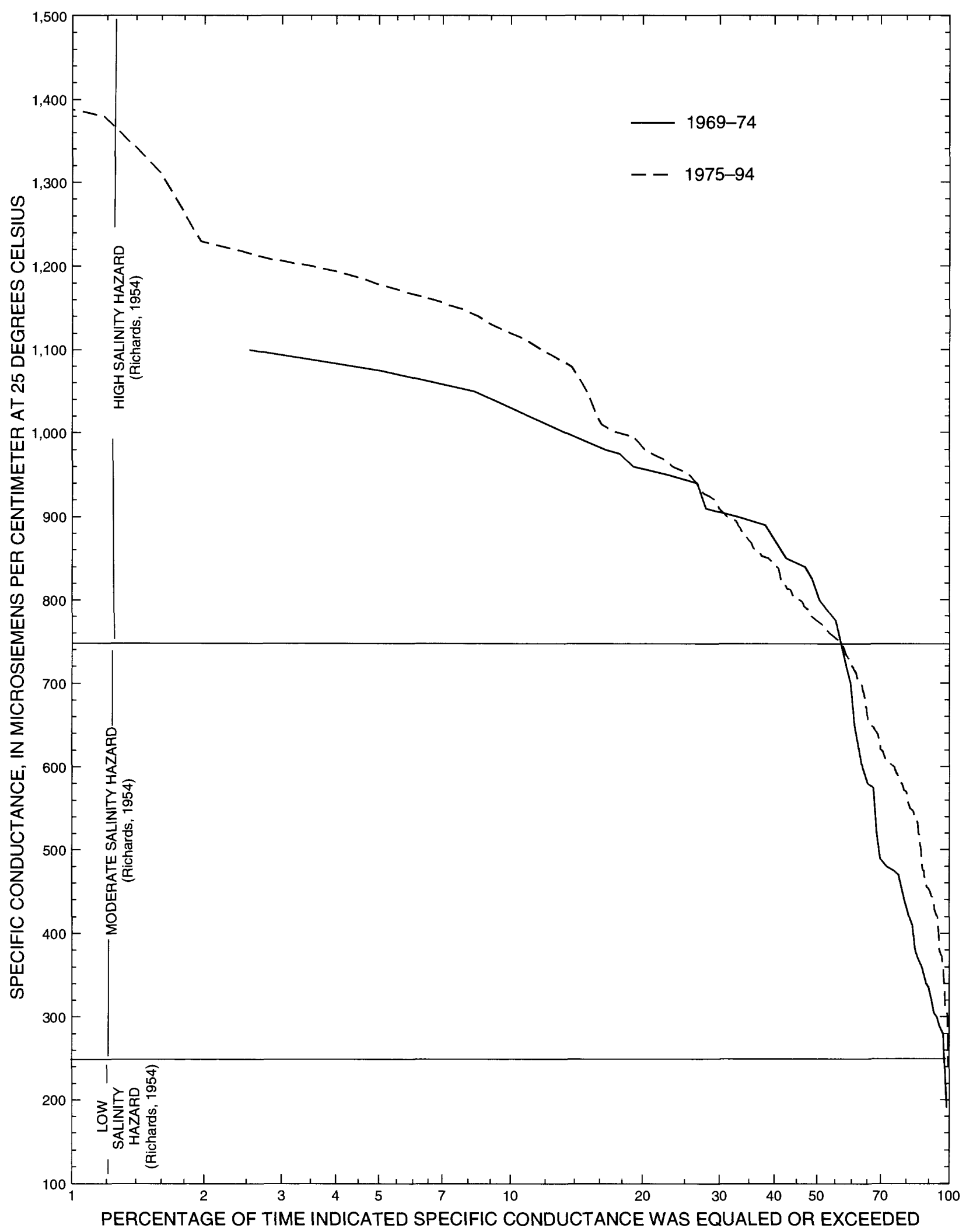

Figure 16. Duration frequency of specific conductance at station 07109500 (Arkansas River near Avondale), 1969-74 and $1975-94$. 


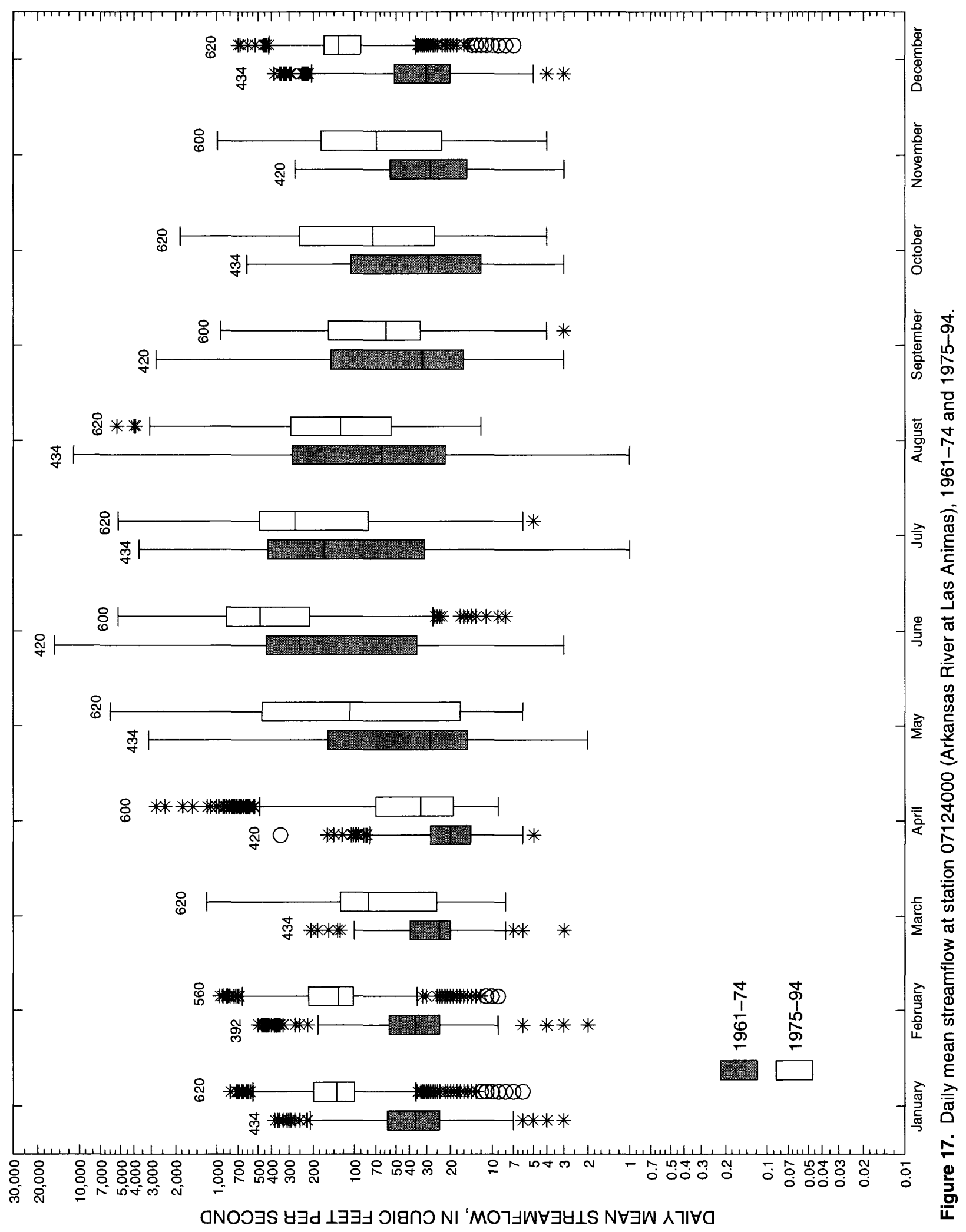


Table 8. Step-trend results on the daily mean streamflow at station 07124000 (Arkansas River at Las Animas) between 1961-74 and 1975-94

[ $\mathrm{ft}^{3} / \mathrm{s}$, cubic feet per second; $\mathrm{N}$, number of values; $\mathrm{p}$ value is the significance level of the test; <, less than; $\mathrm{I}$, statistically significant increasing trend]

\begin{tabular}{|c|c|c|c|c|c|c|}
\hline \multirow[b]{2}{*}{ Month } & \multicolumn{2}{|c|}{$1961-74$} & \multicolumn{2}{|c|}{ 1975-94 } & \multirow[b]{2}{*}{$p$ value } & \multirow[b]{2}{*}{ Significance $^{1}$} \\
\hline & $\begin{array}{c}\text { Median } \\
\text { streamflow } \\
\left(\mathrm{ft}^{3} / \mathrm{s}\right)\end{array}$ & $\mathbf{N}$ & $\begin{array}{c}\text { Median } \\
\text { streamflow } \\
\left(\mathrm{ft}^{3} / \mathrm{s}\right)\end{array}$ & $\mathbf{N}$ & & \\
\hline January & 36 & 434 & 135 & 620 & $<0.01$ & I \\
\hline February & 36 & 392 & 130 & 560 & $<.01$ & I \\
\hline March & 24 & 434 & 79 & 620 & $<.01$ & I \\
\hline April & 20 & 420 & 33 & 600 & $<.01$ & I \\
\hline May & 28 & 434 & 108 & 620 & $<.01$ & I \\
\hline June & 250 & 420 & 484 & 600 & $<.01$ & I \\
\hline July & 168 & 434 & 272 & 620 & $<.01$ & I \\
\hline August & 63 & 434 & 126 & 620 & $<.01$ & I \\
\hline September & 32 & 420 & 59 & 600 & $<.01$ & I \\
\hline October & 29 & 434 & 74 & 620 & $<.01$ & I \\
\hline November & 28 & 420 & 69 & 600 & $<.01$ & I \\
\hline December & 30 & 434 & 130 & 620 & $<.01$ & I \\
\hline
\end{tabular}

${ }^{1}$ A statistically significant trend was defined as having a $p$ value less than or equal to 0.05 .

Prior to the WWSP, many irrigators diverted winter streamflow and applied the water to barren fields in order to maintain soil moisture. Because of this practice and the already seasonally low streamflow, most winter streamflow was diverted and consumed upstream from Las Animas. After the WWSP began, winter streamflow was stored in Pueblo Reservoir, John Martin Reservoir, and in several small off-channel reservoirs. Releases of stored WWSP water to downstream irrigators generally were made at high rates during the irrigation season in order to minimize transit losses. Therefore, a larger percentage of winter water, which was released from reservoir storage, probably flows to downstream irrigation canals, thereby increasing the volume of applied water and the associated volume of irrigation-return flow to the river. Additionally, as part of the WWSP and the 1980 operating plan for John Martin Reservoir, three large irrigation-canal companies have been allowed to store winter water in John Martin Reservoir as an alternative to storage in Pueblo Reservoir or in private off-channel reservoirs. This water now flows by Las Animas, whereas prior to the WWSP, it may have been diverted and consumptively used. The Fort Lyon Canal, which diverts streamflow from the river about
30 mi upstream from Las Animas, receives a substantial percentage of the WWSP water and the imported Project water during the irrigation season. Because of its proximity to the Fort Lyon Canal, the Las Animas site probably benefits from increased irrigation-return flow to the river from land irrigated by the Fort Lyon Canal. On average, the Fort Lyon Canal received about 57,400 acre-ft/yr of WWSP water and about 10,400 acre-ft/yr of Project water since 1975 (Thomas C. Simpson, Southeastern Colorado Water Conservancy District, written commun., 1997).

The relation of annual streamflow at Avondale, where streamflow in the lower Arkansas River Basin is largest, to annual streamflow at four downstream sites (fig. 18) illustrates the effects of the WWSP and transmountain imports on streamflow. Doublemass curves (fig. 18) are plots of cumulative values of one variable compared to cumulative values of another variable. The theory of the double-mass curve is that a graph of the cumulation of one quantity compared to the cumulation of another quantity during the same time period will plot as a straight line as long as the data are proportional; the slope of the line will represent the constant of proportionality between the quantities (Searcy and Hardman, 1960). 

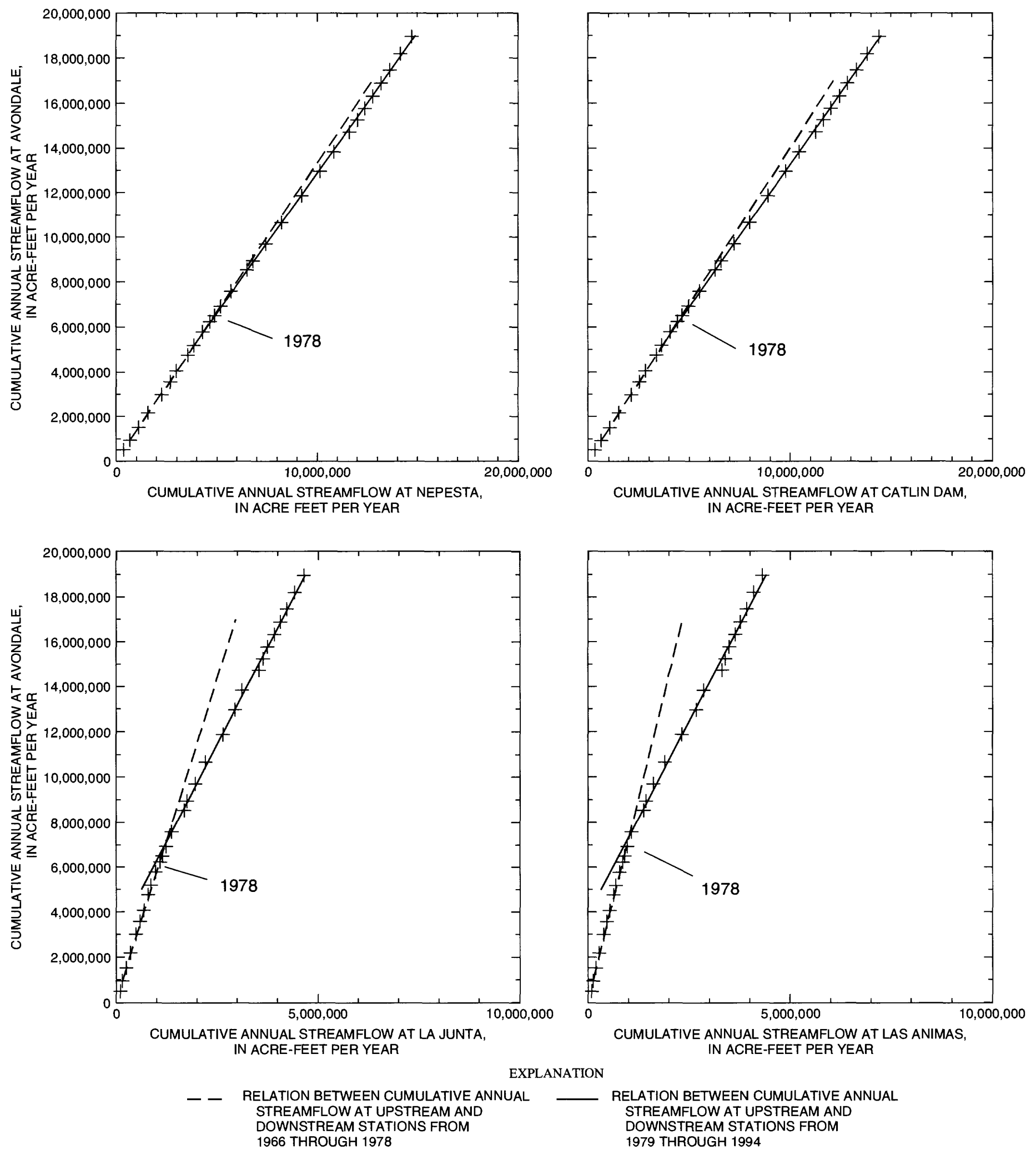

Figure 18. Relation of cumulative annual streamflow at station 07109500 (Arkansas River near Avondale) to cumulative annual streamflow at four downstream sites, 1966-94. 
A break in the slope of the double-mass curve means that a change has occurred in the constant of proportionality. The double-mass curves in this analysis (fig. 18) indicate that the accumulative rate of streamflow past the gaging stations downstream from Avondale changed substantially after 1978 and that the degree of change increased downstream. A larger percentage of annual streamflow at Avondale flowed past downstream sites after 1978 than before. The change probably occurred after 1978 because the WWSP only had operated for 2 years prior to 1977 , when its operation was curtailed for 1 year until 1978. The effects of transmountain imports also probably had some effect on the change in the constants of proportionality that occurred in 1979. On average from 1966-78, the percentage of annual streamflow that flowed from Avondale past Nepesta, Catlin Dam, La Junta, and Las Animas was 75 percent, 72 percent, 18 percent, and 14 percent, respectively. From 1979-94, the percentage of annual streamflow that flowed from Avondale past Nepesta, Catlin Dam, La Junta, and Las Animas was 78 percent, 78 percent, 27 percent, and 26 percent, respectively.

Although the range in specific-conductance values at station 07124000 changed little after 1974 (fig. 19), the median specific conductance decreased significantly $(\mathrm{p}<0.01)$ from $3,000 \mu \mathrm{S} / \mathrm{cm}$ in $1961-74$ to $2,500 \mu \mathrm{S} / \mathrm{cm}$ in $1975-94$. Specific-conductance values were smaller in all months during 1975-94 (fig. 20), but the only statistically significant differences in specific conductance occurred in March, April, and June (table 9), despite the significant increases in streamflow during each month (table 8).

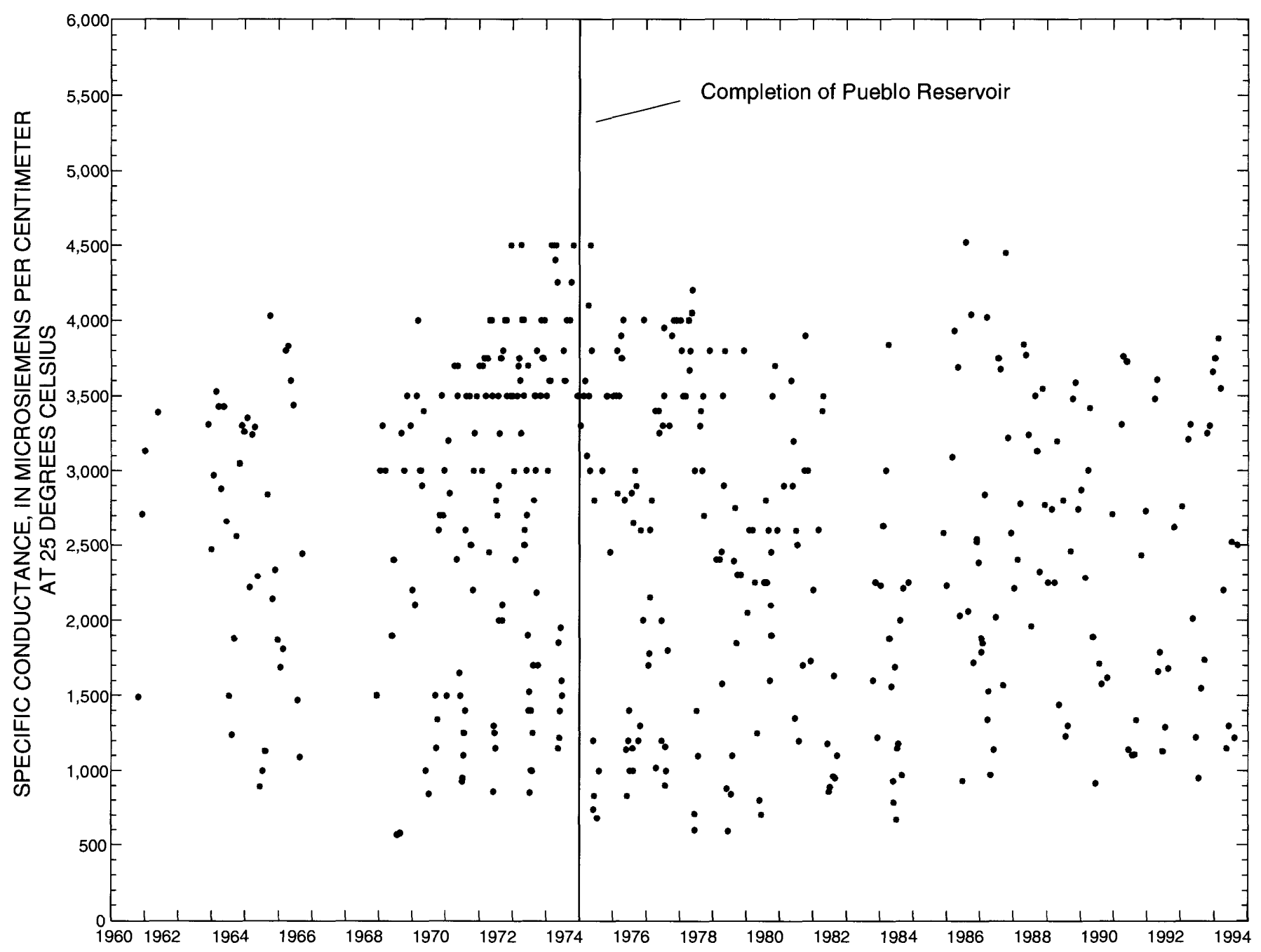

Figure 19. Specific conductance at station 07124000 (Arkansas River at Las Animas), 1961-94. 


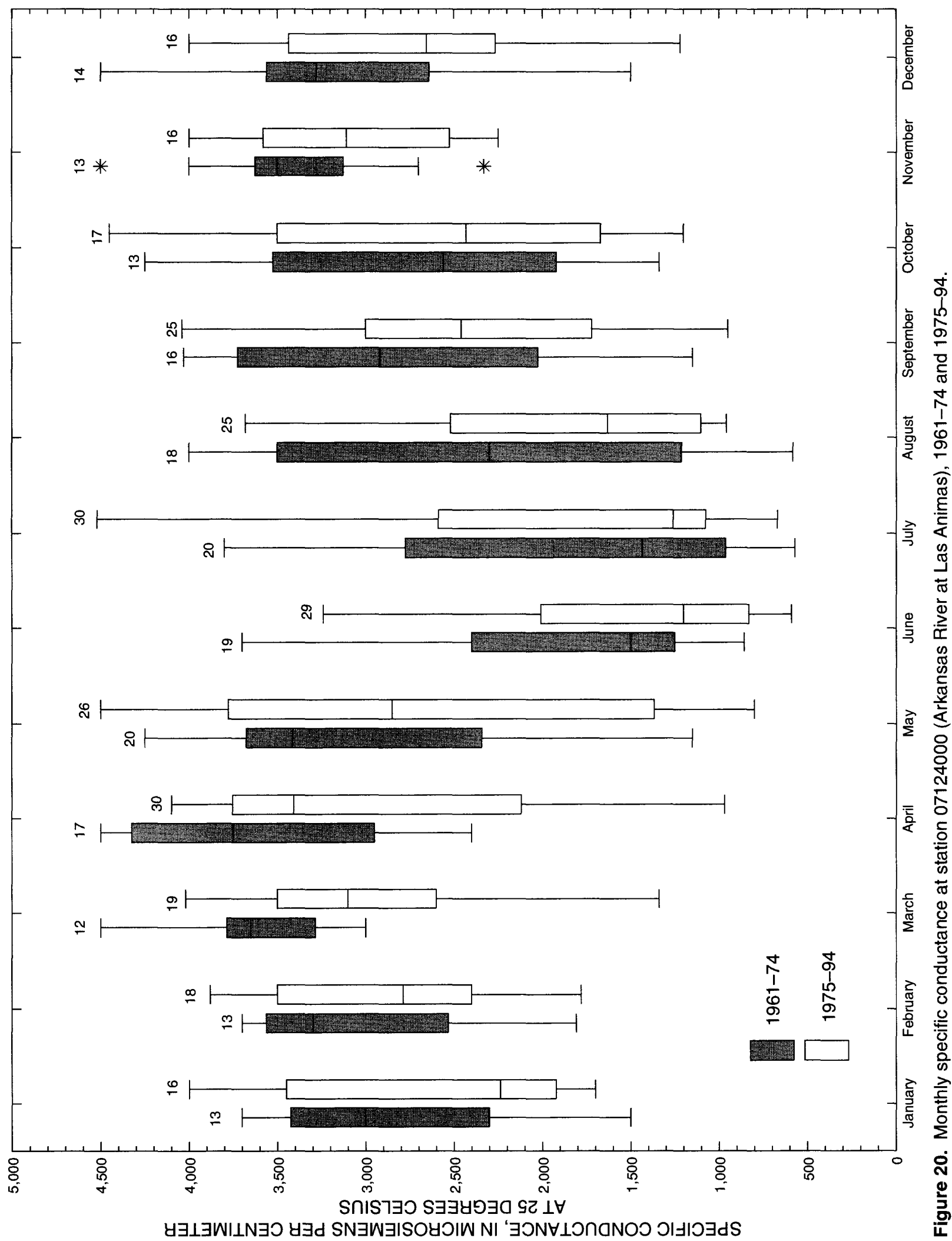


On a seasonal basis, the median specific conductance during the growing season decreased significantly ( $\mathrm{p} \leq 0.01$ ) from $2,820 \mu \mathrm{S} / \mathrm{cm}$ in $1961-74$ to $2,250 \mu \mathrm{S} / \mathrm{cm}$ in $1975-94$. Similarly, during the winterstorage season, the median specific conductance in the growing season decreased significantly $(\mathrm{p}=0.02)$ from $3,300 \mu \mathrm{S} / \mathrm{cm}$ in $1961-74$ to $2,730 \mu \mathrm{S} / \mathrm{cm}$ in $1975-94$. The decrease in specific conductance at Las Animas did not change the salinity-hazard classification of the water. The water retained the same C3 (high salinity hazard) to C4 (very high salinity hazard) classifications that were common to the period prior to the construction of Pueblo Reservoir (Richards, 1954).

\section{Below John Martin Reservoir}

Station 07130500 (Arkansas River below John Martin Reservoir) is located 0.2 mi downstream from John Martin Reservoir (fig. 1). A substantial change in reservoir operations occurred with the adoption of the 1980 operating plan, as discussed in the "John Martin Reservoir" section; therefore, streamflow and specific-conductance trends were evaluated for changes that might have occurred after 1979. Water quality at station 07130500 is important from an irrigated-agriculture perspective, but water quality also is important from a domestic water-supply perspective because the city of Lamar diverts water from the river to provide artificial recharge to the alluvial aquifer in the vicinity of its municipal well field. Streamflow and specific-conductance data were available at station 07130500 for 1955-94.

The median annual streamflow at station 07130500 increased significantly $(\mathrm{p}<0.01)$ from about 142,000 acre-ft/yr during 1955-79 to about 231,400 acre-ft/yr during 1980-94. The median annual streamflow that entered the lower basin from the upper basin, as indicated by the record at station 07096000 , increased an insignificant amount $(\mathrm{p}=0.20)$ from 481,000 acre-ft/yr in $1955-79$ to about 574,400 acre-ft/yr in 1980-94. The increased median annual streamflow at station 07130500 probably is attributable to the combined effects of the 1980 reservoir operating plan, the decreased diversion and consumptive use of winter streamflow upstream from the reservoir, increased irrigation-return flows resulting from irrigation with WWSP and Project water, and the storage of winter water in John Martin Reservoir by three canal companies. The effect of these factors is evidenced by a large increase

Table 9. Step-trend results on specific conductance at station 07124000 (Arkansas River at Las Animas) between 1961-74 and 1975-94

$[\mu \mathrm{S} / \mathrm{cm}$, microsiemens per centimeter at 25 degrees Celsius; $\mathrm{N}$, number of values; $\mathrm{p}$ value is the significance level of the test; NS, trend not statistically significant; D, statistically significant decreasing trend]

\begin{tabular}{|c|c|c|c|c|c|c|}
\hline \multirow[b]{2}{*}{ Month } & \multicolumn{2}{|c|}{$1961-74$} & \multicolumn{2}{|c|}{$1975-94$} & \multirow[b]{2}{*}{ p value } & \multirow[b]{2}{*}{ Significance } \\
\hline & $\begin{array}{c}\text { Median } \\
\text { specific } \\
\text { conductance } \\
(\mu \mathrm{S} / \mathrm{cm})\end{array}$ & $\mathbf{N}$ & $\begin{array}{c}\text { Median } \\
\text { specific } \\
\text { conductance } \\
(\mu \mathrm{S} / \mathrm{cm})\end{array}$ & $\mathbf{N}$ & & \\
\hline January & 3,000 & 13 & 2,240 & 16 & 0.51 & NS \\
\hline February & 3,300 & 13 & 2,790 & 18 & .26 & NS \\
\hline May & 3,420 & 20 & 2,850 & 26 & .26 & NS \\
\hline June & 1,500 & 19 & 1,200 & 29 & .05 & $\mathrm{D}$ \\
\hline July & 1,440 & 20 & 1,260 & 30 & .95 & NS \\
\hline August & 2,300 & 18 & 1,630 & 25 & .22 & NS \\
\hline September & 2,920 & 16 & 2,460 & 25 & .18 & NS \\
\hline
\end{tabular}

${ }^{1}$ A statistically significant trend was defined as having a p value less than or equal to 0.05 . 
in the total annual streamflow in the Arkansas River about 3 mi upstream from John Martin Reservoir at station 07124000 . The median annual streamflow at station 07124000 increased 142 percent from $76,400 \mathrm{acre}-\mathrm{ft} / \mathrm{yr}$ in $1955-79$ to $185,200 \mathrm{acre}-\mathrm{ft} / \mathrm{yr}$ in 1980-94. Additionally, as discussed in the "John Martin Reservoir" section, 35 percent of the winter water stored in the reservoir by three canal companies was shifted to Arkansas River Compact use and was subject to downstream release. Prior to 1980 , after the winter-storage period, reservoir storage usually was drawn down to empty or almost empty very early in the irrigation season, often by the middle of April (fig. 21). From 1955 through 1979, reservoir storage.was completely depleted by April 30 in 15 of the 25 years. Reservoir storage increased substantially in all months after 1979 (fig. 21).

Daily mean streamflow at station 07130500 tended to increase during April-October after 1979, whereas daily mean streamflow in November through
March tended to decrease or remain constant (fig. 22). All increases in daily mean streamflow, except for April, were statistically significant (table 10). The increase in streamflow during the growing season was a function of the increased availability of water in the reservoir and in the changes in reservoir-operating practices. Reservoir storage that was previously released in the spring was released throughout the summer. Although streamflow tended to decrease significantly during winter, the winter streamflow generally was so small that the decreases were relatively inconsequential (table 10).

Specific conductance at station 07130500 changed markedly after the implementation of the John Martin Reservoir 1980 operating plan (fig. 23). The median specific conductance decreased significantly ( $<<0.01$ ) from $2,700 \mu \mathrm{S} / \mathrm{cm}$ in $1955-79$ to $2,260 \mu \mathrm{S} / \mathrm{cm}$ in $1980-94$. The most obvious change in specific conductance was a narrowing of the range in values after 1979.

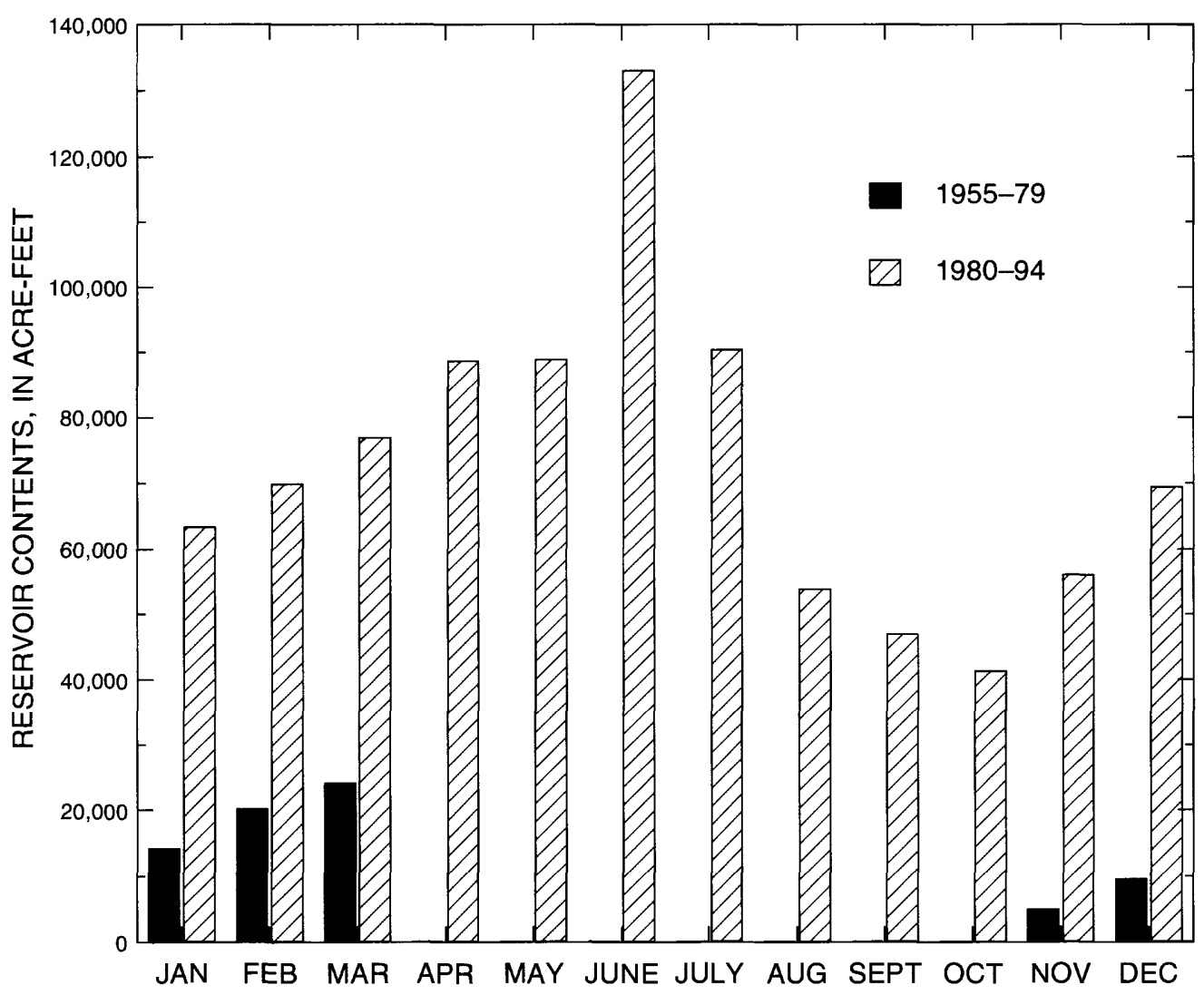

Figure 21. Median end-of-month contents of John Martin Reservoir, 1955-79 and 1980-94. 


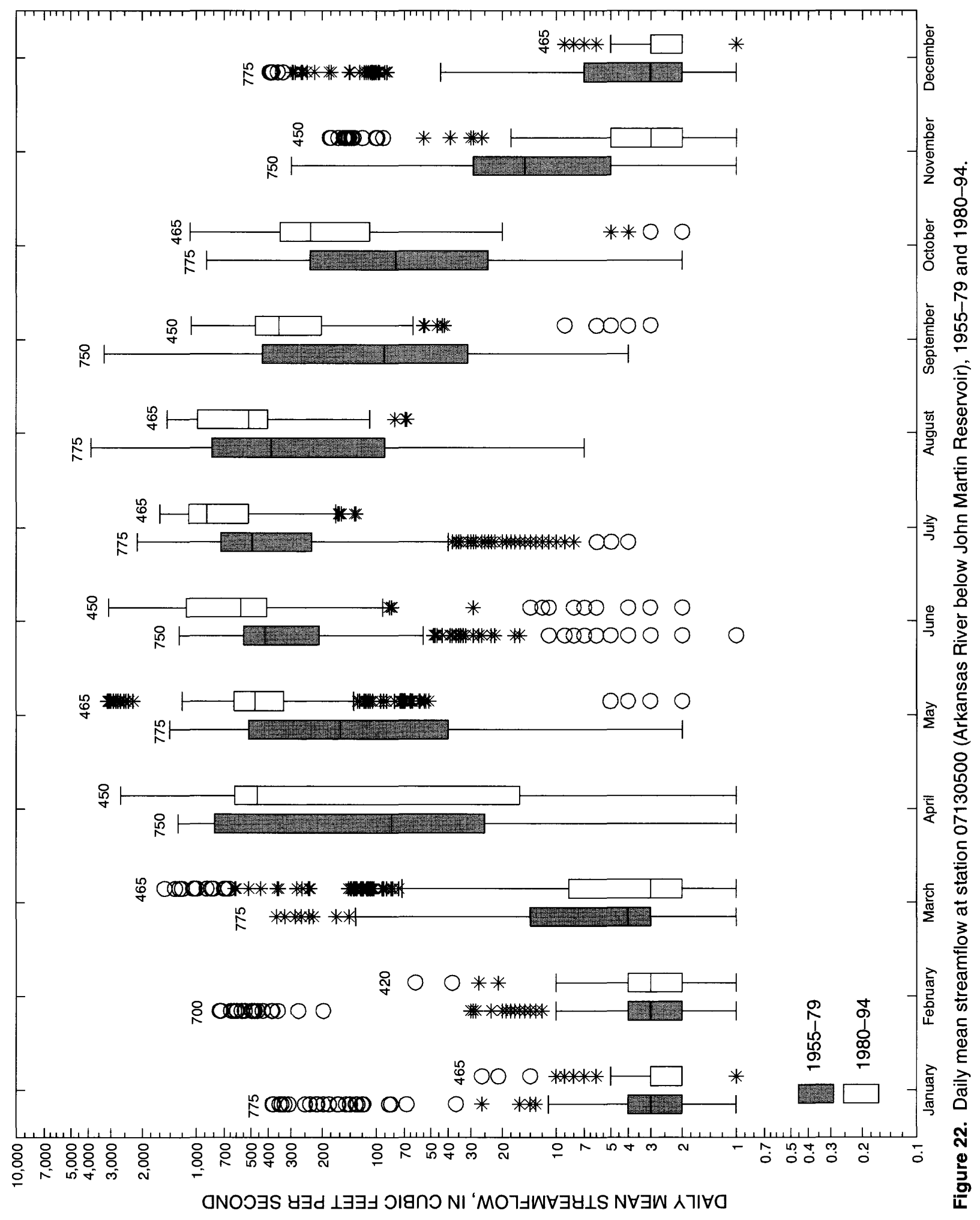


Table 10. Step-trend results on the daily mean streamflow at station 07130500 (Arkansas River below John Martin Reservoir) between 1955-79 and 1980-94

[ $\mathrm{ft}^{3} / \mathrm{s}$, cubic feet per second; $\mathrm{N}$, number of values; $\mathrm{p}$ value is the significance level of the test; < less than; NS, trend not statistically significant; I, statistically significant increasing trend; D, statistically significant decreasing trend]

\begin{tabular}{|c|c|c|c|c|c|c|}
\hline \multirow[b]{2}{*}{ Month } & \multicolumn{2}{|c|}{$1955-79$} & \multicolumn{2}{|c|}{$1980-94$} & \multirow[b]{2}{*}{$p$ value } & \multirow[b]{2}{*}{ Significance $^{1}$} \\
\hline & $\begin{array}{c}\text { Median } \\
\text { streamflow } \\
\left(\mathrm{ft}^{3} / \mathrm{s}\right)\end{array}$ & $N$ & $\begin{array}{c}\text { Median } \\
\text { streamflow } \\
\left(\mathrm{ft}^{3} / \mathrm{s}\right)\end{array}$ & $\mathbf{N}$ & & \\
\hline January & 3 & 775 & 2 & 465 & $<0.01$ & $\mathrm{D}$ \\
\hline February & 3 & 700 & 3 & 420 & $<.01$ & $\mathrm{D}$ \\
\hline March & 4 & 775 & 3 & 465 & $<.01$ & D \\
\hline April & 82 & 750 & 460 & 450 & .61 & NS \\
\hline May & 159 & 775 & 470 & 465 & $<.01$ & I \\
\hline June & 415 & 750 & 566 & 450 & $<.01$ & I \\
\hline July & 490 & 775 & 878 & 465 & $<.01$ & I \\
\hline August & 385 & 775 & 514 & 465 & $<.01$ & I \\
\hline September & 90 & 750 & 348 & 450 & $<.01$ & I \\
\hline October & 78 & 775 & 232 & 465 & $<.01$ & I \\
\hline November & 15 & 750 & 3 & 450 & $<.01$ & D \\
\hline December & 3 & 775 & 2 & 465 & $<.01$ & D \\
\hline
\end{tabular}

${ }^{1}$ A statistically significant trend was defined as having a p value less than or equal to 0.05 .

This change is very similar to the change in specific conductance that occurred at station 07099400 after the construction of Pueblo Reservoir (fig. 10). The annual maximum specific conductance at station 07130500 decreased from a range of about 4,500 to $5,000 \mu \mathrm{S} / \mathrm{cm}$ in $1955-79$ to a range of about 2,500 to $3,800 \mu \mathrm{S} / \mathrm{cm}$ in 1980-94 (fig. 23). The annual minimum specific conductance increased from a range of about 500 to $1,000 \mu \mathrm{S} / \mathrm{cm}$ in $1955-79$ to a range of about 1,000 to $1,500 \mu \mathrm{S} / \mathrm{cm}$ in $1980-94$ (fig. 23). Specific conductance generally decreased after 1979 in all months, except June (fig. 24); however, the only statistically significant decreases were in SeptemberApril (table 11). Seasonally, the median specific conductance during the growing season decreased significantly $(\mathrm{p}=0.02)$ from $2,180 \mu \mathrm{S} / \mathrm{cm}$ in $1955-79$ to $2,050 \mu \mathrm{S} / \mathrm{cm}$ in $1980-94$. Similarly, the median specific conductance in the winterstorage season decreased significantly $(\mathrm{p} \leq 0.01)$ from $3,650 \mu \mathrm{S} / \mathrm{cm}$ in $1955-79$ to $2,640 \mu \mathrm{S} / \mathrm{cm}$ in 1980-94.

The changes in specific conductance that occurred at station 07130500 since 1979 probably were caused by: (1) Decreased specific conductance in the reservoir inflow, as indicated by the specific-conductance trends at station 07124000 ; (2) the establishment of long-term storage and a permanent pool in John Martin Reservoir; and (3) an increase in the mixing of water with different specific-conductance values in the reservoir. The establishment of the 10,000-acre-ft permanent pool and the implementation of the 1980 operating plan eliminated the complete drawdown of reservoir storage, which frequently occurred prior to 1980 . The increase in storage resulted in an increase in the mixing of low- and high-specific-conductance water in the reservoir and narrowed the range of specific conductance in the reservoir outflow. The net result of these conditions was increased specific conductance during times when specific conductance historically was lowest and decreased specific conductance during times when specific conductance historically was highest. The 1980 operating plan and the 10,000-acre-ft permanent pool might have changed the timing and magnitude of the annual minimum specific conductance at station 07130500 . The annual minimum specific conductance, prior to 1980 , 
generally occurred in June or July and was associated with snowmelt runoff from the upper basin. Prior to 1980 , reservoir storage generally was depleted by the time of snowmelt runoff, and the low-specificconductance water did not mix with the elevated specific-conductance water in the reservoir. After 1980 and with a permanent pool in the reservoir, the low-specific-conductance runoff mixed with the contents of the reservoir, thereby causing the annual minimum specific conductance to occur later in the summer.

The city of Lamar typically has diverted about 2,000 acre-ft/yr from the river to provide additional recharge to the alluvial aquifer where its municipal well field is located. Water generally has been diverted during June in order to obtain the lowest specific-conductance water. Dannie McMillan (city of Lamar, oral commun., 1996) reported that the dissolved-solids concentration in the municipal water supply for Lamar has increased since 1980, although there are no data to quantify the change. The change in the timing of the minimum specific conductance at station 07130500 may have affected the quality of ground water that the city of Lamar uses as its municipal water supply.

The changes in specific conductance that occurred at station 07130500 did not change the salinity-hazard classification of the water for irrigated agriculture. Water at station 07130500 was classified as Class C3 (high salinity hazard) and Class C4 (very high salinity hazard) before and after 1980.

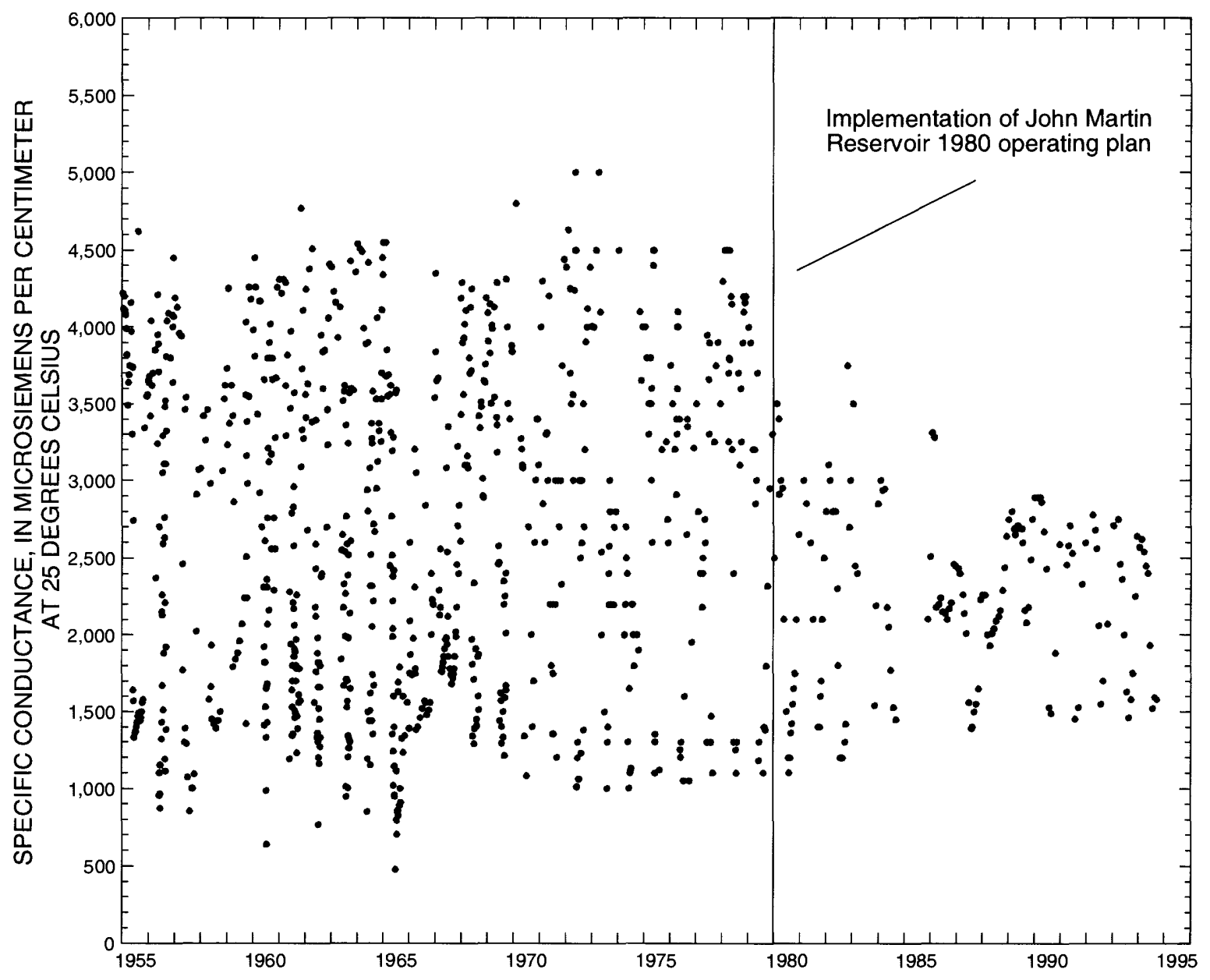

Figure 23. Specific conductance at station 07130500 (Arkansas River below John Martin Reservoir), 1955-94. 


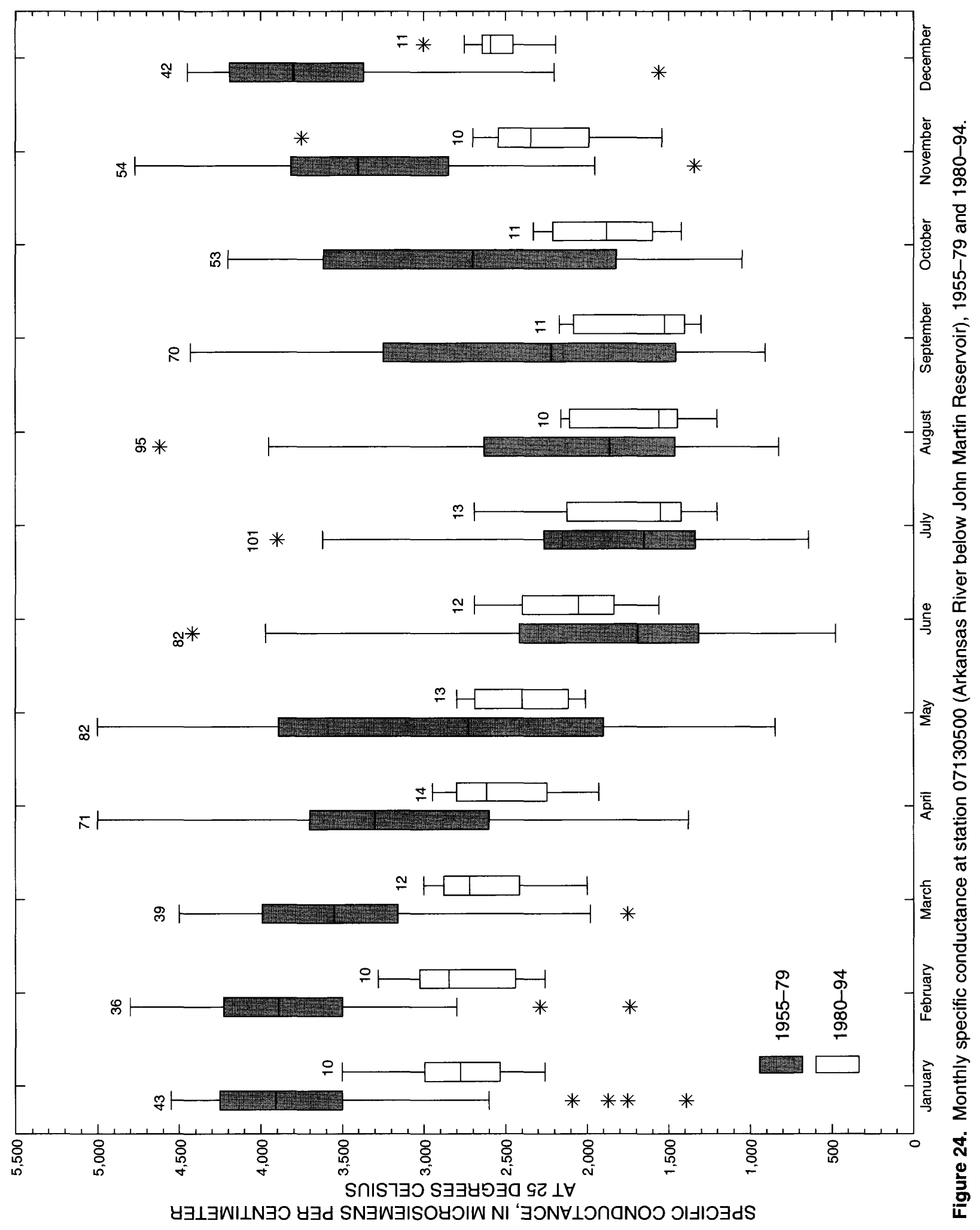


Table 11. Step-trend results on specific conductance at station 07130500 (Arkansas River below John Martin Reservoir) between 1955-79 and 1980-94

$[\mu \mathrm{S} / \mathrm{cm}$, microsiemens per centimeter at 25 degrees Celsius; $\mathrm{N}$, number of values; $\mathrm{p}$ value is the significance level of the test; <, less than; NS, trend not statistically significant; $\mathrm{D}$, statistically significant decreasing trend]

\begin{tabular}{|c|c|c|c|c|c|c|}
\hline \multirow[b]{2}{*}{ Month } & \multicolumn{2}{|c|}{ 1955-79 } & \multicolumn{2}{|c|}{ 1980-94 } & \multirow[b]{2}{*}{$p$ value } & \multirow[b]{2}{*}{ Significance $^{1}$} \\
\hline & $\begin{array}{c}\text { Median } \\
\text { specific } \\
\text { conductance } \\
(\mu \mathrm{S} / \mathrm{cm})\end{array}$ & $\mathbf{N}$ & $\begin{array}{c}\text { Median } \\
\text { specific } \\
\text { conductance } \\
(\mu \mathrm{S} / \mathrm{cm})\end{array}$ & $\mathbf{N}$ & & \\
\hline January & 3,910 & 43 & 2,780 & 10 & $<0.01$ & $\bar{D}$ \\
\hline February & 3,890 & 36 & 2,840 & 10 & $<.01$ & D \\
\hline March & 3,550 & 39 & 2,720 & 12 & $<.01$ & D \\
\hline April & 3,300 & 71 & 2,620 & 14 & $<.01$ & D \\
\hline May & 2,720 & 82 & 2,400 & 13 & .30 & NS \\
\hline June & 1,690 & 82 & 2,050 & 12 & .10 & NS \\
\hline July & 1,650 & 101 & 1,550 & 13 & .94 & NS \\
\hline August & 1,860 & 95 & 1,560 & 10 & .21 & NS \\
\hline September & 2,220 & 70 & 1,530 & 11 & .04 & D \\
\hline October & 2,700 & 53 & 1,880 & 11 & .02 & D \\
\hline November & 3,400 & 54 & 2,340 & 10 & $<.01$ & D \\
\hline December & 3,800 & 42 & 2,590 & 11 & $<.01$ & D \\
\hline
\end{tabular}

${ }^{1}$ A statistically significant trend was defined as having a $\mathrm{p}$ value less than or equal to 0.05 .

\section{At Lamar}

Station 07133000 (Arkansas River at Lamar) is located about $20 \mathrm{mi}$ downstream from John Martin Reservoir. Water quality at station 07133000 is important from an agricultural perspective because several large irrigation canals divert water from the Arkansas River in the reach between station 07133000 and the Colorado-Kansas State line. Streamflow and specific-conductance data were available at station 07133000 for 1964-94.

The median annual streamflow at station 07133000 increased significantly $(\mathrm{p}<0.01)$ from about $39,100 \mathrm{acre}-\mathrm{ft} / \mathrm{yr}$ in $1964-79$ to about $67,100 \mathrm{acre}-\mathrm{ft} / \mathrm{yr}$ in 1980-94. The daily mean streamflow at station 07133000 generally increased in all months after 1979, except April (fig. 25). Although 11 of the 12 increases were significant at a 95 -percent confidence level, the magnitude of the increases generally was small (table 12). The increased streamflow was largely attributable to increased inflow to John Martin Reservoir, as discussed in the "At Las Animas" and "Below John Martin Reservoir" sections.
The large increase in the median daily streamflow in July (52-411 $\mathrm{ft}^{3} / \mathrm{s}$ ) (table 12) is a function of the John Martin Reservoir 1980 operating plan and the release of stored water for downstream delivery to irrigators in Kansas. Prior to the 1980 operating plan, Colorado and Kansas irrigators downstream from John Martin Reservoir generally received their shares of water very early in the irrigation season. After the 1980 operating plan was implemented, Kansas irrigators could delay the delivery of their water until later in the irrigation season.

Specific conductance at station 07133000 (fig. 26), like specific conductance at station 07130500 (fig. 23), changed substantially after 1979. The median specific conductance at station 07133000 decreased about 12 percent from $4,000 \mu \mathrm{S} / \mathrm{cm}$ in $1964-79$ to $3,510 \mu \mathrm{S} / \mathrm{cm}$ in $1980-94$. The annual maximum specific conductance decreased from a range of about 5,500 to $8,000 \mu \mathrm{S} / \mathrm{cm}$ in $1964-79$ to a range of about 4,500 to $5,000 \mu \mathrm{S} / \mathrm{cm}$ in $1980-94$ (fig. 26). The annual minimum specific conductance increased from a range of about 500 to $1,500 \mu \mathrm{S} / \mathrm{cm}$ 


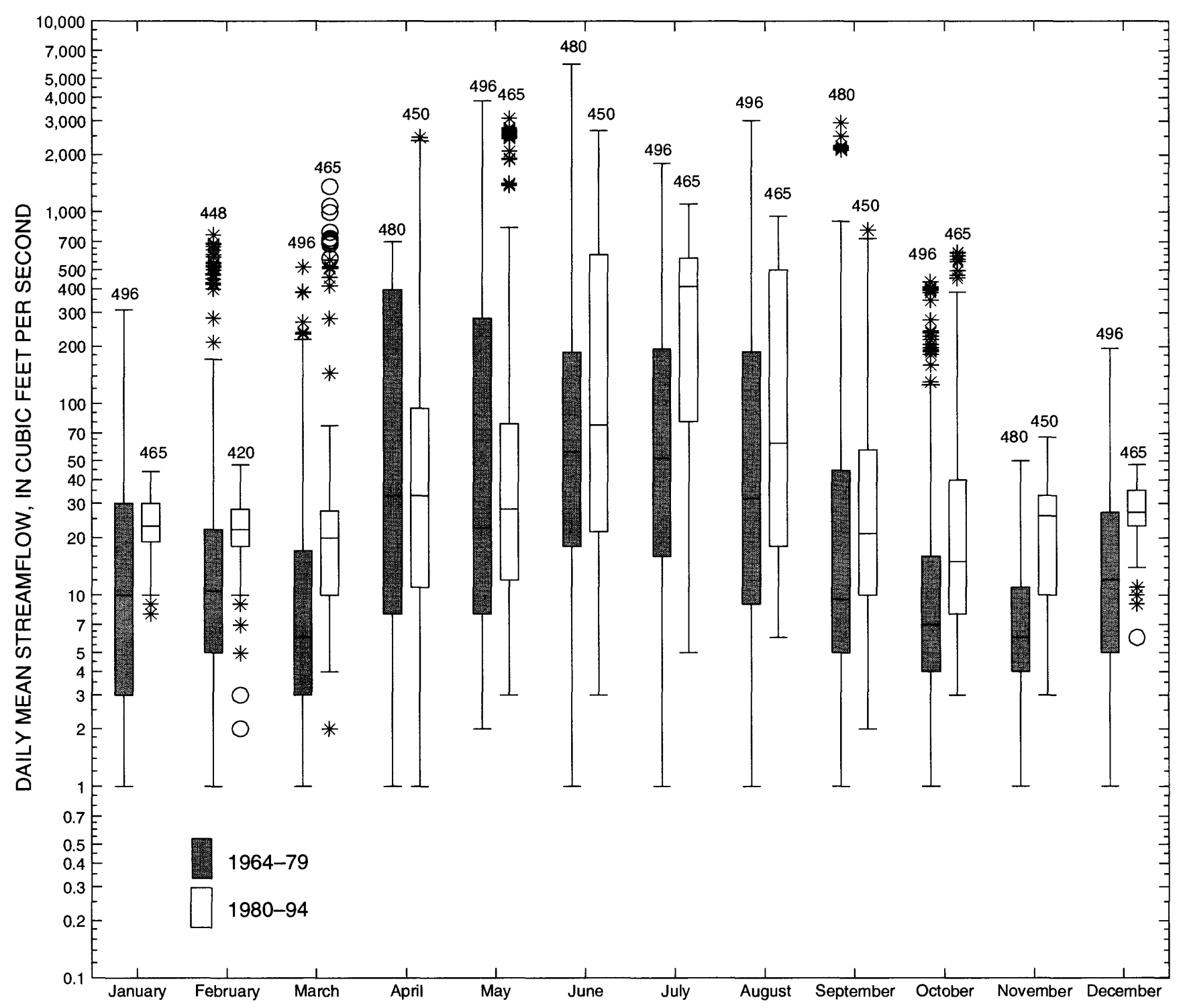

Figure 25. Daily mean streamflow at station 07133000 (Arkansas River at Lamar), 1964-79 and 1980-94.

in $1964-79$ to a range of about 700 to $2,000 \mu \mathrm{S} / \mathrm{cm}$ in 1980-94 (fig. 26). Specific conductance generally decreased or remained relatively constant after 1979 in all months, except for June (fig. 27). The decreases in specific conductance were statistically significant for February through April and September through December (table 13). Seasonally, the median specific conductance in the growing season decreased significantly ( $\mathrm{p}=0.01$ ) from $3,400 \mu \mathrm{S} / \mathrm{cm}$ in $1964-79$ to $2,995 \mu \mathrm{S} / \mathrm{cm}$ in $1980-94$. Similarly, the median specific conductance in the winter-storage season decreased significantly $(\mathrm{p} \leq 0.01)$ from $4,900 \mu \mathrm{S} / \mathrm{cm}$ in $1964-79$ to $4,375 \mu \mathrm{S} / \mathrm{cm}$ in $1980-94$. The variations and trends in specific conductance at station 07133000 were very similar to the variations and trends at station 07130500 and were attributable to decreased specific conductance in the inflow to John Martin Reservoir, the establishment of long-term storage and a permanent pool in John Martin Reservoir, and the mixing of low- and high-specific-conductance water in the reservoir. The changes in specific conductance that occurred at station 07133000 did not change the salinity-hazard classification of the water for irrigated agriculture. Water at station 07133000 was classified as Class C3 (high salinity hazard) and Class C4 (very high salinity hazard). 
Table 12. Step-trend results on the daily mean streamflow at station 07133000 (Arkansas River at Lamar) between 1964-79 and 1980-94

[ $\mathrm{ft}^{3} / \mathrm{s}$, cubic feet per second; $\mathrm{N}$, number of observations; $\mathrm{p}$ value is the significance level of the test; <, less than; NS, trend not statistically significant; I, statistically significant increasing trend]

\begin{tabular}{|c|c|c|c|c|c|c|}
\hline \multirow[b]{2}{*}{ Month } & \multicolumn{2}{|c|}{$1964-79$} & \multicolumn{2}{|c|}{$1980-94$} & \multirow[b]{2}{*}{$p$ value } & \multirow[b]{2}{*}{ Significance $^{1}$} \\
\hline & $\begin{array}{c}\text { Median } \\
\text { streamflow } \\
\left(\mathrm{ft}^{3} / \mathrm{s}\right)\end{array}$ & $\mathbf{N}$ & $\begin{array}{c}\text { Median } \\
\text { streamflow } \\
\left(\mathrm{ft}^{3} / \mathrm{s}\right)\end{array}$ & $\mathbf{N}$ & & \\
\hline January & 10 & 496 & 23 & 465 & $<0.01$ & I \\
\hline February & 10 & 448 & 22 & 420 & $<.01$ & I \\
\hline March & 6 & 496 & 20 & 465 & $<.01$ & I \\
\hline May & 22 & 496 & 28 & 465 & .04 & I \\
\hline June & 56 & 480 & 78 & 450 & $<.01$ & I \\
\hline July & 52 & 496 & 411 & 465 & $<.01$ & I \\
\hline August & 32 & 496 & 62 & 465 & $<.01$ & I \\
\hline September & 10 & 480 & 21 & 450 & $<.01$ & I \\
\hline
\end{tabular}

${ }^{1} \mathrm{~A}$ statistically significant trend was defined as having a $\mathrm{p}$ value less than or equal to 0.05 .

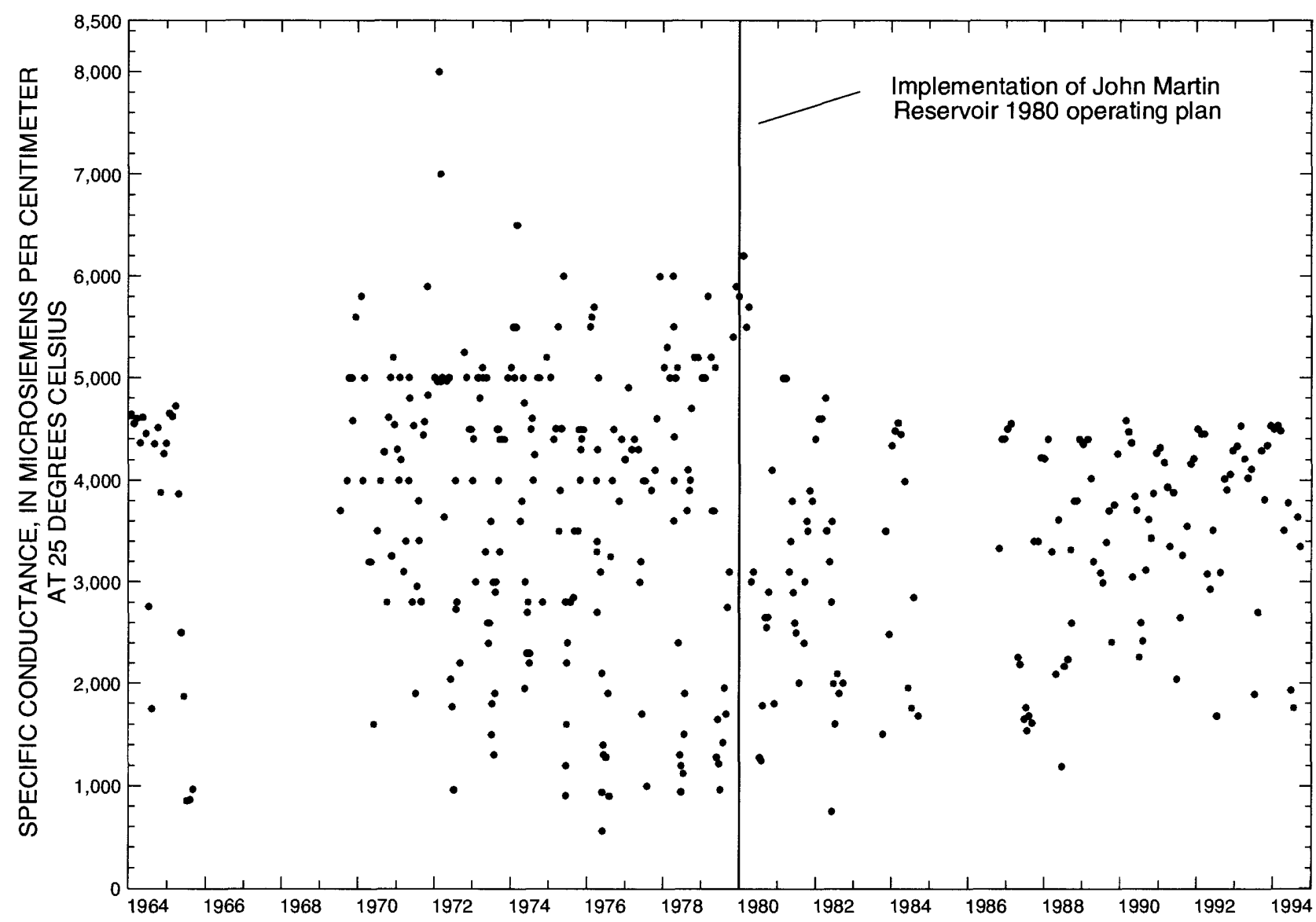

Figure 26. Specific conductance at station 07133000 (Arkansas River at Lamar), 1964-94. 


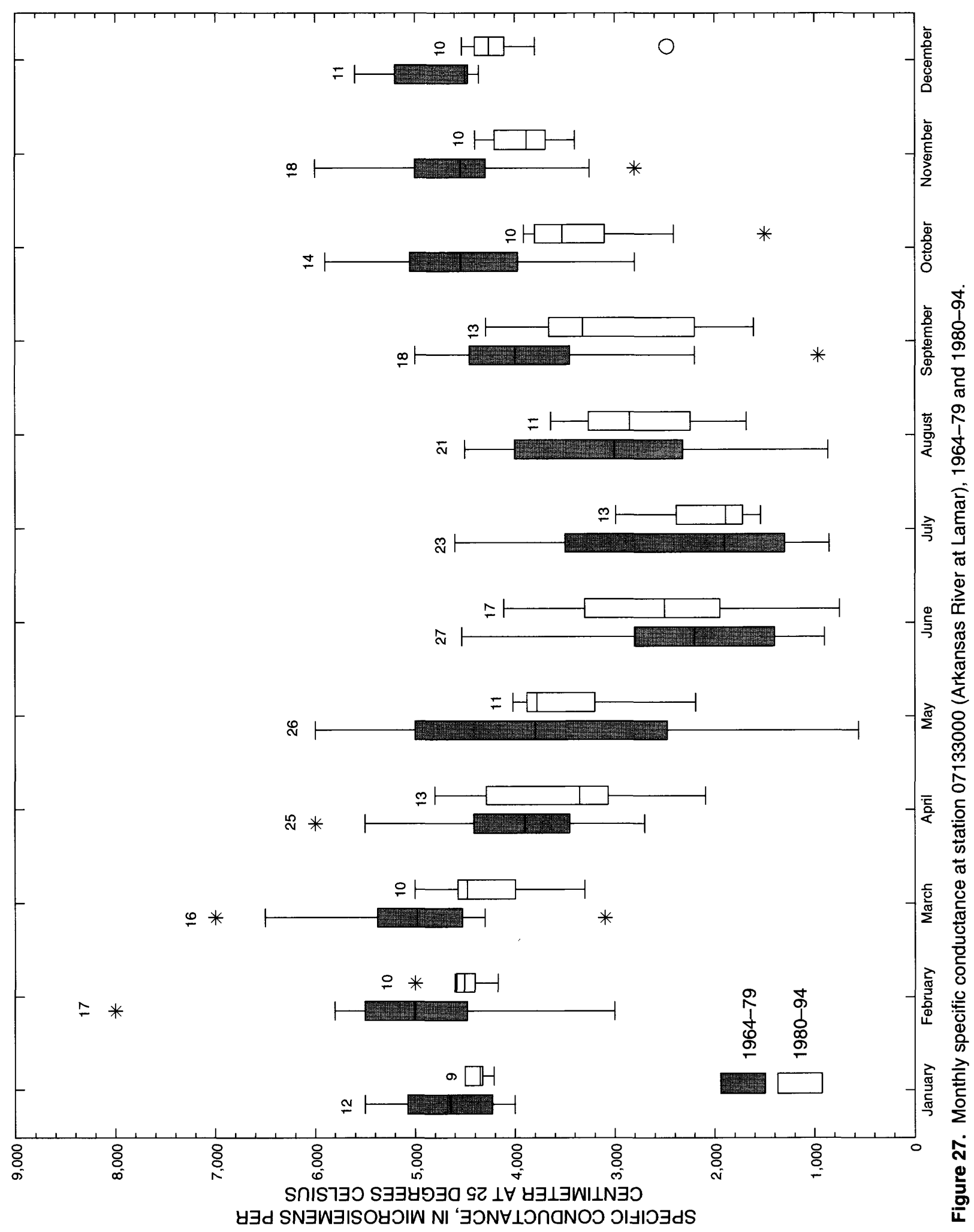


Table 13. Step-trend results on specific conductance at station 07133000 (Arkansas River at Lamar) between 1964-79 and 1980-94

$[\mu \mathrm{S} / \mathrm{cm}$, microsiemens per centimeter at 25 degrees Celsius; $\mathrm{N}$, number of values; $\mathrm{p}$ value is the significance level of the test; $<$, less than; NS, trend not statistically significant; D, statistically significant decreasing trend]

\begin{tabular}{|c|c|c|c|c|c|c|}
\hline \multirow[b]{2}{*}{ Month } & \multicolumn{2}{|c|}{ 1964-79 } & \multicolumn{2}{|c|}{ 1980-94 } & \multirow[b]{2}{*}{$p$ value } & \multirow[b]{2}{*}{ Significance ${ }^{1}$} \\
\hline & $\begin{array}{c}\text { Median } \\
\text { specific } \\
\text { conductance } \\
(\mu \mathrm{S} / \mathrm{cm})\end{array}$ & $\mathbf{N}$ & $\begin{array}{c}\text { Median } \\
\text { specific } \\
\text { conductance } \\
(\mu \mathrm{S} / \mathrm{cm})\end{array}$ & $\mathbf{N}$ & & \\
\hline January & 4,640 & 12 & 4,350 & 9 & 0.28 & NS \\
\hline February & 5,000 & 17 & 4,500 & 10 & .05 & D \\
\hline March & 4,980 & 16 & 4,480 & 10 & .01 & D \\
\hline April & 3,900 & 25 & 3,350 & 13 & .04 & D \\
\hline May & 3,800 & 26 & 3,780 & 11 & .62 & NS \\
\hline June & 2,200 & 27 & 2,500 & 17 & .35 & NS \\
\hline July & 1,900 & 23 & 1,890 & 13 & .69 & NS \\
\hline August & 3,000 & 21 & 2,850 & 11 & .32 & NS \\
\hline September & 4,000 & 18 & 3,320 & 13 & .01 & D \\
\hline October & 4,540 & 14 & 3,520 & 10 & $<.01$ & D \\
\hline November & 4,540 & 18 & 3,880 & 10 & .01 & D \\
\hline December & 4,500 & 11 & 4,260 & 10 & $<.01$ & D \\
\hline
\end{tabular}

${ }^{1}$ A statistically significant trend was defined as having a $p$ value less than or equal to 0.05 .

\section{SUMMARY}

In the lower Arkansas River, the specific conductance increases downstream from a median of about $500 \mu \mathrm{S} / \mathrm{cm}$ near Pueblo to about $3,900 \mu \mathrm{S} / \mathrm{cm}$ at Lamar. The increase is largely attributed to the consumptive use of surface water and ground water for agricultural irrigation and the concomitant increase in the dissolved-solids concentration. The operations of two main-stem reservoirs on the lower Arkansas River (John Martin Reservoir, constructed near Las Animas in 1948, and Pueblo Reservoir, constructed near Pueblo in 1975) have the potential to alter the specific conductance in the Arkansas River by streamflow management. A change in specific conductance could affect the intended use of the water as an agricultural or domestic water supply.

The most notable aspect of the operation of Pueblo Reservoir, in terms of its effect on the historic streamflow regime of the lower Arkansas River, is the Winter Water Storage Program (WWSP). In the winter (November-March), prior to the implementation of the WWSP in 1975, irrigators in the lower Arkansas River Valley generally diverted appropriated Arkansas
River water onto fallow fields to maintain soil moisture. Alternatively, this water could have been stored during the winter and then released to the river for the downstream irrigators to use during times when streamflow was insufficient to meet irrigation needs. However, under Colorado water law, storage of water that is diverted with direct-flow water rights is not permitted. Therefore, the WWSP was created to allow several irrigation canal companies downstream from Pueblo Reservoir to store their direct-flow water in Pueblo Reservoir, John Martin Reservoir, and in several private off-channel reservoirs during winter and to use this water during the crop-growing season. Under the WWSP, winter water storage is allowed from November 15 to March 15. Generally, WWSP water is released from storage at times when streamflow is not large enough to meet irrigation demands. This situation usually occurs in early spring or late summer and autumn. Winter water was stored every year from 1975 to 1994 , except during the 1977-78 winter-storage season. During 1975-94, the median annual volume of water that was stored in Pueblo Reservoir as part of the WWSP was about 42,200 acre-ft. 
Storage of irrigation water in John Martin Reservoir is by agreement between the States of Colorado and Kansas, under the terms of the Arkansas River Compact. The Arkansas River Compact is an agreement between Colorado and Kansas, signed in 1948, which ensures both States will receive their percentage share of Arkansas River flows. Provisions were made in the Compact for the rate of release of stored water, without reference to the volume of stored water assigned to each State. To ensure that each State received its share of stored water, release demands had to be made concurrently. Historically, following the winter-storage period (November-March), reservoir storage usually was drawn down to empty or almost empty very early in the irrigation season, often by the middle of April. Because of the unsatisfactory nature of this operation, a resolution was adopted by the Arkansas River Compact Administration in 1980. This resolution is commonly referred to as the 1980 operating plan. Under the new plan, any water not immediately called for and released to downstream irrigators is stored in separate storage accounts for the States of Colorado and Kansas. Either State can call for the release of its stored water independent of the other. The 1980 operating plan has contributed to increased long-term storage of water in John Martin Reservoir. Prior to 1980 , reservoir storage generally was depleted by the end of April. Since 1980, reservoir storage has increased substantially.

Streamflow and specific-conductance data that were collected at six main-stem Arkansas River sites were evaluated with a step-trend analysis to determine if the operation of Pueblo Reservoir or John Martin Reservoir affected streamflow or specific conductance in the Arkansas River. The nonparametric MannWhitney-Wilcoxon rank-sum test was used for trend analysis. The analysis of streamflow trends was done because streamflow and specific conductance generally are correlated; therefore, changes or trends in specific conductance often can be explained in terms of the associated change or trend in streamflow. Data collected at five streamflow-gaging stations on the lower Arkansas River and at one station on the upper Arkansas River were analyzed for trends. The station in the upper basin was included in the analysis to differentiate between trends in the lower basin that were caused by differences in the quantity or quality of inflow from the upper basin or were caused by reservoir operations in the lower basin. The period of record varied between stations; therefore, trend test results for different stations were not directly compared. Data from the station in the upper basin and from the three stations located between Pueblo Reservoir and John Martin Reservoir were analyzed for trends that may have occurred after 1974, which corresponds to the completion of Pueblo Reservoir in 1975. Data from the two stations located downstream from John Martin Reservoir were analyzed for trends that may have occurred after the implementation of a new reservoir operating plan in 1980.

At the station (07096000) in the upper basin, streamflow increased significantly and specific conductance decreased significantly after 1974 during the low-flow months, January, February, and March. These trends apparently were caused by the increased importation of low-specific-conductance water from the Colorado River Basin into the Arkansas River. The median volume of water imported from the Colorado River Basin into the upper Arkansas River increased from about 62,900 acre-ft/yr in 1964-74 to $103,000 \mathrm{acre}-\mathrm{ft} / \mathrm{yr}$ in $1975-94$. This transmountain water generally is held in storage in upper basin reservoirs as long as possible in order to minimize evaporative losses. However, during winter, stored water may be released to the river and possibly stored farther downstream in Pueblo Reservoir in order to create upper basin storage space for the importation of transmountain water during the coming snowmelt-runoff season. The imported water released to the river in the winter tended to dilute the dissolved-solids concentration of the more mineralized base flow and decreased specific conductance at station 07096000 . Overall, the median specific conductance at station 07096000 decreased about 19 percent from $307 \mu \mathrm{S} / \mathrm{cm}$ in 1964-74 to about $250 \mu \mathrm{S} / \mathrm{cm}$ in 1975-94.

At the three stations located between Pueblo Reservoir and John Martin Reservoir, streamflow and specific conductance primarily were affected by Pueblo Reservoir operations, but changes in the quantity and quality of inflow from the upper basin and from Fountain Creek may have had some effect. At stations 07099400 and 07109500 , which are located 0.4 and 24 mi downstream from Pueblo Reservoir, streamflow generally increased during most months of the growing season and decreased during November through February after 1974. The streamflow trends at these two stations largely were attributed to the operation of the WWSP. 
Specific conductance at station 07099400 changed markedly after the construction of Pueblo Reservoir. Specific conductance at station 07099400 decreased during most months between September and April and increased during the high-flow months, May through August. This trend was caused by the mixing of seasonally low-specific-conductance water with seasonally high-specific-conductance water in Pueblo Reservoir, thus narrowing the annual range in specific conductance in the reservoir outflow. The median specific conductance had a significant decrease of about 21 percent from $625 \mu \mathrm{S} / \mathrm{cm}$ in 1966-74 to $496 \mu \mathrm{S} / \mathrm{cm}$ in $1975-94$. These changes in specific conductance seem to have improved the suitability of the Arkansas River as a domestic water supply in the $8.5-\mathrm{mi}$ reach between Pueblo Reservoir and the diversion point for the St. Charles Mesa Water District.

Few trends, except for increased specific conductance in June, August, and December, were detected in specific conductance at station 07109500 , which is located $24 \mathrm{mi}$ downstream from Pueblo Reservoir. It seems that the combined effects of water storage and mixing in Pueblo Reservoir and the increased inflow of relatively high-specificconductance water from Fountain Creek accounted for the few observed trends. The small amount of specificconductance data may have contributed to the detection of few significant trends.

At station 07124000 , located 120 mi downstream from Pueblo Reservoir, streamflow increased during all months after 1974. Although specific conductance tended to decrease during all months, most monthly trends were not statistically significant at a 95-percent confidence level. However, the median specific conductance decreased significantly from $3,000 \mu \mathrm{S} / \mathrm{cm}$ in $1961-74$ to $2,500 \mu \mathrm{S} / \mathrm{cm}$ in $1975-94$. The increase in streamflow at station 07124000 probably was caused by a combination of factors, including the WWSP and associated changes in seasonal irrigation practices and the increased importation of Colorado River Basin water for irrigation. Prior to the construction of Pueblo Reservoir and the beginning of the WWSP, most winter streamflow was diverted and consumed upstream from station 07124000 . With the adoption of the WWSP and the increased use of transmountain water for irrigation, streamflow at station 07124000 increased significantly. Prior to 1978 , about 14 percent of the annual streamflow at the upstream end of the lower basin flowed past station 07124000 . After 1978, that percentage increased to about 26 percent. Although specific conductance tended to decrease at station 07124000 after 1974 , the water continued to have a high to very high salinity hazard classification for irrigated agriculture.

At the two stations located downstream from John Martin Reservoir, specific conductance was affected by changes in John Martin Reservoir operations, increased reservoir inflow, and a decrease in the specific conductance of the reservoir inflow. All of these factors resulted in increased streamflow and decreased specific conductance downstream from the reservoir. At stations 07130500 and 07133000 , located 0.2 and $20 \mathrm{mi}$ downstream from John Martin Reservoir, specific conductance decreased significantly during most months from September through April and had no significant changes during May through August. The median specific conductance at station 07130500 decreased significantly from $2,700 \mu \mathrm{S} / \mathrm{cm}$ in $1955-79$ to $2,260 \mu \mathrm{S} / \mathrm{cm}$ in $1980-94$. Similarly, the median specific conductance at station 07133000 decreased significantly from $4,000 \mu \mathrm{S} / \mathrm{cm}$ in $1964-79$ to $3,510 \mu \mathrm{S} / \mathrm{cm}$ in $1980-94$. These trends were very similar to the trends that were observed immediately downstream from Pueblo Reservoir and largely were attributable to increased storage and increased mixing of seasonally lowand seasonally high-specific-conductance water in John Martin Reservoir. These factors tended to increase the minimum specific conductance and decrease the maximum specific conductance in the reservoir outflow. Overall, the changes in specific conductance that occurred at stations 07130500 and 07133000 did not change the salinity-hazard classification of the water for irrigated agriculture; water at both stations retained its high to very high salinityhazard classification.

\section{REFERENCES CITED}

Abbott, P.O., 1985, Description of water-systems operations in the Arkansas River Basin, Colorado: U.S. Geological Survey Water-Resources Investigations Report 85-4092, 67 p.

Arkansas River Compact Administration, 1980, Thirtysecond annual report: Lamar, Colorado, $50 \mathrm{p}$.

Bradley, J.V., 1968, Distribution-free statistical tests: Englewood Cliffs, New Jersey, Prentice-Hall, 388 p. 
Cain, Doug, 1985, Quality of the Arkansas River and irrigation-return flows in the lower Arkansas River Valley, Colorado: U.S. Geological Survey WaterResources Investigations Report 84-4273, 85 p.

1987, Relations of specific conductance to streamflow and selected water-quality characteristics of the Arkansas River Basin, Colorado: U.S. Geological Survey Water-Resources Investigations Report 87-4041, 93 p.

Edelmann, Patrick, and Cain, Doug, 1985, Sources of water and nitrogen to the Widefield aquifer, southwestern E1 Paso County, Colorado: U.S. Geological Survey Water-Resources Investigations Report 85-4162, $81 \mathrm{p}$.

Helsel, D.R., and Hirsch, R.M., 1988, Discussion of "Applicability of the t-test for detecting trends in water-quality variables," by R.H. Montgomery and J.C. Loftis: Water Resources Bulletin, v. 24, p. 201-204.

1992, Statistical methods in water resources: Amsterdam, Elsevier Science Publishers, 529 p.

Hurr, R.T., and Moore, J.E., 1972, Hydrogeologic characteristics of the valley-fill aquifer in the Arkansas River Valley, Bent County, Colorado: U.S. Geological Survey Hydrologic Investigations Atlas HA-461, scale $1: 62,500,2$ sheets.

Lewis, M.E., and Edelmann, Patrick, 1994, Physical, chemical, and biological characteristics of Pueblo Reservoir, Colorado, 1985-89: U.S. Geological Survey WaterResources Investigations Report 94-4097, 71 p.

Miles, D.L., 1977, Salinity in the Arkansas Valley of Colorado: U.S. Environmental Protection Agency and Colorado State University, Interagency Agreement, EPA-IAG-D4-0544, 80 p.

Nelson, G.A., Hurr, R.T., and Moore, J.E., 1989a, Hydrogeologic characteristics of the valley-fill aquifer in the Arkansas River Valley, Prowers County, Colorado: U.S. Geological Survey Open-File Report 89-254, scale $1: 62,500,3$ sheets.

$-1989 \mathrm{~b}$, Hydrogeologic characteristics of the valleyfill aquifer in the Arkansas River Valley, Crowley and Otero County, Colorado: U.S. Geological Survey Open-File Report 89-255, scale 1:62,500, 3 sheets.

1989c, Hydrogeologic characteristics of the valley-fill aquifer in the Arkansas River Valley, Pueblo County, Colorado: U.S. Geological Survey Open-File Report 89-256, scale 1:62,500, 3 sheets.

Richards, L.A., ed., 1954, Diagnosis and improvement of saline and alkali soils: U.S. Department of Agriculture Handbook 60, $160 \mathrm{p}$.
Searcy, J.K., and Hardman, C.H., 1960, Double-mass curves; manual of hydrology, part 1, general surfacewater techniques: U.S. Geological Survey WaterSupply Paper 1541-B, 65 p.

Taylor, O.J., and Luckey, R.R., 1974, Water-management studies of a stream-aquifer system, Arkansas River Valley, Colorado: Ground Water, v. 12, no. 1, p. 22-38.

U.S. Department of the Interior, 1994, Salinity update: Denver, Bureau of Reclamation, Colorado River Salinity Program Coordinator, $17 \mathrm{p}$. -1996, Annual operating plans-FryingpanArkansas Project: $16 \mathrm{p}$.

U.S. Environmental Protection Agency, 1986, National secondary drinking-water regulations, part 143, section 143.3: Code of Federal Regulations, Title 40, parts 100-149, p. 587-590.

U.S. Geological Survey, 1959, Quality of surface waters of the United States, 1955: U.S. Geological Survey Water-Supply Paper 1402, parts 7 and 8, 539 p. 1960 , Quality of surface waters of the United States, 1956: U.S. Geological Survey Water-Supply Paper 1452, parts 7 and 8, $469 \mathrm{p}$. 1961, Quality of surface waters of the United States, 1957: U.S. Geological Survey Water-Supply Paper 1522, parts 7 and 8, $499 \mathrm{p}$. 1962-65, Surface water records of Colorado (published annually).

1963a, Chemical analyses of surface waters in Colorado, October 1959 to September 1962: 56 p. $1963 \mathrm{~b}$, Quality of surface waters of the United States, 1958: U.S. Geological Survey Water-Supply Paper 1573, parts 7 and 8, $588 \mathrm{p}$.

1964, Quality of surface waters in Colorado, October 1962 to September 1963: 83 p.

1965a, Water quality records in Colorado, 1964 : $84 \mathrm{p}$.

$1965 b$, Quality of surface waters of the United States, 1959: U.S. Geological Survey Water-Supply Paper 1644, parts 7 and 8, $507 \mathrm{p}$. 1966-75a, Water-resources data for Coloradopt. 1, Surface water records (published annually). 1966-75b, Water-resources data for Coloradopt. 2, Water quality records (published annually).

1976-95, Water resources data, Colorado, water years 1975-94-v. 1: U.S. Geological Survey WaterData Reports CO-75-1 to CO-94-1 (published annually). 